361

U4

$1911 \mathrm{c}$ 


$$
\text { ช。 }
$$




$$
\text { - }
$$





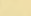





\section{ALASKAN SEAL FISHERIES}

\section{HEARINGS}

BEFORE THE

COMMITTEE ON CONSERVATION OF NATIONAL RESOURCES, UNITED STATES SENATE

ON THE BILL

\section{S. 9959}

TO AMEND AN ACT ENTITLED "AN ACT TO PROTECT THE SEAL FISHERIES OF ALASKA, AND FOR OTHER PURPOSES," APPROVED APRIL 21, 1910

No. 1 


$$
\begin{aligned}
& 5+36^{1} \\
& 4 \times 10
\end{aligned}
$$

COMMITTEE ON CONSERVATION OF NATIONAL RESOURCES.

UNITED STATES SENATE.

JOSEPH M. DIXON, of Montana (chairman).

CLARENCE D. CLARK, of Wyoming.

ALBERT J. BEVERIDGE, of Indiana.

WELDON B. HEYBURN, of Idaho.

CHARLES DICK, of Ohio.

FRANK O. BRIGGS, of New Jersey.

SIMON GUGGENHEIM, of Colorado
WESLEY L. JONES, of Washington.

FRANCIS G. NEWLANDS, of Nevada.

LEE S. OVERMAN, of North Carolina.

JOHN H. BANKHEAD, of Alabama.

ELLISON D. SMITH, of South Carolina.

CLARENCE WAYLAND WATSON, of West Virginia.

MILES TAYLOR, Cletk.

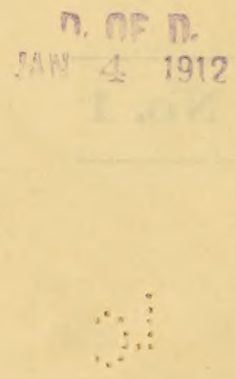




\title{
ALASKAN SEAL FISHERIES.
}

\author{
SAtUrday, February 4, 1911.
}

The committee met at $10.30 \mathrm{a} . \mathrm{m}$.

Present, Senators Dixon (chairman), Clark of Wyoming, Dillingham, Heyburn, Jones, Smith of South Carolina, and Watson.

Hon. Charles Nagel, Secretary of Commerce and Labor, appeared.

\section{OPENING STATEMENT BY THE CHAIRMAN.}

The Chairman (Senator Dixon). Gentlemen, we do not have a quorum of the committee present. It is almost impossible at this stage of the session to get a full meeting of a large committee, unless something of tremendous importance comes up, and on Saturday morning it is especially hard. I have called the committee together at the earnest solicitation of some gentlemen for a hearing on the bill of Senator Nelson, introduced last January, to declare a five-year absolute closed season. I think there is some difference of opinion as to what the bill passed a year ago really meant; whether it really was intended to provide an absolute closed season or not, or whether discretion was to be given to the department to go ahead with the killing. Prof. Elliott and Dr. Hornaday and Mr. Seymour are the gentlemen who have communicated with me specially regarding this.

As I understand it, vou gentlemen have some testimony regarding conditions on the islands, the killing during the last season, and the fact, as I understand it, that a large part of the killing was of female seals, and that the bulls had been killed down to a condition where the old ones are almost impotent. As I recall it, this is the general line of the charges. Whom do you wish to have testify, Mr. Seymour? You are the attorney for the Camp Fire Club.

STATEMENT OF MR. JULIUS H. SEYMOUR, OF NEW YORK, REPRESENTING THE CAMP FIRE CLUB OF AMERICA.

Mr. Seymour. Mr. Chairman and gentlemen, I might say in opening that our purpose is to discuss the merits of this Senate bill No. 9959 , as to whether or not now, under the present conditions, no matter what has gone by in the past, there should be a closed season. I am sorry that the Secretary of Commerce and Labor did not stay, as he was in the room; but whatever we do or say, it will be just the same as if he were here, and he will find that this will be confined simply to a logical and reasonable discussion of this question.

Senator Heyburn. Are you in favor of a closed season?

Mr. Seymour. We are decidedly in favor of a closed season, and as to that I would like to call on Dr. Hornaday, who is as well versed 
in this subject, probably, as anybody living. He will say a few words in reference to why we believe there should be a closed season. The Chatrman. We will be glad to hear from Dr. Hornaday.

\section{STATEMENT OF DR. WILLIAM T. HORNADAY, OF NEW YORK CITY, CHAIRMAN COMMITTEE ON GAME-PROTECTION LEGIS- LATION OF THE CAMP FIRE CLUB OF AMERICA.}

Dr. Hornaday. Mr. Chairman, and gentlemen of the committee, I will try to be very brief, because I realize the many necessities of the situation.

First let me call your attention to the fact that in our original request to Congress for action in this matter our first specification was for a cessation of the laws existing; second, a 10-year closed season; third, the negotiation of treaties for the suppression of pelagic sealing. We reached these conclusions, gentlemen, after a very long and careful deliberation and examination of all the facts and all the records bearing on the case. These decisions were not reached hastily. We considered the matter from a financial standpoint, from a political standpoint, and from a zoological standpoint.

I want to speak for a moment on the zoological aspects of this case. My colleagues will take care of the political side - that is, the treaty side. I will only add for my part that on the $22 \mathrm{~d}$ of last March we addressed to Secretary Knox a specific written request, asking him, begging him, to renew the propositions contained in what is familiarly known as the Hay-Durand treaty, and we are credibly informed that that is the treaty that is now under consideration and has actually been signed by somebody. That is one feature of what we thought was very necessary, and which we still think necessary, but that is only one item of what we regard as a very necessary program. You gentlemen know quite as well as I do that this situation presents some extraordinarily difficult aspects. There never has been a conservation question before this Government which has been so complicated, so hedged in with difficulties, so fertile of rebuffs and disputes as this. The whole resources of the United States Government during the 12 years past have not been able to make one iota of progress until your bill was finally passed by Congress.

Now, we will assume, if you please, that this treaty is about to be ratified and that it will be ratified. We are praying that it will be ratified. It is a very important and necessary step, but, even if it is, there are two other nations to be considered, Japan and Russia, and it is impossible for anybody to say in advance what they will do. It is impossible for anybody to say whether they are willing to negotiate treaties while we go on killing on those islands. We can not tell what will happen. Let us take no chances on this matter for the sake of the few paltry dollars that can from year to year be obtained from this killing. The future stake is too great.

Let us now take up the zoological aspect of the case, which I had particularly in mind. You see on these is ands the remnant of a mighty marine life. It is merely a remnant in comparison to the millions existing years ago, and it is no exaggeration to call it that. We know the process that has been going on The killing of seals on land and the killing of seals at sea by the pelagic sealers has gone on until the fur-seal life has been drained to the very dregs. I don't think there is any room for argument on that point. 
The Cimarman. What is your estimate, Dr. H maday, of the number of seals left?

Dr. IORNADAY. I can only make a guess at it by the number available for killing every year, and I think that affords an excellent index of the condition of that herd. I know that the Bureau of Fisheries estimates or counts that there are 50,000 breeding females there. Now, if there are 50,000 breeding females, why is it there are only 14,000 seals killed each year. It is my opinion that there are about 30,000 seals left there; 30,000 breeding seals and a small margin of male life. This opinion is based on the actual killing that takes place and the absolute knowledge that of that killing a great deal consists of seal life that formerly was not touched at all. The limit of size has steadily been lowered; the seals killed are getting shorter and shorter every year. That means only one thing. I think if there are 50,000 breeding seals it would be possible to get 30,000 a year, instead of only 14,000 .

Senator Heyburn. You refer to those killed on land; you do not take into account those killed in the water.

Dr. Honnaday. No; I am not speaking of that at present. Here is our opportunity to recuperate a desolated species. I want to read three or four sentences from an article in the last number of the Popular Science Monthly by a gentleman who is no less a man than the chairman of the advisory board of the fur-seal service, President David Starr Jordan, of Stanford University. I think that both sides can agree that we can afford to bring forward his testimony in regard to this question. 'These views are important, gentlemen, in making a decision on this broad case and it impinges directly on this bill.

The last 30 years have seen the period of greatest activity in the study of biology. Among other matters, we have seen the rise of definite knowledge of the process of heredity and its application to the formation and improvement of races of men and animals. From our

With men, as with animals, "Like the seed is the harvest." In every vicissitude of race of men or of breed of animals, it is always those who are left who determine what the future shall be.

All progress in whatever direction is conditioned on selective breeding. There is no permanent advance not dependent on advance in the type of parenthood. There is no decline except that arising from breeding from the second-best instead of the best.

* $\quad * \quad * \quad * \quad * \quad * \quad * \quad *$

We have now to consider only a single factor. In science, this factor is known as "reversal of selection." "Send forth the best ye breed!"

The decline of a people can have but one cause, the decline in the type from which it draws its sires. A herd of cattle can degenerate in no other way than this, and a race of men is under the same laws.

* * * * * * * * * * * * * * * * * *

The survival of the fittest in the struggle for existence is the primal moving cause of race progress and of race changes. In the red stress of human history, this natural process of selection is sometimes reversed. A reversal of selection is the beginning of degradation. It is degradation itself.

In times of peace there is no slaughter of the strong, no sacrifice of the courageous. In the peaceful struggle for existence there is a premium placed on these virtues. The virile and the brave survive. The idle, weak, and dissipated go to the wall.

And all laws of probabilities and of averages are subject to a still higher law, the primal law of biology, which no cross-current of life can overrule or modify. Like the seed is the harvest. 
Here is the situat ion to-day. Can you or can any man take a desolated species that has got down into the slough of despond and go on killing its males, 95 per cent of them every year, and expect that the fittest males will survive to do the breeding? I say it can not be done. 'The moment man interferes with a wild species, deterioration begins. The conditions between wild species and domestie species are highly diflerent. They have always been so and they always will be. There is not a case on record where man has successfully stepped in to regulate the breeding of a wild spereies with suceessful results.

Let us take a few cases in point. Take the antelope in the nine ivestern States which still contain prong-horned antelope. I little while ago that species had got down to a very low point. The men of the Uirest came to see that unless something was done to regulate it the species was doomed to disappear forever. Did they forbid the killing of all but 5 per cent of the male antelopes? No, they did not. They knew it would not do to interfere with those herds in that way. They passed laws that not a single antelope should be killed, and today in those nine States which still contain antelope the law is universally for a long closed season. In most of the States it is five years. You can not go out there and kill a male antelope without being fined in most of the States $\$ 500$. The males can be picked out by hunters. The females have no horns, and if they felt it was wise to kill off 95 per cent of the males, it would be easy enough to pick them out and do it. That is how the States regard it, and the same laws apply to-day on the Pribilof Islands.

Take the case of the United States Government. Let us see how the Govermment regards this question. The caribou on the Alaskan Peninsula were threatened with extinction-Grant's caribou. Did the Government pass a regulation that only males should be killed? No, indeed; they said all killing must stop on the Alaskan Peninsula. They declared a closed season for 10 years, and the same was done in regard to the caribou on the Kanai Peninsula. That is the way the Government regards it.

Take the case of the elk in the Yellowstone Park. There are thousands of elk in the Yellowstone Park and many of them males. Does the Government permit males to be killed there for the good of the herd? No, indeed; not a single male may be killed on Gorernment territory. Outside it is different. The big males are culled ofl by the hunters during the hunting season; they are culled out each year. The fittest to survive are the ones first killed. What is the result?

Senator IIEyblrx. Didn't you state in your former hearing before us that the seals paired off and mated?

Dr. Hornaday. The seal is a highly polygamous animal.

Senator Heyburn. Some one made that statement.

Dr. Honnadar. Yes, I remember it; but each male has his own harem.

In the case of the elk in the Yellowstone Park the males that are fittest to survive are killed by the hunters, and if you visit these herds to-day you can see the result in the deterioration of the stock. It is a difficult matter for a humter to go out there now and find a male with a pair of antlers such as they found 25 years ago. The antlers are steadily growing smaller. 
Take the red deer of Europe, for illustration. Two hundred years ago the red deer of Germany and Humgary were magnificent animals. They had antlers verging close onto the size of our best elk to-day. Go into the old castles of Germany and IInngary where the owners had a taste for hunting and saring antlers and you will find scores of pairs of antlers such as can not be found to-day anywhere in the world on the living animal. The animal, physically, has steadily gone down. Why? Because the best males have been picked out and killed. That is the reason-nothing else in the world. I tell you, gentlemen, interfere with the laws of nature by killing the imales and down goes the physical character of the species.

The same is true of the moose to-day in Maine.

Take the ease of the wood duck in the State of New York, to come closer home. The wood duck had reached a very low point. Sportsmen very grudgingly conceded that fact, and very grudgingly agreed to a law for its preservation. Did they except 95 per cent of the males? By no means. They put on an absolute closed-season law in the State of New York, and yet the males are as easily distinguished from females as male deer are from female deer.

Coming down to fur seals, take the Russian example. We must treat things from history. We, certainly, as an enlightened people, do not need to experience everything ourselves before we act. The Russians were very greedy in the matter of killing seals. They were asked, long before they did it, to inaugurate a closed seasenn." They refused, admitting it would be a good thing, but refused, just hi main strength as it were. You know what happened. The scal.s went down t; such a point that they were obliged to put on a closed season for 10 years. It will be said in answer to that that the Russians killed both females and males. So they did.

Mr. ElirotT. You are mistaken, Dr. Hornaday; the Russians never drove from the breeding grounds-never, since 1802 - they respected those breeding grounds better even than we have done.

Dr. IIORxidor. I am glat to hear that; I did not so understand it.

Now, gentlemen, this is the conclusion of my point. We claim as a zoological proposition that the way to bring up the seals of the Pribilof Islands to a point where the industry of seal killing will amount to something, will be worthy of serious consideration, will bring into our 'Treasury something worth having, is to give the herds am ibsolute rest for five vears. If rou, as business men, owned those seals, I will guarantee that that is what you would do. That is what I certainly would do. I would not any more go on with killing 95 per cent if those males than I would dig up seed potatoes in my fields and eat them because I thought it was a long time until the harrest. That is the only way to bring up a species.

The law of nature which requires that man shall keep his hamels off a decimated species is perfectly plain. There is no getting around it: it is a fixed fact, and I have been profoundly sumprised that certain distinguished men, otherwise good zoologists, have taken the ground and stated again and again that 95 per cent of the male seals on these islands need to be killed for the good of the herd. They do not. The realson why they do not need to be killed is this: Let those seals alone and the strongest and the ablest bulls will do the breeding. That is all there is to it. If rou kill 95 per cent of the males, rou are pretty certain to kill 95 per cent of the best bulls. You can not tell 
when rou kill s-rear-olds how those animals are going to develop) when 6 years old. It is impossible, and the result is that just so sure as we go on killing 95 per cent of these mate seals to-day, we will have left to do the breeding a lot of second and third rate males.

If rou let nature alone the bigerest and strongest bulls will drive the weaker ones to one side, and they will do the breeding, and that is what brings up a species and heeps it up to the hioghest standard. It seems to me that that is such a plain business proposition that there is no possible gainsaying it. No one needs to be a scientific man to judge of that. It is just as plain as print, and, moreover, we don't know what is enoinge to happen to these seals. Now is the time to stop killing for five years, and (amada has expressed her willingness to abide by that decision if we do it. That will give us time to ascertain what can be clone with Japan and with Russia.

Senator Heyburx. You refer to the killing in the water?

Dr. HonnADAx. I refer to the killing on land.

Senator IIExBCRx. We can control the killing on land ourselves.

Dr. HorNADAY. That is what I am asking you to do. I am speaking wholly of killing on land, because we all agree that killing in the water means the killing of a great many females and must be stopped or the whole industry will be ruined and the fur seal lost. We all agree upon that, and when this committee reported farorably on the bill passed last year we thought the matter was settled and that we were to have a closed season. I am sure some of the members of this committee thought so too.

Senator HEYBURN. I thought so.

The ('mammax. I thought so, too, and I believe many of the Senators thought so.

Senator IIExBCRN. I never believed in permitting the killing upon land at all.

Dr. Hornaday. And it came to us of the Camp Fire Club as a mighty shock when we learned on the 1st of last May that killing was to go on.

The Charrman. I think the universal feeling was that it was going to be a closed season.

Senator Clark of Wyoming. I don't think anybody thought otherwise.

Dr. Hornadiy. The whole people of the United States thought that was settled and that there was to be no further killing. The President signed that bill on the 21st of April, and on the 1st of May the Commissioner of Fisheries, Mr. Bowers, announced, and it was printed in the Seattle Post-Intelligencer, that they were going on with the killing again this season, but he qualified it by saying: "There will be no wholesale killing, but we think they should be killed for the good of the herd."

And what did they do? They killed 12,920 seals, in spite of our protest. We protested to the Secretary of Commerce and Labor in the strongest terms, that he might be given notice in time of what he was doing. What was the result? He paid not the slightest attention to it so far as refraining from his intended policy was concerned.

The Charrman. Now I want to suggst to the committee, inasmuch as the department officials are here, including Mr. Lembkey, who was in charge of the Pribilof killing last year, that we hear from him. 
STATENENT OF MR. WALTER I. LEMBKEY, AGENT IN CHARGE OF SEAL FISHERIES OF ALASKA, IN THE DEPARTMENT OF COMMERCE AND LABOP.

The Cimarman. Mr. Lembley, what is your official status and title?

Mr. Lembier. My official title, Mr. Chairman, is agent in charge of seal fisheries of Alaska, in the Department of Commerce and Labor.

The Chammax. You were in charge of the Pribilof Islands and the killing there during the past season?

Mr. LeabKey. Ies, sir; I have general supervision over that work.

The Charman. And you had been there prior to that time?

Mr. LembKey. I have been there for 12 years now.

The Chairman. Now, Mr. Lembkey, go ahead and tell the committee what the Department of Commerce and Labor did during the past year in the matter of killing seals; the number you killed, and the general conditions. Just tell the whole story and why.

Senator Herburn. And the disposition made of the seals.

The Chamman. Yes, and the disposition made of the seals.

Mr. LevBKEY. As a matter of fact, the killing on the islands was carried on during last summer in the same manner, practically, as it had been carried on during the period of the lessee of the sealing right. That is to say, before any killing was allowed in the spring a certain number of the finest of the young males were reserved for breeding purposes, and were marked so as to be readily discernible during the season.

Senator Heyburs. How do you mark them?

Mr. LemвкеY. We mark them by clipping the fur off the heads with sheep shears.

Senator CLark of Wyoming. How long does that last?

Mr. Lembkey. That lasts during the entire season.

Q. You can not recognize that seal the next season?-A. You can not recognize the seal the next season, but after this so-called breed reserve has been secured killing for skins takes place. No skins were to be killed under 5 pounds in weight; no seals were to be killed that had skins weighing orer $\$ \frac{1}{2}$ pounds. All between those weights, with the exception of those marked for the breed reserve, were killed. Drives were made over the killing grounds as often as in the judgment of the native foreman in charge of the seal gang the drive would be justified. There they were carefully gone over; this reserve for breeding was carefully guarded from slaughter.

The Chammax. What percentage did you reserve from killing of the males?

Mr. LeMBrey. It is almost impossible to state what percentage of the whole number we did reserve, because we do not know, for instance, with any degree of accuracy how many 3 -year-olds are in existence. We can not drive these animals into a corral and count them over and from this take a certain percentage. As a matter of fact, some of these animals are always in the water or they haul out in inaccessible places where they can not be counted.

Q. Approximately what percentage?-A. Approximately we observed, I should say, 20 per cent of the 3 -year-olds in existence; from 15 to 20 per cent. Not all the killable seals haul out during the summer at any one time so they can be driven. That you may understand what I mean by "haul," I will say that they come on land, so 
that they may gather into drives and be brought to the village; but of those that did haul out during the summer in 1909, 66 per cent were killed and 33 per cent were released.

Senator CLARK, of Troming. Those were all yearlings?

Mr. LembkeY. All the killable seals of those driven.

Q. But they were all yearlings !- A. They were all yearlings; no full-orown bulls. Those driven were immature seals.

The Chumman. You mean male seals?

Mr. LEMBKEY. I mean male seals; res, sir; and of those driven 66 per cent were killed for skins and 33 per cent, or one-third, were released.

Q. That was under the old contract system?-A. Yes, sir. Now under this new system we kill about 68 instead of 66 per cent, the condition being that in our opinion the seals did not for some climatic reason haul out on land in the same proportions as ther did cluring the preceding year. Now we have a large number of immature young males past the age of clubbing growing up to supplant those old bulls now on the rookeries, which of course are dying off. We are releasing the number each year to keep up that breeding reserve, and we do feel that the conditions are demonstrated which will indefinitely perpetuate this seal species.

The Chamman. How many did you kill last year?

Mr. Lembkey. We killed 12,920.

Q. How many had the old fur company killed the year before?A. They killed 14,000 and something.

Q. What was the youngest seal you killed; what age?-A. Two years old.

Q. The statement has been made that it is hardly possible to distinguish the male and the female at that age?-A. At 2 years old?

Q. Yes; what is your opinion?-A. There is considerable difficulty in distinguishing the young males and females. There is considerable difficulty in distinguishing the male and the female yearling. They are both of the same size and general formation. It is almost impossible for anybody not an expert to pick them out and distinguish between them, and it is rather difficult, even for an expert; but of the 2-year-olds the females are not on the hauling grounds; they are on the breeding rookeries for their initial impregnation. The 2-year-old males, on the other hand, are on the hauling out grounds.

Q. In the killing last year, did you kill any female seals?-A. Not to my knowledge, sir. I had general supervision, as I say, over the work on both islands, but, being back and forth from day to day, I was not present at every killing and could not, of course, be; but I carefully interogated this moning Dr. Judge, who had charge of the kilhing in St. Prul, and Maj. (lark, who had charge on St. George, as to whether any female seals ha! been kilied during the past season, fo their knowledge, and they stated that none had been lilled.

Senotor ClARK of Wyoming. May I ask a question?

The ('manmax. ('ortainly. I want arerybody to ask such questions as they desire, which will throw light on this subject.

Senetor ('LARK of Wroming. Were rou present at the hearing on this bill last year-the bill that was passed by Congress?

Mr. Lenbirey. Yes, sir; I was present at one hearing:

Senator ('LAR of frroming. I understand that that bill was pareed at the solicitation of the Depurtment of Commerce and Labor 
on the theory that if relief was not granted immerliately it would be necessary to reenter into the contract with the company which has the privilege of killing at that time, and the complaint made, or I have understood that to be one of the reasons why that company should not be given the contract again, was because their method of operation was such that the herds were rapidly becoming extinct, and it was necessary to make some zeneral change, which I understool at that time was to be a closed season. Now, it seems from your statement, notwithstanding the fact that the bill was passed. for the sole purpose of changing that method of handling these seals, they have been handled in exactly the same way they were before.

Mr. Lembrey. I of course do not know what communication the homorable Secretary of ('ommerce and Labor had with the committee. I do know this, however, that the question of the renewal of the lease was a legal point more than anything else; that the law was such that if it were not amended within a certain time-that is to say, before the 1st of April, 1910-it would be mandatory upon the Secretary of Commerce and Labor to renew that lease for a further period of 20 years.

Semator Cistik of Wyoming. Perhaps it would be proper for me to ask this question, which occurs to me at this time: So far as the seal herd itself is concerned we have not made a bit of advance by the bill which we took up at the earnest solicitation of the Secretary of ('ommerce and Labor last year and passed; things have been going on in the same way?

The Charuin. I want to ask Mr. Lembley if there was danger of exterminating the seal herd under the contract system, why does not the same condition obtain when the Govemment does the killing?

Mr. Lenbrer. I do not believe, Mr. Chairman, that any statement has ever been made by any person in the Department of Commeree and Labor or in the Goreriment that the methorls practiced on land have resulted in the climinution of a single life from the herd.

Q. Does it result in deterioration of the species from the standpoint of Dr. Hornaday - that the indiscriminate killing of the male, of the killing of the strone, virile male, as well as the weakling, deteriorates the species?-A. No, sir; I don't think so. In the first place, the reservation of males for breeding which we now make is made from the best of the species, the roungest, the largest, the ablest, and the? strongest examples of their hind coming to the islands at the first of the season. They are the stronger swimmers, and therefore get theie first; they are beautiful animals, perfect in every respect. ()f these this reservation for breeding is made, and it can not be said under. those circumstances that we kill the best and reserve only the poorest. because exactly the opposite is the case.

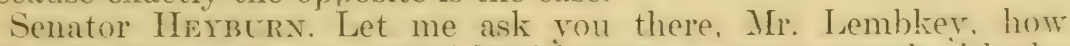
many seals were born on the island last year, as compared with the same period under the leasing system?

Mr. Lambier. I have estimated that a decrease of 5 per cent occurred diring the past rear. The exact number of females is about 14,000 , I think, something like that; but, as a matter of fact, the decrease did not occur that is believed by some.

Now, then, if all the males were allowed to come upon the brealin. grounds and none were lilled, it is my belief, based upon actual obserration, that the strongest males obtain positions among the coms and they are combatted by other males which desire to get stations 
(1) to oust them from their preemptions and drive them off and take their harems, and that, as a matter of fact, from the incessant fighting monger these males that have succeeded in obtaining a place on the rookery, their vigor and vitality is so worm out through excessive fighting that sooner or later their places are taken by seconcl-grade males that theretofore have not been able to obtain a foothold. That is my actual observation.

The Cumbmax. What did it cost the Government to do the killing and selling and the superintendling of the killing, during the past season?

Mr. Lembrer. Outside of the buying of the plant it cost about $\$ 23,000$ in round numbers.

Q. What did you pay for the plant under the appropriation?-A. In the neighborhood of $\$ 63,000$, including merchandise and everything.

Q. How much of that was merchandise, do you remember?-A. If I remember correctly, about $\$ 12,000$; about $\$ 51,000$ was paid for the old plant of the fur company.

Mr. Marshall Mclean, of New York City. Mr. Chairman, may I ask a question?

The Chairman. Certainly.

Mr. McLean. If, as you say, there was a reduction of 5 per cent in the births on the island this year, is it fair to assume that only about 5 per cent of the females were killed by the pelagic sealers?

Mr. LeMbier. No; no conclusion of that kind can be arrived at. It would simply mean that the loss might be due to pelagic sealing. In other words, the increment equaled 95 per cent of the loss. That is the way to put it.

Q. I was just going to ask what percentage of the females do you figure were lost or killed through the operations of the pelagic sealers.-A. Oh, various estimates are made. I believe that killing in Bering Sea consists of at least 75 per cent of the females; on the west coast probably below that; but that is a conservative estimate.

Q. Can you give us any figures as to the pelagic sealing catch of last season?-A. I can not; no, sir.

Prof. ElliotT. Sixteen thousand skins; 13,000 by our people on the islands and 16,000 by the other agents or pelagic hunters.

Mr. McLean. Assuming those figures are correct, about 75 per cent would be females, as I understand it?

Mr. LembKer. Yes, of course; I could assume from that hypothesis that 75 per cent of the pelagic catch is from that, but, as a matter of fact, it does not seem to work out.

Prof. ElliotT. Some of your reserve males are killed there, too, I suppose?

Mr. Lembkey. Prof. Elliott, I am addressing the committee at the present time; but I suppose some of them are killed, too.

Mr. Seymocr. May I ask a question?

The Cimamax. You are a member of the Camp Fire Club?

Mr. Seymour. I am a member of the legislative committee of the Camp Fire Club of America.

Q. I ask Mr. Lembkey whether, under the present circumstances, he would be in favor of this bill for a closed season of five years?

Mr. Lembkey. Under the present circumstances, and disregarding the information which I have just received here to the effect that 
a treaty is being concluded, I should say that there was absolutely no merit in the bill whatever.

Q. For what beason, Mr. Lembkey?-A. The reason is simply this: That the caluse of the loss in seal life is the lilling of females at sea. There is no one who can successfully maintain the proposition that the killing on land has ever caused the loss of a single life, excent those among the surplus males, which are not necessary for breeding purposes, and for that reason I do not see that the stopping of killing on land would in any way go to the merits of the situation or to the root of the matter. If you were to stop killing on land, you would leare nearly that many moreseals for the hunters in the sea to kill. You would encourage sea killing by stopping land killing, because you would give the sea killers so many more seals with which to augment their catch. That seems periectly apparent, and unless it can be proven that the killing on land is of such a nature as toprevent the birth of seals that otherwise would have been born, you can not prove that the stoppage of land killing will in any way relieve this situation.

The Cummux. Then it is your contention that if you did not kill this excess number of males that that larger number would be a greater attraction to the pelagic sealers?

irr. Lembker. Lndoubtedly. Now, then, it seems to me that it is necessary--since this matter has been gone into, I presume I may discuss this feature of it -it will be necessary to obtain at least Japanese concurrence in any proposition of this character, for she operates possibly 35 pelagic sealer's, as against last rear 5 , I believe, Canadian vessels.

Q. Were those the cnly ressels engaged last year in pelagic sealing, 5 Canadian and 35 Japanese?-A. To my knowledge, yes, sir; and to the knowledge of any one that has been in that portion of the country.

Senator Joxes. How does that compare with the preceding year?

Mr. LEMBKEY. I think there were more Japanese.

The CHArmax. What about the allegation that a good many of the Japanese sealers are really owned by Americans and merely fly the Japanese flag and have Japanese crews in order to get a status under international law?

Mr. Lembrey. The charge was male some years ago, or the rumor was inrestigated, you might say, to the eflect that a United States consul in Japan by the name of Kane, who was married to a Japanese woman, by the way, had stock in companies which owned quite al number of the Japanese pelagic ships. A request was made to the State Department to investigate this rumor, and a reply was received from the State Department to the effect that ther could obtain no information whatever whirh would lead them to believe that Mr. Kane was in any way connected with the pelagic sealing business. Outside of that one instance I have nerer heard of an American owning stock in the Japanese fleet. I have heard persistent rumors to the effect that Americans had stock in the Canadian fleet-the Victoria Sealing Co. (Ltd.)-but outside of those lumors I was nerer able to get any further.

Q. What did you get for the sealskins sold by the Gorermment last year? - A. If I remember correctly, ther netted $\$ 403,000$, and the net revenue to the Government was $\$ 1 \$ 3,000$ more than the year previous under the old leasing system. 
The ('marmax. What was the amount?- $1.8403,000$ was the amount of the gross returns, as I remember.

'The Cuanm.x. The gross charges for killing amounted to $\$ \$ 3,000$ ?

d. Dr. Evermann states to me that the $\$ 403,000$ was net returns, and not gross.

(2. Then against that you charge up) $\$ 83,000$ for the balance of the killing by the Government - - I. I es, sir; we do that; subtract $\$ 153,000$, we will say, and aceording to that hasty estimate we would get $\$ 167,000$ more this year in revenue than we did last year.

Q. What is the total net revenue, deducting the cost of operation?A. It would be $\$ 403,000$ less $\$ 83,000-\$ 320,000$.

Q. Then, what did it cost the Government last year to police the islands with revenue cutters?- -1 . There were three cutters on patrol. The estimated cost of maintaining this cutter patrol is figured-and a very liberal estimate is made, at that of, say, $\$ 10,000$ a ressel during the summer. 'That would make, therefore, we will say, $\$ 30,000$ as the cost of the patrol. Of course, this does not inclucie the paring of the officers and men, because they are always under pay hi the Government, and the Government is not put to inv additional cxpense in mantaining this patrol, except perhaps the extra coal and water they would consume.

Senator C'LARK, of IVyoming. It takes three extra ressels, does it not: the fact of theiv having to be there requires us to have three additional vessels?

Mr. Lembirer. No, sir; I don't think so.

Q. Them as a matter of fact, the Govermment is extravagant in supporting three cutters not necessary for the service, except as they are used un there?- $\Lambda$. I don't think you could draw that conclusion, sir, for the reason that a cutter is neoded in emergencies. She might lie in port wating for some situation to arise which would require her service; she might lie there for months and then perhaps she would have to render assistance to wreckis almost continuously for a short period. 'These vessels have regular' stations on the Pacific coast. They abandon these stations during the summer and go to the Siberian Sea. After the season is ended, they return to their stations. One ressel, I believe, is kept on the Pacific coast of the United States during the summer and the remainder of the fleet is sent to the Siberian Sen.

Dr. Hornadir. How many "short "2-year-olds" were killed last vear?

Mr. Lembier. I do not understand your term. No seals under ? years old, to my knowledge, were killed.

Dr. IIORNADir. What would be the age of the smallest yearlings taken?

Mr. Lembker. Two-year-olds rarely, if any. I may state here, Dr. Homaday, that a great difference of opinoin exists between Mr. Elliott and the remaining people who understand this situation. There is a great gulf between their opinions, and it can nerer be reconciled on the question of the weights of skins of "2-year-olds.

Prof. Elliott. I will present my information in a micment.

Dr. HorNADAY. The minimum weight is what?

Mr. Lembrer. Five pounds. During food drives made by the natives, when the seals killed are limited to $6 ?$ pounds, in order to exclude all these 3 -year-olds branded during the summer, you under- 
stand the natives do kill down a little more closely than our regulations allow, for the reason that they need the meat, and since they have to exclude, all these fine, fat seals orer $6 \frac{1}{2}$ pounds they go for the little fellows a little more closely.

The Chairmax. How many seals were killed last year for food by the natives?

Mr. Lembier. The limit was 2,500. Speaking offhand, I think about 2,300 were killed.

Q. Were any females killed?-A. No, sir; not to my knowledge, and, as I stated, I carefully interrogated these two gentlemen who had charge of this killing, and they stated that to their knowledge no female was killed.

Q. What class of males were killed by the natives for food? -1 . Ender 6.1 pounds, which we adopt to exclude all the 3 -year-olds. There may be a few small yearlings in that, but we believe that is the limit of yearlings that were killed for food. There may have been some very small yearlings in that; I don't know.

Senator Herbitix. I would like to ask this witness while on the stand this question: In what market were the skins sold by the Government and to whom?

Mrr. Lambint. They were sold in London: the factor that superintended the sale was Ianingsin of ('o.. the same concern that acted in that capacity for the lessee. and they were sold at auction by that company in London.

(2. Mere they sold in lange batches? - 1 . They were div ided into lots of about 83 or 90 and sold in those lots.

The Crmamman. Did one concern buy all the skins?

Mr. Limerier. I have no idea as to that, but I fancy that bidders were numerous.

Senator Inerorn. Were the purchasers as numerous as the bidders?

Mir. Lenbirer. I have no idea as to that, Senator.

The Cimatrman. Naturally not; they wouldn't do that.

Senator Herbuns. I wanted to get at the combination.

Mr. MCLEAX. Ner the skins are remored, can rou distinguish between a male and female 2-year-old?

Mr. Lembier. Yes, sir: at once. Oh, I beg parion-2-year-olds?

Q. Alter the skin is remored from the animal:-A. If you would fork at the carcass of a "2-year old you could not distinguish it readily, but the man skinning the seal recognizes it the monemt he takes it into his hand to skin it. (I) course he examines the organs and matter's of that kind.

Q. But the aninal is then dead?-A. The animal is then dead.

Q. What I asked you was this -after the skin is removed from the animal, by the inspection of the skin itself could you distinguisin between a mate or a female ?-year old.-A. You could by looking at the teats of the animal.

Q. And are they dereloped on a 2-year-old female!- 1 . I don't know that they are. Fou could find them there possibly. I don't know whetler they are developed or not; I never eximined a skin to find out.

The Chammax. How positive can you be, then, Mr. Lembley, that no females are killed? 
Mr. LEMBreY. The reatson upon which I base that positive statement that no lemales are killed is this: Stringent order's are given (1) all the skimners to report at once any female knocked down in the drives. They are ordered to report it to the agent in charge of the killing and in charge of the men.

Mr. MCLEan. Is there a penalty then inflieted upon the killer for killing the female and when he reports it?

Mr. LEMBKEY. No; because the killing gang consists of six persons, we will say, and it is impossible to tell which one of those six knocked down the seal; but if a female should be knocked down by accident an admonition is given to the clubbers.

Q. So that it is quite possible?- 1 . They are jacked up.

Q. It is quite possible if a female was killed through inadvertence that the native might not report it?-A. No; because the man who reports the presence of the female would not in the least be culpable, becanse he is a skinner, having nothing to do with the killing.

Q. He is probably a relative?-A. I should not say that. There is no great penalty attached to the killing of a female, such as to lead the men to suppress the fact of its presence.

Q. You said a few moments ago that of course you could not be present at every killing. When you are not there, who is in charge of the selection of the seals for the killing gang?-A. There is an assistant agent in charge on every island. As a matter of fact, there are two agents on every island, and one of these is always in charge.

Q. And is he present at the time of the killing?-A. He is actively present; always right on the line among the killers, and so forth anil so on.

Q. How often did you drive there this season, Mr. Lembkey?-A. There were thirty-odd drives made on St. Paul and about 15, I should take it, on St. George. I have these statistics. Of course I did not hear of this hearing until last night and could not get together all the information I have.

Q. How many a week; how many drives a week?-1. Well, on St. Paul there are three hauling-out grounds, and they are driven once a week, you might say.

Q. Do you find through the marking of these various bulls that the same bulls are repeatedly driven or driven several times?-A. Fell, that is a fact that is beyond dispute, really. The same seal is driven several times, there is no douht of that; but we have percentages of hauling in the case of 2-year-olds and 3-year-olds. Te do know that not all of the 3-rear-olds that are marked for breeding come back. Only a certain percentage of them return, whereas, in the (ase of the -year-olds, more return than were marked, so that the rejections of the 2-rear-old chass are greater than the number actually in existence, whereas in the 3-year-old class the rejections are smaller than the number actually in existence.

Senator Herbur. I would like to ask you there if it is true that some seals take to the water and some on the islands never take to the water at all?

Mr. Lembier. There is a period from November until May during which there are no seals present at all.

Q. You have to depend upon the number marked for estimates as to the number that return from the water to the land?-A. Our estimates are based upon the herd when it is present at its greatest. 
nombers eluring the summer. Any estimate we unke is made while the seals are on land. I do not iust exactly gather what rou mean.

Q. Vihen they, take to the water, do they return again to the land?-A. Well. ther leave, pertaps, the midille of vovember, and the first bull does not return until the following "fay. Then the females come along about the middle of June.

Mir. Miclea.s. Mr. Lembkey, in rour opinion, does this frequent driving of the bulls which are rejected have any effect upon their health or virility?

Mr. Lembker. Not in the least. The age of puberty occurs between two and three vears. As a matter of fact, it is almost a subject of microscopic examination to tell whether such a thing occurs, but it would be demonstrated in the breeding herd itselfthat is to say, if cows were found fertilized, you would know that the bulls had properly performed their functions. If, on the other hand, you would find on the breeding grounds a number of cows without pups, then the question would at once present itself whether the bulls were fertile or not. As a matter of fact, we have never found a barren cow, except in several instances where a post-mortem examination disclosed that she had some defect in her organs which. precluded her from becoming pregnant.

Q. I want to read just a short excerpt from your report concerning the Alaska seal fisheries, as follows:

The rookeries of this island were driven twice a week during the past season, with the exception of Zapadni. It is a question if this is not ton often, especially with the fast driving which the natives are likely to make in rainy weather or when the seals from any cause are lively. On our last drive, which was made in a rainstorm, several of the seals were observed with abraded flippers and testes. This condition was observed by both Mr. Chechester and myself, and he ascribed it at the time to frequent driving. I mention it here to suggest inquiry and the remedy. I will add that the condition named was not noticed until our very last sealing.

That was in your report, signed by Maj. Clark, and is dated August s, 1904. Have you changed your views since the time of making that report?-A. I did not make that report, as the gentleman has just pointed out. That report was made by Maj. Clark. The matter that he complains of is abraded flippers and testes. He doesn't mean testes; he means the scrotum. I do not believe an abrasion of the scrotum will affect the virility of any animal.

Q. Just one other point, in respect to the feeding of the seals; the feeding of these bulls. Do you consider that to be wise?-A. I do not, sir; I consider it a disadvantage. Nature provides an eliminative process for the seal. The seal before it has learned to feed and before it has learned to swim beyond the borders of its rookeries and before it has learned to seek food for itself, is driven by the climate of the land and forced to make its first winter migration in the waters of the northern ocean. That seal has to withstand such hardships as eliminate all but the strongest and the most rigorous. Those that come back to the islands the following spring have no physical defect.

The Cmammax. We only have a few more minutes. Mr. Elliott has been in the city for two or three weeks and is recognized as the eariy authority on seal life, and we would like to hear from him as to the purpose of this closed-season proposition, as to whether or not it is the wise or necessary thing to do.

$95100-$ No. $1-11-2$ 


\section{STATEMENT OF PROF. HENRY W. ELIIOTT.}

Mr. Eudort. Gentlemen, and members of the committee, I want to say that so much has been well covered here by the chairman and by Di. Hornaday, and by the other gentlemen, that I shall not say a good deal that I intended to say. I shall confine mysell to the question of the preservation of seal life, which Mr. Lembkey has just declared to the committee that he is saving.

Let me picture to you the arrival of a seal and the way it is "saved" on the islands, and then this committer will be able to understand that in spite of "saving" and "protecting" this life the operation of this work on the islands is absolutely null and roid. The seals arrive in June: ther are welcomed by Mr. Lembkey and the natives, as he says. They are the "fine fellows," the "early swimmers" to the islands. He welcomes them. He has his natives down there at the surf margin, and they drive them up to the village where they bring on a forked stick and pin them down one by one by the necks and heads. Then they shear off a little tuft or patch of hair from the neck or the skull caps. Very well. Ther pass. They come back from the drives once or twice, perhaps three times cluring the season. They are "spared," are they? Let us see.

Wiliere have they gone after Mr. Lembkey "spared" them and sheared them as immume? They have gone to the hauling-out grounds and then they have gone out to sea to retun again. They have run out through a gantlet of Japanese luunters, 3.j vessels [Lembley tells us], which equals"2,500 men, watehing for them. Then as they go out that gantlet-out to the "old mill pond" where they feed, some 80 or 100 miles away, there they meet our pelagic (anadian hunter friends. They escape, perhaps, and then in the same way run back to the islands. After two or three weeks passed there then they are off again to feed and return; thus, they run this gantlet again and again, do these "spared" seals, still with this mark on their hearls, and we assume they are not killed up to date.

The season goes on. Mr. Lembkey and his men have "spared" these seals all right; perhaps the Canadians and the Japanese hunters have spared them. Granted they have. September comes. They have come back to the islands. They have shed their hair by the end of September and they haul out in October with not a mark upon them and not a sign of the mark that Mr. Lembkey has put upon them last June and July.

Then what happens, gentlemen? "Those are nice seals," says Mr. Lembley. "We need some food for the natives. Kill them." They are rounded up and they are killed wherever they are found.

Give me that Senate document No. 98 and I will read the official record of their killing, after they are "branded" or "spared," in July. I want Mr. Lembkey to face this.

Mr. LEMBKEY. I will admit the statement in the document.

Prof. Elliotr. That report is true. It is by Mr. Judge, who is here, introduced to me as your associate and your equal and your brother official.

Mr. LembKey. And superior, perhaps. 


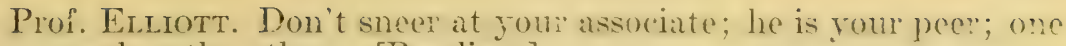
is as good as the other. [Reading:]

Report of Agent James Judge - -

Senator Herburx. State the document and the page from which you read.

Prof. Elziotr. Senate Document iVo. 9s. Ioifty-nintl ('onwess, first session, pare 86. Here is the official report of IIr. IV. I. Lembkey, in which the preservation and protection and conservation of this seal life, which he so graphically described to you a moment ago, is hlown clear out of water by its own force of official denial.

REPORT OF AGENT JAMES JUDGE.

St. Georat Island, June 5, 1905.

Dean Sir: I have the homor to submit the following report of afiairs on st. (iempe Island, covering the interval from August 14, 1904, to date:

SEALS,

On (octoler 7 Little East Ponkery we rarefully gone over for the purpose of comuting dead pups, but none were found.

At that season foxes in wreater or less numbers are always present on the rookeries and quickly eat the pups or older animais that may hapmen to die. Pup skulls were frequently found during september in the rear of the ronkeries, where they hat undoubtedly been left by the foxes, the bodies having been devoured.

Further comting of dead pups was therefore not attempted, as it seemed a disturbance of the seals to 110 good purpose.

The first food drive was made Oetober 19; killed, 59; dismissed, f large; 197 small and 6 brands. Two of the latter were from St. Paul. Thile all brands were very faint, those made with shears were less discernible than those made with hot irons. Just the slightest trare of a brand on one of the deal informed us that the wrong animal had been knorked down. The skin weighed 8 pounds. That other 3 -yearolds hranded in the spring. on which the fur had grown ont so that the brand had become obliterated, were alsis killed is more than probuble, as 69 per cent of the dead skins weighed 7 pounds and over, the heaviest weighing 9 pounds.

Mr. Lembier. May I interupt the grentleman just a second to ask whether the report does not state that Mr. Judge at once took measures to prevent the killingr of any more of these branded seals by limiting the weights of skins to $6 \frac{1}{2}$ pounds, a practice which has been followed ever since?

Prof. Elliott. Six and a half pounds also carries big skins. You sared no seals last spring that weighed 8 pounds. They never haul out there now, and they are not there, and you know it.

The average of this class of animals killed from the 20th to the 30 th of last July was $4: 3$ per cent. while that on St. Paul during the entire sealing season was only 34 per cent. The paucity of branded seals in the drive as compared with drives made in July lead to the same conclusion. (See statisties regular killing for quuta 1904.)

At all sulsequent killings I endeavored to restrict the slaughter to 2-year-olds. with considerable success.

October 24 a bod drive was made irom East rookery and 30 killed. Among this lot 2 skins were found that had heen hranded, hut the lirands were too faint for detertion while the animal was alive. These skins weighed $6 \frac{1}{1}$ pounds each.

That other hranded 2-year-olds on which the brands had entirely disappeared were killed during the autumm is more than probahle, but for this there was no apparent remedy without a radical revision of the rules governing sizes.

'fo remove all possibility of killing loranded seals in the fall on which the lorands have become indistinct it will be necessary to prohibit the slaumher of any animal the skin of which weighs over if pounds. This will confine the killing to animals with skins weighing not less than $\frac{1}{2}$ nor more than fi pounds. Such a rule is laadly practicable. 
And so ther killed these fine seals, fo! per cent above the average. Why dis they kill them? For food? Do the natires want these big seals for food? No.

In my opinion, however, a relaxation of the minimum rule as regards weights of skins should be permitted at focd killings on St. George.

That is his opinion: that is what he alludes to: but the returns from the Landon sales show that killing the big seals is a common sequence.

Senator Clark of Wyoming. Prof. Elliott, what percentage of the entire killing is included in the kill for food?

Prof. Elziotr. That is a difficult thing to get, because they will carry these food skins over into the quota for the next year, and they are sold in London, and I can not prove it.

Q. I am not asking you what you can prove: but you are very familiar with aflairs w) there. Haven't you some sort of an idea of how many of thase animals are killed there every year?-A. They killed 614 , for instance-

Q. Six hundred and fourteen out of how many thousand? They killed 12,000 last year.

The Champix. 'Two thousand three hundred, Mr. Lembkey stated, were killed for food. What becomes of the skins of the 2,300 killed for food, Mr. Lembkey?

Mr. Lemвкеy. They were delivered to the lessee, just the same as those skins which the lessee took himself.

Q. But since the Government took charge?-A. They are shipped to London. Skins were not taken that were not eligible.

Q. But the 2,300 skins that the natives kill for food are turned over to your London factor for sale?-A. Yes, sir.

Prof. Ermioxt. Mr. Lembkey says there is a great gulf between the official knowledge to-day on the seal islands and the oflicial knowledge which existed when I was a member of the Government staif up there. There is a great gulf. In 1872, 1873, and 1874, as an officer of the Government, I cooperated with four official assistants and seven agents of the lessees in preparing a table of weights and ages for skins of seals. That tabulation and agreement, made official and officially published by the Government in this official monograph and republished by the Department of Fisheries as Special Bulletin No. 176, 1882, page 81, has been the standard, unquestioned and undoubted by any living man, until Mr. Lembkey put a table forward two years ago to cover these short weights which he was taking and sending over to London as "2-year-old males." This official publication, passing through the hands of dozens of men oflicially before irr. Lembkey came there, and agreed to and officially submitted and published by the Government 30 years ago, is changed by him to-day. Why? Have the seals changed in their annual order of growing and weights? No. The seal that is born on the islands to-day is born exactly as it was 30 years ago. After he is reared, he goes to sea and comes back, lives and dies, exactly as I studied it 30 years ago and described it.

Where is the gulf? The gulf is in the recent assertion of these gentlemen; not in the official fact, which was agreed to for years and years before Mr. Lembkey came there, and never was disputed, even by my bitterest enemies, until two years ago, when this question was 
furtively raised and a table put out to shield this work in this Senate document No. 98.

I brought this question of weights and sizes up before Mr. Hitcheock in 1904, who had charge of the seal business. Mr. Lembker was in his office. He remember's well the sessions I had with Mr. Hitcheock over this business - over the preparation of regulations which would forbid them from killing down too close. Mr. ITitcheock called his advisers together-Dr. Jordan and the rest of the "scientific" officials. They said: "No; there isn't any need to make this reserve which Mr. Lembkey is so proud of talking about to-dlay. Don't need it. Elliott is a crank and a tiresome fellow." But, Mir. Hitchcock said, after weighing the eridence and facing the Committee on Wars and Means (for I had to bring them up there to get a settlement), that the Department of Commerce and Labor would put this check on their work; that they would make this reservation, in accordance with my recommendations, as to the need of it. What followed? The regulations were prepared and issued May 1, 1904, so that "nothing under 2 year's of age" should be taken, and under the skin weight of $5 \frac{1}{2}$ pounds-as the minimum weight to be taken. That just saved them, because a well-grown "yearling's" skin will weigh $4 \frac{1}{2}$ pounds, and a "short" 2 -year-old will weigh 5 poundsa "runtr," a "short" 2-year-old will weigh 5 pounds, a good 2-yearold skin weighs 6 , with its half pound of blubber attached.

Mr. Hitchcock put a minimum of $5 \frac{1}{2}$ poumds. What followed? They came to him, the lessees, and urged him to reduce it to a 5-pound minimum. He refused. Two years later it was changed by order of the Secretary of Commerce and Labor to a minimum of 5 pounds, and every "short" 2-year-old and every "long" yearling seal that comes out on those islands is raked in and killed. After this "reservation" in June has been made this check on the destruction of that life is thus nullified at the expense of our people in the name of "official science."

I am tired of it. There is a gulf between fact and fiction as to this business, and there is imperative need that these herds on those islands shall be turned back to the solitude and peace which God Almighty created there in the beginning, which alone can restore that life to what it was. The can not do it. This ranity and frilling about in the name of "science" by these men, this "selection" and this impotent "improvement" on the laws of the Creator is absolutely grotesque and futile. That life is ebbing out day by day as we sit here. Nothing has been clone since 1890 to stop it. "It is a long story. I have documents, figures, and facts which cover the whole thing from start to finish, which show that nothing since 1890 , when I then came down here and started this very same bill now before you, has been done. I wanted the lessees taken from the islands then and some provision made for their property, and I wanted these seals sent back to their Creator for a rest and a chance to regain their strength.

I knew very well we could not do anything unless we stopped killing on the islands. The British would not submerge their private interests-" Not until you put your butchers down," they said. They were right in 1890 ; they are right to-day. They waited all last summer to see what we were going to do. Did we do anything? Oh, no: just butchered seals as usual. I will tell rou, gentlemen, what we did. These "official science" advisers of "Secretary Nagel, headed by Dr. Darid Starr Jordan, the "prince of peace," who don't believe 
any of it - this "prince of peace" asks our State Department to do what? To invite Japan, Russiat, ('anada, and ourselves to attend a joint international conference, wherein we will "protect" the seals, the blue foxes, and the walrus, and the sealions, and the whales, and all other things mostly marine life, or in the water. That is all that has been done since this bill was passed. Now, we know what is being done; but, of course, it was adrerted to this morning, and I am glad it was. Things are coming our way. If they were not, I would open a box to-day. But I will say nothing, because I think the end is close at hand, and just as we want it, gentlemen.

But, gentlemen, let fiction pass for a moment. The hides of the seals are taken as mercilessly on the Pribilof Islands to-day, and as greedily, as those butchers have ever taken them in the water. There is not the slightest difference between the spirit which has animated the one or the other, and the influence here in Washington has been so strong that nothing could be done to dislodge them on the islands; until they were dislodged on the islands, you could not do anything at Ottawa. But let it be said to the infinite credit of the British ambassador and the infinite credit of Sir Wilfred Laurier, that there has not been an hour since 1905, when Joln Hay, and Sir Mortimer Durand and certain United States senators united in an agreement that we could not have closed in forty-eight hours-this whole business, and have sent this question of saving the seals back to the Creator, who alone can restore it.

Don't talk about trouble with Japan or with Russia. The trouble is with ourselves. I have nothing more to say; it is not necessary. I have documents, figures, books, and reports here, and if anybody wants to question my statements, I am ready to meet them.

The (hamman (Senator Drlungham). Are there others to be heard?

Dr. Hornadiy. That is all we have to offer, Mr. ('hairman.

The Chairman. The committee will then rise.

(Thereupon, at 12 o'clock and 10 minutes p. m., the committee adjourned.).

In re Fur Seal Herd of Alaska.

\section{Hon. John H. Rothermel,}

Chairman Committee on Expenditures in the

Department of Commerce and Labor,

House of Representatives, Tashington, $D$. C.

SIR: It is my imperative duty as a good citizen, and possessed of abundant knowledge, authentic and indisputable and of oflicial and current record, to submit the following charges and proof of them for the consideration of your honorable committee.

Cmarge I.-I charge that the conduct of the officialism of the Department of Commerce and Laibor, having the specific control of all details of administration of the public business on the seal islands of Alaska since January 1, 1905, has been guilty of violating the law and regulations which it is and was the sworn duty of that officialism aforesaid to properly and strictly obey.

Cinarge II.-I charge that this malfeasance of that officialism, above cited, has caused an immense loss of public property on the seal 


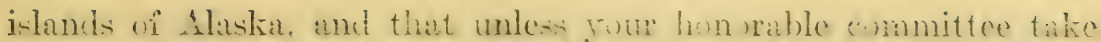
prompt action to check and aholish it this same oredialism will in a short periok of continuance of its methuds be able to and will succeed in completely destroring the commercial ralue furever of the fur-seal herd of Alaska.

The rharges. rentlenem, ane serious; they are made with a full sence of their gravity; they will be sulnmiterl now in detail to you as fact suceeeds fact of oflicial reeord in the premises: no assertion. no opini on of mine or anyone else will be eren hinted at, mule less mentioned by me, in tie following exposé of tlis improper and illegal work of those agents of our Govermment in charge of the care and conservation of the public interests on the seal islands of Aliakia.

As to Charye I.-On the $3 \mathrm{~d}$ of May, 1900, I entered into an engagement with the late John Hay to furmish him with the expert fur-seal knowledge, which he desired to possess, with which to enable him to set aside the erroneous findings of the Jordan-Thompson Commission, as written into an official joint agreement Norember 16, 1897, at the State Department. These findings prevented any revision of the rules and regulations of the Bering Sea tribunal, as ordered August 16, 1893, and enforced April 24, 1894. These rules and regulations. actually facilitated and still facilitate the destruction of our fur-seal herd instead of protecting and conserving it.

On the 26th of November, 1903, Mr. Hay and I learned that no change in these Bering Sea rules would be agreed to by Canada unless we suspended the work of our lessees on the seal islands of Alaska.

On the 8th of January, 1904, I addressed a detailed letter to the Secretary of Commerce and Labor, setting forth in detail those reasons why the work of the lessees should be discontinued on the seal islands and why they were injurious, and why, if not checked up, would compass the complete extinction of the commercial value of the fur-seal herd.

On the 12th of January, 1904, Senator Dillingham, as chairman of the subcommittee of the Senate charged with Alaskan affairs (by Senate Resolution 16, of March 19, 1903), introduced Senate bill 3.555 and a report of that committee (S. Rept. No. 282, 58th Cong., 2d sess). This bill and report was for the complete suspension of this work of the lessees on the seal islands of Alasha and in exact accord with the views of Secretary Hay and myself on that issue.

Not being able to get any response from the Secretary of Commerce and Labor to my request that this work of the Seal Island lessces be suspended, with the conperation of Secretary IIay, I carried this issue to the Ways and Means ('ommittee of the Mouse of Representatives early in Slarch, 1904; on Narch 9-10. 1904, the committee heard me and ilr. F. Hitcheock, chief clerk of the Department of Commere and Labor. Mr. Hitcheock said that while all of the officialism in charge of the seal herd was opposed to any interferenee which the work of the lessees. Fet he was of opinion that some check such as I desired ought t') be male. He therefore said to the committee that he was delegated by the Secretary to pledge the department's action in that direction. This pledge was to put an immediate partial rheck on the killing by the lessees and a complete suspension of that work whenever Great Britain would suspend her work at sea.

The Secretary of ('ommerce and Labor. on fiay 1, 1904, ordered this check upon the work of the lorees, as pledged to the Ways and 


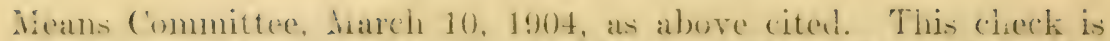
known as the "IIteheock rules," of May 1, 190t. (Nee S. Doc. No. 114, 58th ( long., 3d sess., p. 3.)

During this hearing, on Warch 20, 1904, before the Mays and Means (ommittee, as above citcel, Air. Iitcheock submitted to the (ommittee as his idca a table of the weights of those green sealskins, as to their ages when taken by the lessees. (This is published in the hearing, and made an appendix to his remarks.) lir. Ilitcheock mate a great blunder in compiling it; he frankly admitted the same to me when I took the printed copy of this hearing to him, March 31 , 196) $\frac{1}{2}$. He promised to correct this blunder and make the Hitcheock rules in accordance. He did so (see p. 9, S. Doc. No. 114), and fixed a minimum of $5 \frac{1}{2}$ pounds for the smallest skins, and further ordered that no seals "under 2 years of age" should be taken. Thus, clearly and positively, after this order of May 1, 1904, all killing or any killing of yearling seals by the lessees was in violation of law and is to-day.

The following letter explains fully this blunder of Mr. Hitchcock and why the Hitcheock rules made $5 \frac{1}{2}$ pounds the minimum, instead of 5 pounds, as the erroneous table ordered.

Hon. Sereno E. Payne,

Washingtox, D. C., March 31, 1904.

Chaiman Committee Ways and Means.

MY Dear Sir: On page jof of the hearing orer the Alaskan fur seal herd, belme the IVars aril Heans ('mmnillee, March 9-10, 1904, is a table of dlakkail seal skin weights submitted in evidence by the representative of the Deprartment of commerce and Labor.

I respectully desire (o) call your attention to a grave and indanental emor in the

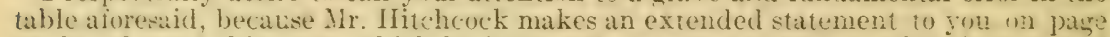
56 , based upon this crror, which he innocently assumes to be an authentic record of the London sale covered by this table.

In this table you will observe that the class of "middlings and smalls" is omitter from the order of weight averages, and in its place the class of "smalls" has been erroneously inserted.

This erroneotis insertion moves all of the lower classes, including the "smalls," up, wrongfully one year in age. Thus the 2-year-old seals or "large pups" ("6-pound" skins), are made to take the place of the 3 -year-olds or "smalls" ("7 to 8 pounds" skins), and so on to the end of the list.

In this way Mr. Hitcheock has been inposed upon, and a ficticious showing of only 2,272 yearling skins is made, when, in truth, 13,000 of this catch classified in that table are yearlings or "5-pound" skins.

I have called Mr. Hitcheock's attention to this error, and he now understands it. He will not, therefore, make the blunder of allowing the lessees to take "5-pound" skins, or "yearlings" next summer, and thus violate his pledge to your comnittee. He will fix the minimum skin weight at " 6 pounds, "and thus insure the killing of nothing under 2-year-olds.

I am, very respectfully, yours, etc.,

Henry W. Ellio'tt.

In this distinct and explicit order of May 1, 1904, published by Secretary of Commerce and Labor, any killing of yearling seals on the seal islands by the lessees was made illegal, if so done; was it done? It was-it was immediately resumed in 1904. just as it had been done on those islands since 1896 . Olsserve the following proof of it which has thus far never been met or denied over the signature of any Secretary of commerce and Labor. As you read this evidence, gentlemen, please bear in mind that this check ordered on that hilling. by the lessees, known as the "Hitcheock rules" of May 1, 1304, was literally forced on the Secretary of Commerce and Labor by myself and the senatorial committee (Gor. Dillingham, chairman). We did this between the sth of Jamunry, 1901, and 
March 20, 1904. I wish rou to bear this fact in mind, also, that this officialism which riolated that order and pledge to Congress in 1904 is the same subordinate olticialism which is to-day still in charge of that life, and it was engaged in this same violation of the "Hitchcock rules" up to date of August 1, 1910, when the sealing slaughter work ended for that season.

The following open, clear exposé of it which I made in the kindliest and most charitable manner was silently and brazenly ignorerl by Mr. Metcalf and these same subordinates who to-day have led Mr. Nagel into the mire of that illegal slaughter by his orders last summer.

[Senate Document No. 149, Fifty-eighth Congress, third session.]

\section{Washington, D. C., February 6, 1905.}

MY IEAR SiR: I have a copy of the letter from the Secretary of commerce and Labor transmitting to the Cnited States Senate a transcript of the regulations and instructions which were made and ordered by the department for the conduct of affairs on the real islands of Alaka, dated May 1, 1904, and aloo the rejort of the agent in charge of the seal islands, dated August 12, 1901 (S. Doc. No. 114, 58th ('ong.. 3d sess.)

These regulations and instructions are an immense improvement over the Treasury recrulations of 1903 , which they supplant; they are admirable, in so far as they safeguard the public interests, as they should be in almo-t every respect. They alen distinctly instruct the agents of the department as to specific lines of duty, and distinctly assert the complete control of the business of taking fur seals, as it is rested in the Government, even though it is leased.

The recervation made by these regulations of 1,000 2-vear-old male seals and 1,000 3 -yent-old during the season oi 1!n) 1 . by which these young bulls shall be permitted to grow up and go orer to the breeding grounds in 1907 and 1908 , and so prevent at that time the complete extermination of the virile male life on the rookeries which otherwise would take place, seems to have been faithfully carried out by the aqents of the department.

But in this connection that order of reservation must be extended to 4 -year-old males next season (1905) or the 3-year-sids saved as such in 1904 will be taken by the lessees. Unless this extension to the 4 -year-old class is mate for 1905 the reservation of the 3-year-olds in 1904 will be mullified by the lessees in 1905. Beyond this point I can see no flaw in the text of these "Hitcheock rules and regulations" aforesaid.

With regard to the report of the agent in charge of the seal islands, several significant disclosures are made in it as to the condition of the herd up) to August 1,1904 .

First. Only 10,232 fur seaIs were secured in the season of $1904-i$. e., from June 1 to August 1 -nearly all yearlings and 2-year-olds, nine-tenths of this catch being $4 \frac{1}{2}$ to $5 \frac{1}{2}$ polind skins.

Second. So close were these seals driven and taken in that time that nothing escaped the club on the killing grounds exrept the "runty" yearlings ( $3 \frac{1}{2}$ to 4 pound skins), and the old and vagrant bulls which were scraped up by the drivers in their effort to get every killable male seal-i. e., every $t^{\frac{1}{2}}$ to 7 pound skin-that was in sight at any time during the season.

The agent says that in all this driving there were " 641 large rejections"-i. e., bulls of any age from 6 years to 18 -but this count of "641 large rejections" does not mean that 641 individual bulls were so rejected, not at all. Some of these individual bulls have been counted six, eight, or ten times into this total of 641 , as they came up in the semiwekly and weekly drives to be released and then redriven over and over again until the end of the seison, therefore the " $6 \pm 1$ large rejections" mean no more than 200 or 250 vagrant, worthless bulls, which are useless as breeders and valueless for skins.

The " 4,794 small rejections" mean sune 1,000 to 1,500 undergrown yearlings or "runte," which the "Hitchcock minimum limit" of a 5 - - pound skin exchuded. These "runts" could not be "loaded" with blubber so as to weigh into 5. pounds, and pass the Government agent's limit; but all of the a verage yearlings or $4 \frac{1}{2}-p o u n d$ skins were easily luaded with a pound of blubber in skinning, and so passed up to the minimum limit of $5 \frac{1}{2}$ pounds.

Third. The agent tells us that "uo yearlings were included in the catch and but few were seen in the drives." Then he unwittingly denies this statement by telling us that he "killed one yearling during the summer to determine the weight of that cliss of skins. The entire animal, a female, weighed 33 pounds and its pelt weighed $3 \frac{1}{3}$ pounds." 


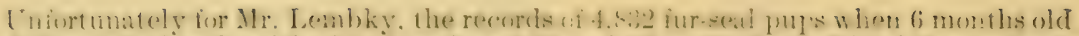
and then killed and weighed in bunches w 25 and 50 on st. Panls Istand Vovemher 5

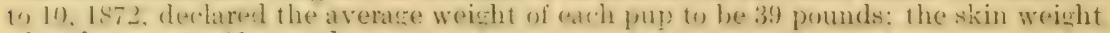
of each pup was 33 pounds.

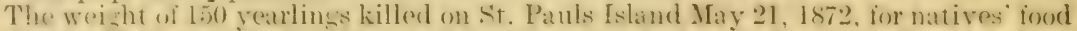

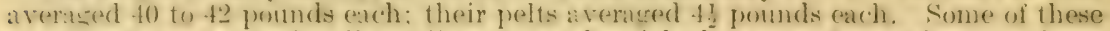
yearlings were exreptionally well grown and werighed uy to a j-pound pelt: others, is fow only, were "runts," and dici not weish up above a $3 \frac{1}{2}-$ poumd or pup)-skin weight.

Fomrth. So, instead of seping no yearlings in the drives, this asent has taken them just the same, and has "alled them "2-year-olds," and the reoord of the London sale if all of these skins a fow months later declares his himber. The skin which he calls a yearling and which "weiphert $3 \frac{1}{3}$ pounds" was a "runt:" it is classified as an "Ex. ex. sinall pup" in the London sale; a t-pound skin is an "Ex. sm. pup;" a $4 \frac{1}{2}-p o u n d$ skin is a "suall pup" or average yearling: a 5-pomel skin $10.5 \frac{1}{2}$-pound skin is a " Midnling pup," which is a "long" yearling or a "short" 2-year-old; and a "Large pup" is a 6 -pound skin to a $6 \frac{1}{2}$-pound skin, or an average well-grown 2 -year-old male soal pelt with the usual one-half pound of blubber adherent as cut from the carcass in skinning.

Fith. This admission of the Government agent that he has taken every young seal that hanled out on the seal islands of Alaska during this season of 1904, save a few "runts" which the Hitchcock restrictions could not be stretched down low enough to admit of his taking, points out the exact and positive truth of what I assured you last winter with regard to the condition of this herd on the Pribilof Islands.

I to!d you theil that the records of the London sales of the Pribilof catches from 1900 to 1903 , inclusive, declared that the lessees were actually draining the very dregs of the youmg male life, and permitting nothing to escape for service on the breeding grounds.

Now we have the explicit admission of the agent in charge of the islands, who, at the close of the seasun's work of 1904 , reports this fact to his chief. He does not mean to tell all he knows, but he "an not help it. The records of the London sales, December 16, 1904, show exactly the size and weight of every one of 5,000 skins which the lessees took during June and July, 1904, and up to the end of the season. Then he tells us that he has not taken any yearlings this year, and "few were seen in the clrives" (1904), and does not know what has become of them.

But the agent of the lessees who sold these skins, taken under Mr. Lembkey's eyes. on Sit. Paul Island last summer, tells us on December 16, 1904, that nearly nine-tenths of the catch are rearling skins. He does so, ber'ause the bicliers at this sale can not be deceived by the appearance of these skins, which are always exposed to their inspection four weeks annually prior to this public sale.

The following is an epitomized record of that regular annual London sale above cited: Twenty thousand Pribilnf skins were offered and sold; 5,060 of this total being the catrh of 1904 , and 15,000 being the balance of the catch of 1903 , which were carried over to this sale, this leaves 8,000 of the 190$) 1$ ('atch to be carried in turn over to the sale of December 16, 1905.

London classification of 5,000 stins, taken on the Pritilof Islunds, June and July, 190.', sold December 16, 1904.

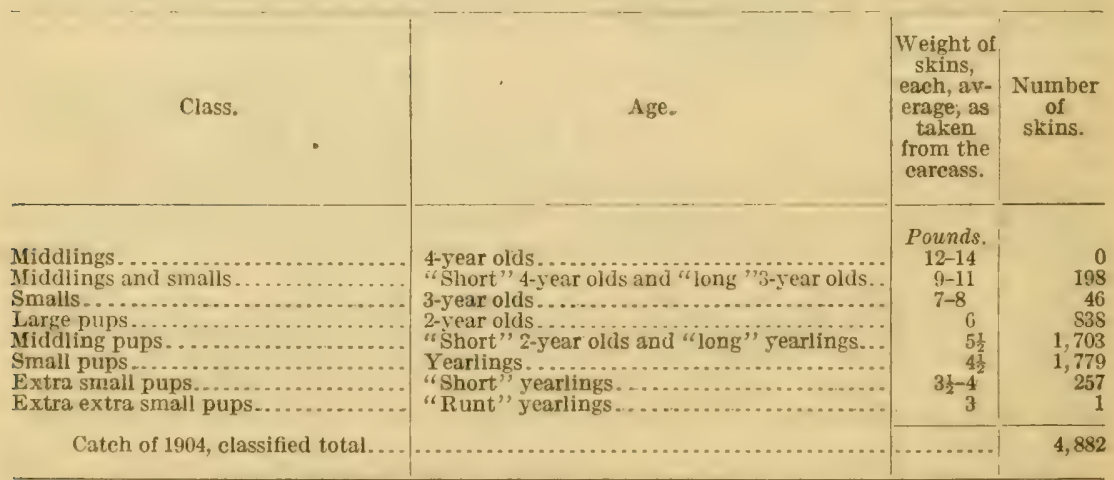

With IIS shins not rated, but offered as "faulty," "cut," etc. 


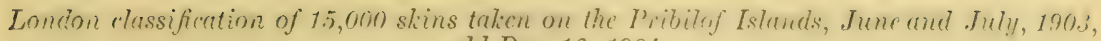
sold Dec. 16, 1904.

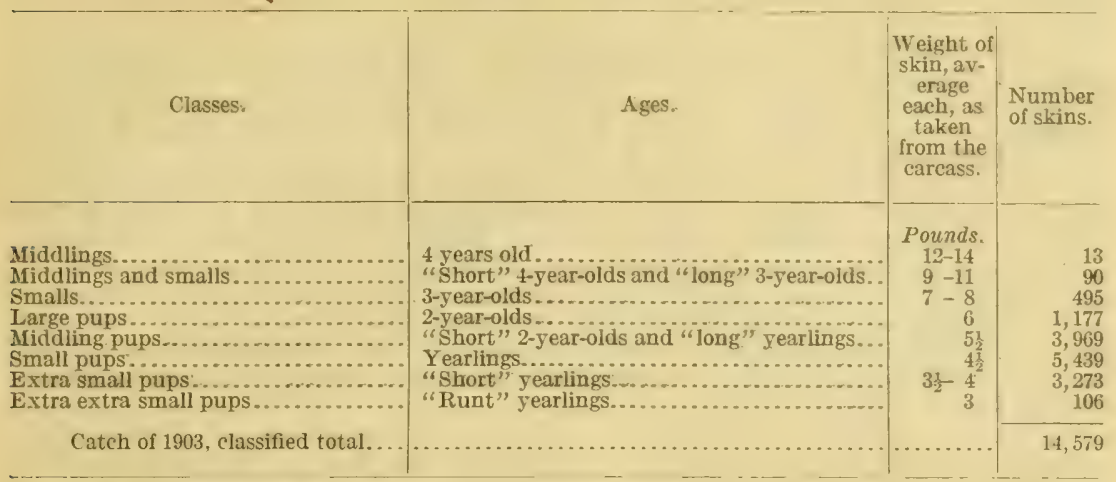

With 421 skins not rated, but offered as "faulty," "cut," etc.

Here is the evidence presented in these records of the London sale above cited, which declares the fact that the lesees have taken at least 12,000 yearlings, which appear as 3 to 5-pound skins in the above itemized classification in a total of 19,461 skins. I say "at least" 12.000 skins of yearlings. I may say that it is within the line of fair statement to claim that this record of the London sale warrants the assertion on my part that the lessees have taken 15,000 yearlings out of this sum total sold on the 16 th of December, 1901, nime-tenths of the balance being "short 2-year-olds" and "long yearlings," or $5 \frac{1}{2}$ to $5 \frac{3}{4}$ pound skins.

In order that you may the better understand the full significance of this rapid disappearance of this young male life on the seal islands of Alaska, due to excessive killing by man, by land and sea butchers, I submit the following table, compiled from the records of the annual London sales, where all of the catch of the Pribilof Islands has been sold since 1870 :

Class.

\begin{tabular}{|c|c|c|}
\hline $\begin{array}{l}\text { Season } \\
\text { of } 1872 .\end{array}$ & $\begin{array}{l}\text { Season } \\
\text { of } 1890 .\end{array}$ & $\begin{array}{l}\text { Season } \\
\text { of } 1904 .\end{array}$ \\
\hline $\begin{array}{l}\text { Skins. } \\
34.000 \\
40,000 \\
26.000 \\
\text { None. } \\
\text { None. } \\
\text { None. } \\
\text { None. } \\
\text { None. }\end{array}$ & $\begin{array}{r}\text { Skins. } \\
159 \\
500 \\
2,939 \\
5, \mathrm{~T} 44 \\
7,694 \\
3,752 \\
71 \\
\text { None. }\end{array}$ & $\begin{array}{r}\text { Skins. } \\
13 \\
288 \\
541 \\
2,015 \\
5,672 \\
7,218 \\
3,530 \\
107\end{array}$ \\
\hline 100,000 & 20,249 & 19,284 \\
\hline
\end{tabular}

Midalings......

Middlings and smalis

Smalls...

Large pups.

Middliner pups.

Small pups.

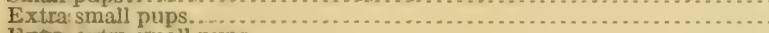

Extra extra small pups.

Total.

These indisputable figures eloquently declare the fact that the very dregs of the young male life on the Pribilot seal islands were drained by the lessees in 1903 and 1904. They declare the fact that there is nothing left alive on the islands up to August 1, 1904, of the male life above the "runty" yearlings, or any male life under the old bulls, except the young 2-year-old and 3-year-old bulls which were spared by the new Hitchcock orders of May 1, 1904.

They also declare the fact that if the new Hitcheock restrictions are extended so as to save in 1905 the 3 -year-olds which were spared in 1904 , that there is nothing left alive on these islands which the lessees can lawfully secure during the season of 1905, except as they stretch these restrictions, as they did last season, and scrape up. a few thousand "long" and average yearlings, as "middling pups" and "small pups," of these small seals; they may possibly secure some 6,000 or 7,000 ; no more, that is certain.

Having compelled the saving of a few thousand young males to live and grow to the physical standard necessary in fur seals for service on the breeding groundshaving done this by the Hitchcock restrictions of 1904-we have prevented that complete extermination of the breeding male life on the rookeries by 1907 which otherwise would have taken place. 
This understoxd and agreed upon, we come now to face another question, exually interesting and equally important, to wit, What effect upon the increase or the diminution of the nucleus of that fur-seal herd will this preservation of those voung male seals have in the future?

To this question I make answer that while this saving of the choice young bulls began in 1904, and annually enforced hereafter, will prevent the complete extermination of this fur-seal life, yet it can not and will not prevent its annual diminution by 1908 down to a number of 25,000 or 30,000 seals of all classes; to-day there are about 128,000 seals of all classes, $\delta, ?$, and $\odot$.

It can not be otherwise; it is so because a fleet of 20 or 22 pelagic hunting schooners, manned by trained hunters of long experience, are hanging upon the flanks of this remnant of our herd to-day. Last season, 190t, these men took 31,000 seals from the sum total of the Pribilof herd and sold them all in London-29,000 on December 16 , 1904 , and 2,382 on January 23,1905 -at an advance of 10 per cent over the high prices of 1903 , making an enormous profit to the owners of these skins of not less than 120 per cent. Therefore, these hunters will not quit as a body until the bottom to their business suddenly falls out, as it will by 1907 and 1908 under the regulations and conditions that now prevail.

Therefore, in answer to this query as to increase or loss of this life, I submit the following statement as to the present condition of the Pribilof fur-seal herd, with reference to the immediate future:

Annual R.itio of Diminution which will Ensue from 1904 to 1915 AND Indefinitely Thereafter Under Existing Conditions.

When the agents of the Government finished their census of the fur-seal herd as it existed on the Pribilof Islands during the season of 1904, up to August 1 they reported that there were about-

"('ows" or female seals, adult (2 years old down to 12 years old)........... 85,000

"Bulls," most of them very old (12 years old down to 18 years old)........ 2, 200

"Pups,", born June and July (20,000 die from starvation in September and

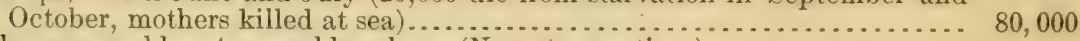

Three-year-old or 4-year-old males. (None to mention.)

Two-year-old males (2,000 of them saved from the club by the Hitchcock

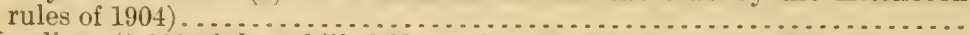

Yearlings (3,000 of them killed November 10, 1904, for natives' food):

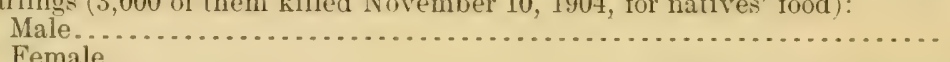

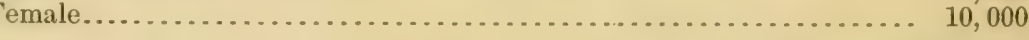

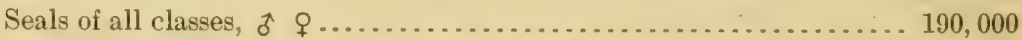

But from this total must be subtracted 31,000 seals taken by the pelagic hunters and 13,000 yearlings and 2-year-olds, $4 \frac{1}{2}$ to 5 pound skins, taken by the lessees during the season of 1904, and 20,000 starved pups, their mothers killed at sea during August, September, and October-62,000 seals. This leaves the sum total of fur seals alive at 128,000 of all classes. But this is not the real significance of that diminution in number; its significance is due to the fact that three-fourths of the pelagic catch of 31,000 seals are adult females, which must be subtracted from the 85,000 cows, so that less than 63,000 cows were left alive by October $15,1904$.

Under existing rules and regulations which now govern the business, unless changed, the pelagic hunters will secure in the season of 1905 some 25,000 skins and the lessees some 8,000 skins. Three-fourths of the pelagic catch will be adult females. That requires a subtraction of some 20,000 seals from the 63,000 cows which come over from 1904, and about 15,000 pups from the 60,000 born during July, and 8,000 yearlings from the 16,000 which come over from the pups of 1904 . This would make the census for 1905 , by October 15 , about as follows:

Cows from 2 years to 11 years old ............................ 45, 000

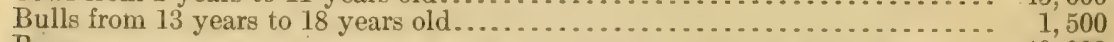

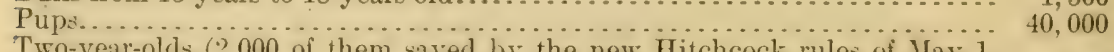

Two-year-olds $(2,000$ of them saved by the new Hitchcock rules of IIay 1 ,

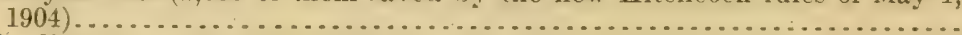
Yearlings:

Males (of these, 2,500 will be killed November 10, 1905, for natives'

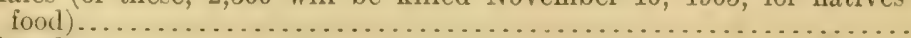

Females........................................................ 15,000

Fur seals of all classes alive in the Pribilof Islands, October 15, 1905. . 111,000 
With no change in existing rules and reculations, the pelagio hunters will socure in the season of 1906 some 15,000 seals; the land catch will not exceed 5 , (0)0 snall male seals, of which 2,000 will be spared. This would make the census for 1906 , by October 15, about as follows:

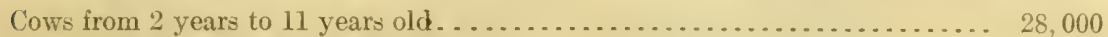

Bulls from 14 years to 18 years old . . . . . . . . . . . . . . . . . . . 500

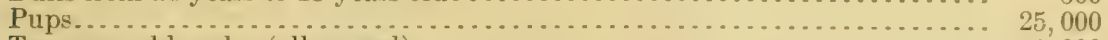

Two-year-old males (all spared) ............................... 1, 000

Yearlings:

Males $(4,000$ killed for natives' food, November 10, 1906)......... 6, 000

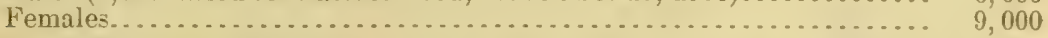

Fur seals of all classes alive on the Pribilof Islands October 15, 1906. _ (69,500

With no change in rules, and this same order of work repeated in 1907 , the pelagic hunter will secure some 12,000 seals and the land catch will not be more than 3,500 to 4,000 yearling males - just enough for the meat needed for natives' food. 'This would make the census for 1907 , by October 15, about as follows:

Cows from 2 years to 11 years old ........................... 18, 000

Bulls from 6 years to 18 years old (new bulls saved in 1904 now come in)... 400

Pups.............................................. 16,000

Two-year-old males (all spared on land by Hitchcock rule) ............. 1,000

Yearlings:

Males (2,500 of them killed Norember 10, 1907, for natives' food) ..... 5, 000

Females........................................ 8,000

Fur seals of all classes alive in the Pribilof Islands, October $15,1907 . .48,400$

With no change in rules and this same order of work repeated in 1908 , the pelagic hunters will secure about 8,000 seals and the land catch will not be more than some 2,500 to 3,000 yearling males, which will all be killed for natives' food. This will make the census for 1908, about October 15, as follows:

Cows from 2 years to 11 years old............................... 10, 000

Bulls from 6 years to 18 years old (new bulls saved in 1905 come in)........... 400

Pups................................................ 9, 000

Two-year-olds (all spared) . . . . . . . . . . . . . . . . . . . . . . . . . ${ }^{5} 500$

Yearlings:

Males $(3,000$ of them killed for natives' food)................. 4, 000

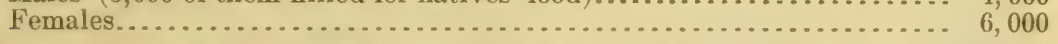

Fur seals of all classes alive on the Pribilof Islands October 15, 1908. . 29, 900

From 1908 on, if we save all the choice young male seals for breeders and kill nothing on the islands practically, then during 1909, 1910, 1911, 1912, 1913, 1914, and 1915 there will possibly be a variation of as much as 2,500 to 3,000 fewer, and then more cows and pups; between 1908 and 1915 there will never be less than 6,000 to 7,000 cows and 200 to 300 bulls; yet, with the steady following of 5 or 6 pelagic ressels, out of the 22 now engaged (in 1904), this life can not be increased, even though it can not be much more diminished.

In conclusion I desire to say that these facts and figures which I have cited above can not be successfully questioned by any evidence to the contrary; the deductions which I have drawn from these facts and figures I believe to be conservative aud reasonable.

Ilhen I study those figures purporting to be a complete census of the Pribilof herd during the season of 1904, and sent in to the Senate of the United States by the custedian of that he $\mathrm{d}$, on the 25 th ultimo, I am not surpriserl at them. I helieve that they are very near right.

But, Mr. Senator, what a pitiful driblet of life it is when contrasted with what it was when I surveyed it in 1872-1874. Then you saw an immense aggregation of over 4,500,000 fur seals on those Pribilof rookeries and hating grounds. where the agent of our Government last summer saw less than 200,000.

Is there good reason why this remnant of our herd, as it exists to-day, can not be be restored to that fine form and number recorded of it in 18,2 ? I say there is none.

If we will set aside and ignore the greed of our butchers of this life, and insist that the Government of Cireat Britain do the same to its butchers, and have this herd wholly within the keeping of both Governments hereafter, to the exclusion of all 
private gain ijonthe killing of that life on the land and in the seat, then its retoration ean be easily and surely brought about; otherwise it can never be.

Very sincerely, yours,

Hon. KNute NeLsox,

HENRY W. Eliote.

\section{United States Senate.}

At this point pernit me to call the attention of your commitee to the following significant fact: The first and only oflicial publicattion of the weights of fur sealskins, as taken on the Pribilof Islands, from the bolies of seals which are $1,2,3,4$, and 5 years of age, was marle in 1s\$1-18s4 by the Uniterl States Govermment in Special Bulletin No. 176, Lnited States Commission of Fish and Fisheries, page $\$ 1$. (See detailed figures in Exhibit - .)

Ao man or no official has ever disputed the accuracy of that table until in 1907, under date of December 1, an "estimate" table is submitted to the department by Special Agent Lembker, in which he attempts to certify a rearling skin into the class and weight of a 2-year-old. (See p. s4, S. Doc. No. 376, 60th Cong., 1st ses.s.)

This Lembkey table is a falsification of the facts. The official table, published in 1s\$1-1s\$t, as above cited, was the joint and careful work of four Cnited States Treasury agents, viz, Messrs. Bryant, Falconer, Lessen, and Elliott; and six of the lessee's agents, viz, Messi's. H. II. and H. W. McIntyre, William Wapus, Daniel TVebster, G. R. Adams, and T. F. Alorgan; and United States Commissioner Washburn Maynard, United States Navy.

This work of establishing that oflicial table of record weights of sealskins, as taken by those officials, was made by them and in full agreement, on the sealing grounds, during the seasons of $1872-1874$. It has never been disputed until that attempt made by Lembley, as above noted, in 1907.

To make this important and vital truth as to what is the real weight of a "yearling," a "'-2-year-old," and all older fur sealskins, I submit the following original detailed copy of the table which I made on the killing grounds of St. George Island, at the close of our official work, July 24, 1873 (on p. 168 of Special Bulletin No. 176, above cited, will be found a table showing the body growth of a fur seal from a pup up to old age, annually): 
Items of the veight and length whith follone the growth of a male fur sert (Cullortinus ursinus).

\begin{tabular}{|c|c|c|c|c|c|c|c|c|c|c|c|c|c|c|}
\hline Age. & $\begin{array}{l}\text { Blul } \\
\text { ber }\end{array}$ & & Fiesh. & $\mathrm{Vise}$ & ris. & Ski & & Bom & & $\begin{array}{l}\text { Fli } \\
\text { per }\end{array}$ & & $\begin{array}{l}\text { Weight } \\
\text { of whole } \\
\text { carcass. }\end{array}$ & $\begin{array}{l}\text { Length: } \\
\text { tip of } \\
\text { nose to } \\
\text { root of } \\
\text { tail. }\end{array}$ & Remarks. \\
\hline & Lbs. $C$ & $O z$ & Lbs. & Lbs. & $\mathrm{O} z$ & Lbs. & Oz. & Lbs. & $O z$ & Lbs. & $O z$ & Lbs. & Inches. & \\
\hline emonths... & 14 & & 10 & & & 2 & 11 & 2 & & 4 & & $40-42$ & 24 & $\begin{array}{l}\text { An average of } 50 \text { exam- } \\
\text { ples, taken on St. } \\
\text { Pau 1, November, } \\
\text { l872. }\end{array}$ \\
\hline Yearling.... & 4 & 0 & 14 & 10 & 01 & 4 & 8 & 3 & 0 & 6 & 0 & $40-42$ & 38 & $\begin{array}{l}\text { A mean of } 6 \text { examples, } \\
\text { taken on St. George, } \\
\text { July } 14,1873 \text {. }\end{array}$ \\
\hline 2-year-old... & $4 \frac{1}{2}-5$ & 0 & 24 & 13 & 0 & 5 & 8 & 4 & 10 & 7 & 0 & $58-59$ & 46 & $\begin{array}{l}\text { A mean of } 30 \text { examples, } \\
\text { taken on St. George, } \\
\text { July } 24,1873 \text {. }\end{array}$ \\
\hline 3-year-old... & 6 & 0 & 45 & 16 & 0 & 7 & 0 & 8 & 0 & 8 & 0 & $88-90$ & 52 & $\begin{array}{l}\text { A mean of } 32 \text { examples, } \\
\text { taken on St. George, } \\
\text { July } 24,1873 \text {. }\end{array}$ \\
\hline 4-5ear-old... & 14 & 10 & 60 & 24 & 0 & 12 & 0 & 9 & 12 & 8 & 8 & $128-135$ & 58 & $\begin{array}{l}\text { A mean of } 10 \text { examples, } \\
\text { taken on St. George, } \\
\text { July } 24,1873 \text {. }\end{array}$ \\
\hline 5-year-old... & 60 & 0 & 65 & 30 & 0 & 16 & 0 & 12 & 0 & 9 & 0 & $195-200$ & 65 & $\begin{array}{l}\text { A mean of } 5 \text { examples, } \\
\text { taken on St. George, } \\
\text { July } 24,1873 \text {. }\end{array}$ \\
\hline
\end{tabular}

Village of St. George, St. George Island, July $24,18 \% 3$.

With the aid of sammel Faleoner. Lnited states Treasury agent, I have been able to prepare this table of weights of the sereral lines of growth and propertions of the oreans which make up the broly of a fur stal; it is the result of rareful assortment and whorration, with this onission: While the rarcases were cut up and weighed " (o)ld," ret a rertain amount of blowel was lost in getting at the viscerat how much, of course, I am unable to say. In some of the specimens it was considerable, say a quart, others less than a pint.

The skrleton weights I asertainedi on st. Paul Island, July, lsi-2) (the sea fleats cleaned the bones for me), and the pups I ascertained also on st. Paul in November, 1872, while the natives were killing them for food.

HenRy W. ElLIOTT.

In the foregoing clear and indisputable showing of the officially published weights of "green" $1,2,3,4$, and 5 year old seal skins, when fresh taken on the Seal Islands of Alaskin. rour committee observes that any skin that weighs less than $5 \frac{1}{2}$ pounds when so taken is a skin that must be taken from a seal "under two rears of age," and when so taken is in riolation of the rules of the Department of Commerce and Labor.

I propose, for brevity and effect, to waive all mention at this point of the illegal killing of tens of thousands of rearling seals on the Pribilof Islands, by and with the sanction of the Government agents stationed thereon, sworn to prevent it, as it has been done from May 1,1904 , down to the expiration of this fur-seal lease, May 1, 1910. To quickly and surely fasten the charge of malfeasance on that officialism for that offense during the period just named, I will take the record of Mr. Nagel's men, as made by them last summer, when they killed 12,920 seals on the Pribilof Islands, and then falsely certificil that killing to the Gorernment, as made in strict obedience to the order of the Hitchcock rules of May 1, 1904.

On the 4th of February, 1911, Special Agent Lembker, introduced by Charles Nagel, appeared before the United States Senate Committee on Conservation of National Resources (Senator Joseph M. Dixon, chairman). In answer to the direct question of how many sealskins he had taken on the islands during the season of 1910 and under 
the rules of the department, he said he hat killed 12.9.20 souls. He then was asked if he had killed any umeler "2 years of age in that killing aforesaid. IIe replied that he had not. If then informed the committes that they had been sold in Lomolom, on December 17 last, and that they had solel at public auction, under the eres of the agents of the dereartment, ete. (See testimony before IT. S. Senate ('ommitter on (onservation of National Resondes, Feb. 4, 1911.)

Now, gontlemen, what do the oflicial records of that sale of 12,920 skins, as classified for sizes and values. declare? They actually declare the fact that Special Acrent Lembley killed at least 8,000$)$ yearling seals and certified them as seals "not under 2 years of age," to the committee, as above cited.

On pages 61-62 of the New Tork Fur Trade Review of February 1,1911 , is a cletailed transcript of the expert classification (officially returned to the Department of Commerce and Labor) made of this catch of 12,920 skins taken on the Pribilof Islands in June and July, 1910, by order of Charles Nagel, Secretary of Commerce and Labor, and sold in London December 17, 1910, under the personal charge of George M. Bowers, United States Fish Commissioner, etc.

This classification was made by the same experts that have assorted and classified all of the sealskins taken on the Pribilof Islands and sold in London annually since $1872-1874$. It is absolutely authentic and indisputable. It is summed up as follows, for brevity (the full details have appeared and are in the printed sales catalogue of Messrs. C. M. Lampson's Sons for December 17, 1910), to wit:

78 "smalls," or 3 -year-old seals, $7 \frac{1}{2}$ to 8 pound skins.

793 "large pups," or "short" 3-year-olds, and "long" 4-year-olds, $6 \frac{1}{2}$ to 7 pound skins.

3,775 "middling pups," or "short" 2-year-olds, and "long" yearlings, $5 \frac{1}{2}$ to 6 pound skins.

6,195 "small pups" or yearlings, $4 \frac{1}{2}$ to 5 pound skins.

1,809 "ex. sm. pups," or "short yearlings, $3 \frac{1}{2}$ to 4 pound skins.

270 (not well classified).

12,920 skins.

Out of which, 8,000 are indisputably the skins of seals taken "under 2 vears of age," and so taken in flagrant violation of the law and rules of the department as pledged to the Ways and Means Committee March 10, 1904, and ordered by the department May 1, 1904.

In this proof of that malfeasance, I submit that the committee on the conduct of affairs in the Department of ('ommerce and Labor, has a plain duty to perform.

I also submit a series of further and important detailed proof in the form of exhibits.

As to charge $I I$.-I beg to submit the following:

The causes which have resulted in the loss of more than $4,500,000$ fur seals, the property of the Government on the seal islands of Alaska, since $1882-1884$, are due to the following agencies, to wit:

First. The greed and power in official circles of our Government of private interests - the lessees of the seal islands. (See Exhibits -.)

Second. The ignorance, or worse, of our officialism in charge of that herd on the seal islands of Alaska. (See Exhibits -.)

On the 19th of November, 1874 , there were $4,700,000$ fur seals alive on the seal islands of Alaska. (See the official record of it, published 
by the U.S. Commissioner of Fish and Fisheries, Special Bulletin 176, 1883.)

On the 4th of February, 1911, Special Agent Lembkey, in charge of the seal islands of Alaska, in answer to the direct question put to him. of, "Do you know how many seals are now alive on the seal islands?" said, "I do not." "Are there 50,000?" he was then asked; he again said that he did not know.

(See testimony taken before U. S. Senate Committee on Conservation of National Resources, at hearing held in Senate Office Building; Washington, D. C., Saturday, Feb. 4, 1911.)

Here is, as abore cited, the indisputable and official proof of the fact that our fur seal herd has been depleted since 1883, down to date, of more than $4,500,000$ seals. That to-day a pitiful remmant of some 50,000 is all that survives of that vast herd of $1872-83$.

Think, also, gentlemen, for a moment, of the property loss to the Public Treasury of $4,500,000$ fur seals - at the least, a loss of more than $\$ 100,000,000$, for which we have nothing to show on the credit side of our books; we have received since 1870 , up to date, some $\$ 10,000,000$ gross revenue, but our expenses in that period have been nearly as much to defend and protect this private interest which has given us that revenue, and which has prevented any settlement of this question of suppressing the pelagic seal hunter's ruinous and cruel industry ever since 1890 up to date of May 1, 1910.

In submitting these detailed exhibits as above noted, in proof of this malfeasance on the part of the officialism concerned, I have to say in conclusion that abundant and overwhelming additional proof is in my possession and at your command for your information and use. I am, very truly, yours,

Washington, D. C., May 15; 1911.

Henry H. Ellioto. $95100-$ No. $1-11-3$ 
Exmbits Showing the Tiolation of the Law and Regulations orderein by the Governaent for tine Kiling of Fir Seals on the Seal Islaxds of Alaska.

Exmin A.-The "IItcheock Rules," ordered by the Secretary of commerce and Labor, May 1, 1904: "No seals under 2 years of age" can be lawfully killed for their skins

B.-The oflicial tables, showing the weights of skins of fur seals when taken from the bodies of fur seals $1,2,3,4$, and 5 years old on the Seal Islands; these tables published officially, 1881-1854, by the United States Fish Commission, and the Tenth Census United States of America.

C.-The official record of the sale of 5,000 skins in London, December 16, 1904, which were taken on the Pribilof Islands during June and July, 1904 , and of which 2,037 are the skins of yearlings and taken in open violation of the Hitchcock rules of May 1, 1904, and falsely certified by the department agents in charge as skins of 2-year-old seals."

D.-The official record of the sale of 14,674 skins in London, December 15 , 1905, which were taken on the Pribilof Islands during June and July, 1905, and of which 6,918 are the skins of yearlings, and taken in open violation of the Hitchcock rules of May 1, 1904, and again falsely certified to the department as "not. under 2 years of age" skins by its own sworn agents in charge of this work.

E.-The official record of the sale of 14,446 skins in London December 14 , 1906, which were taken on the Pribilof Islands, during June and July, 1906 , and of which 6,837 are the skins of yearling fur seals, and taken in open violation of the Hitchicock rules of May 1, 1904; and again falsely certified to the department, as the skins of seals "not under 2 years of age," by the sworn agents of the department in charge of the seal islands.

F.-The official record of the sale of 12,920 fur-seal skins in London December 17, 1910, which were taken on the Pribilof Islands during June and July, 1910, out of which 8.000 sl:ins are the skins of yearling fur seals, and all taken in deliberate and gross violation of the Hitcheock rules of May 1, 1904; and again are falsely certified to the department as skins "not under 2 years of age," by United States Fish Commissioner Bowers and his subordinate agents on the seal islands.

G.-Letters fully advising the Secretary of Commerce and Labor of the fraudulent killing of seals on the Pribilof Islands done by his agents in violation of law, and to all of which no response has ever been made, viz: From December 19, 1906, up to date of May 27, 1910, inclusive.

H.-Letter advising the President of the United States of fraudulent killing of fur seals on the Pribilof Islands, and inclosing a review of the salient errors of the Sims report, dated December 9, 1906.

I.-Proof of fraud and perjury uttered by lessees of seal islands to gain their lease, as submitted to the Presideni, July 12, 1909, and relerred by him to Department of Commerce and Labor, July 29, 1909.

$$
\text { Wasmington, D. C., May } 18,1911 .
$$

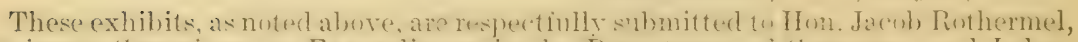
chairman (ommittee on Expenditures in the Department of Commeree and Labor, for the information and use of said committee by 


\title{
EXHIBIT A.
}

[Senate Document No. 114, Fifty-eighth Congress, Third session.]

\author{
Departant of Commerce and LABOR, \\ Office of the Secretary, \\ Washington, January 24, 1905.
}

SIr: In compliance with the terns of a resolution adopted in the Senate of the United States, under date of January 23, 1905, directing the Secretary of ('ommerce and Labor "to furnish, for the information of the Senate, copies of all regulations and instructions given by him to the agents of the department in charge of affairs on the seal islands of Alasks, and copies of all the reports to the said devartment which said agents have made during the season of 1904 , relative to the condition and management of the fur-seal herd of Alaska," I have the honor to transmit herewith copies of the letters of instructions issued by the department on May 1, 190t, for the guidance of the agent in charge of the seal islands of Alaska, and also a copy of a preliminary report that was adclressed to the department on August 12, ]904, by the agent in charge, relative to the conduct of affairs on the islands during the year 1904.

Uj to the present time the final detailed report of the agent for the year mentioned has not been received.

Respectfully,

The President of the Senate.

\section{H. Metcalf, Secretary.}

\section{Department of Commerce and Labor, OfFice of the Chief Clerk, Washington, May 12, 1904.}

Dear Sir: I inclose herewith department letter of May 1, 1904, embodying your instructions for the coming season as agent in charge of the seal islands.

Three copics of the letter of instructions are also inclesed, one of which you will please deliver to each of the assistant agents at the islands.

By to-ray's mail I shall forwarcl a copy of the letter of instructions to the North American Commercial Co., Mills Building, San Francisco, Cal.

Very truly, yours,

Mr. W. I. LeMB KEY, Agent in Charge of Seal Islands,

Department of Commerce and Labor.

F. H. Hттснсоск, Chief Clerk.

MAY 1, 1904.

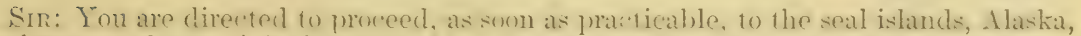
and restme change of the intrests of the foremment thereon. Assistant. Igent James Judge, who jis now at his home in ('olumbus, ()hio, will be instructed to aceompany You, and both of youl should take mastage to the islands on the steamer of the Vorth American Commercial Co. leaving San Francisco on or about the 21st instant.

You will make such assigmment of the assistant agents during the coming saling seasm as in your opinion will subserve the best interests of the service and the welfare of the mative inhahitants, notifying the lepartment of vour artion in this regard.

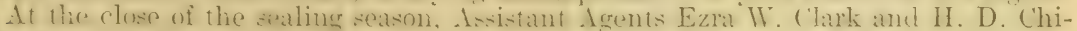

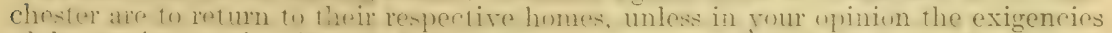
of the service require either (1) both of them to remain on the is lands during the coming winter, in which event you will instruct them accordingly.

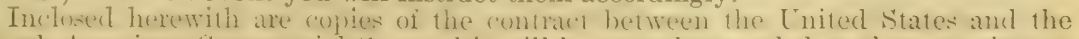
North American ('ommercial ('o., and it will be your duly and that of your assistants 
to see that its yovisions are enforeed and that the rights of the ciovernment and those of the lessees are duly protected.

Shomld a difference of opinion arise at any time between yourself and the representatives of the company in respect to a matter of arlministration on the islands, your decision must govern, but in all such rases you should request the superinlendent of the company ofo fumish a written statement of his views on the question involved, and this statement should be transmitted to the department, with an expression of your own views, at the earliest practicable moment.

Ounta.-Ii the conditions of the herd will permit, the lessees may be allowed to take during the season of 1904 as many as 13,000 male seals of the proper age on the island of it. Paul, and as many as 2,000 on the island of St. George, but not more than the number sperified in either case. The numbers to which the quotas of the two islands are thus limited shall be inclusive of any skins accepted by the company from food drives made prior to the present sealing season. No seals shall be taken that are over 4 years of age, nor shall any seals be taken that are under 2 years of age. ${ }^{1}$

In order to remove all doult as to the reservation of a sufficient number of male seals for the perpetuation of the herd, you are instructed to release from the best seals appearing in the first drives of the season not less than 1,000 3-year-old males and not less than 1,000 2-year-old males. Of the 3-year-olds and the 2-year-olds to be reserved, 800 of each shall be released on the island of St. Paul and 200 of each on the island of St. George. The seals thus released are to be marked in such a manner as will make them readily recognizable throughout the season, and under no circumstances are they to be taken by the lessees. ${ }^{1}$

Killing secism. - The killing season should begin as soon after the lst of June as the rookeries are in condition for driving. Seals shall not be killed by the lessees later than July 31. No seals whatever shall be taken during the stagey season. The killing of pups for food for the natives, or for any other purpose, is not to be permitted.

Seals for food. - The number of seals to be killed by the natives for food during the fiscal year beginning July 1, 1904, shall not exceed 1,700 on the island of St. Paul and 300 on the island of St. George, and no seals shall be taken for this purpose that are over 4 years of age or under 2 years of age, nor any of the 3 -year-olds or 2 -year-olds reserved during the lessees' killing season under the instructions given above.

Driving. - The representatives of the company on the islands shall be required to give notice on the day preceding that on which they desire to make a drive of the seals, stating the name of the rookery selected, such notice to be subject to your approval. A representative of the Government should be present on the killing grounds in each instance to superintend the killing. If at any time the methods employed in driving or killing appear in your judgment to be faulty or detrimental to the seal herd, you should see that such methods are immediately corrected, indicating to the representatives of the company what changes are to be made.

Killing grounds. - As heretofore, you should establish on each of the islands killing grounds that can be reached by the shortest possible driver; provided, however, that such killing grounds must be at places sufficiently distant from the rookeries to prevent annoyance from the decaying carcasses.

Acceptance of skins. - In an opinion dated Narch 8, 1902, it was held by the Solicitor of the Treasury that the lessees have no right to reject any of the skins taken from the seals they have selected for killing. You will therefore see that all such skins, regardless of condition, are accepted.

Counting stins.-All the sealskins should be carefully counted in the salt houses in the presence of the department agent and of the representative of the company, and a receipt, in duplicate, in the following form should be prepared and signed by said agent and by the representative of the company:

$$
\text { ST. — IsLAND, - - }-190-
$$

We certify that there have been placed in the salt house in our presence sealskins.

\section{Agent, United States Department of Commerce and Labor.}

\section{Agent, North American Commercial Co.}

The original of the above receipt should be retained by the department agent, and the duplicate given to the representative of the North American Commercial Co.

At the close of the season, when the sealskins are again counted and shipped on board the company's steamer, the usual annual receipts should be signed by the captain of the steamer and the representative of the department.

1 That order has been violated from start to finish-tens of thousands of times. The Iondon sales clinch the proof of that guilt. 
Trading in stins.-The North American Commercial Co. has the exclusive privilege under its contracts of taking sealskins and fox skins on the islands of St. Paul and St. George, and you should see that no other company or person is allowed to trade with the natives for such shins.

Mcasures to prevent shipment of skins by natives. - To avoid the possibility of sealskins or fox skins being surreptitiously shipped from the islands, you are directed to continue the practice of examining all goods to be shipped by the natives, including baggage and persomal effects, and where barrels. casks, boxes, or other receptacles are used they should be closed under your supervision, after an examination of their contents, before being placed in the warehouse. No person shall be admitted to the space reserved for such merchandise in the warehouse without your consent. Any skins found concealed in packages to be shipped by the natives should be seized and held, subject to instructions from the department.

Census of seal herd.- You are expected to make a thorough examination into the condition of the seal herd during the coming season, and to make a careful count of the number of breeding seals, male and female, on the islands, and also a computation, as accurate as possible, of the number of seals not breeding, including idle bulls, half bulls, bachelors, and virgin females. A careful enumeration should also be made of the pups found dead at the close of the season, and such information as can be had regarding the causes of death reported.

Sculstins to be weighed.- Tou are instructed to have the skins of the seals taken by the lessees during the coming season carefully weighed, and to keep a record of the weichts for the information of the department. You should also weigh the skins of seals that are killed to supply food for the natives and record the weights. The natives may be required to assist as far as practicable in the work of weighing.

Tuking of foxes to be restricted. - Proper restrictions should be placed upon the taking of foxes during the coming season. You are directed to see that the number killed is not in excess of the vearly increase in these animals. If there seems to le danger of extermination on either of the islands, all killing on that island should be stopped.

Killing of sen lions to be limited.-The preservation of the sea lion rookeries on the islands is highly important. The killing of these animals should be limited to such number as is absolutely necessary in providing for the construction of "bidaras," or skin boats. Sea lion pups should not be killed for any purpose.

Care of the natives.-The care and welfare of the natives should receive your close attention, and you are directed to see that the lessees perform all of the obligations of their contract toward such natives. You should ascertain the prices charged at the company's stores, compare then with the prices at San Francisco, and report any instances where the natives are compelled to pay unfair prices. You should also inspect the articles supplied as to quality and quantity, and if they are in any manner deficient you should report the fact to the department.

Comperisution to natius for taking seulskins. - The compensation to be paid by the company for killing, salting, curing, bundling, and loading the sealskins on the company's steamer will be 50 cents for each skin. The money thus earned is to constitule a community fund for distribution among the natives, according to their respective classes. At the close of the sealing season, after a conference with the native chiefs, you will make such division of the fund among the intives, according to their classification, as is demed fair and just, and submit a report of such division, showing the amount apportioned to each native participating in the fund, which reprort should be accompanied by an indorsement from the native chiefs and the company's agent certifying that such funds have been credited to such natives on the books of the company.

liturns to natives under for contract.- Tnder the contract executed between the Secretary of the Treasury and the North American Commercial ('o. on May 2, 1900, this company named was granted the right to propagate the fur-bearing animal known as the blue for, on the islands of $\mathrm{St}$. Paul-and St. George, for a term of five years, the company to pay sj for every blue $\mathrm{ox}$ skin and $\mathrm{el}$ for every white fox skin obtained, these payments to be entered as a credit on the books of the company in favor of the natives, and to be arailable for their support, on orders drawn in their favor by the Government agents.

The amounts accruing to the natives under this contract are to be added to and form a part of the community fund, and are in the same numer to be credited to the natives on the books of the company.

I'ayment of natices' comings. - The amounts that are earned from the company by the natives for labor, other than sealing and foxing, are to be paid to them in cash, and you will instruct the representatives of the company accordingly. The funds earned from sealing and foxing, however, are to be disbursed upon order as heretofore.

The payment to the natives of money from the appropriation for their maintenance, upon the orders of the Government agent, is strictly prohibited. 
Articless that do not properly rome within the term "necestaries" should not be exposed for sale in the company's stores nor sold to the natives for the money they earn l)y labor:

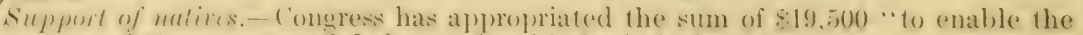
Secretary of fommeres and Labor to furnish fockl, fuel, and relothing to the native inhabitaints on the islands of st. Paul and sit. (ieorge, Alaskal," durine the fiscal year

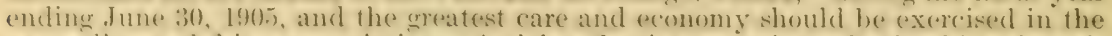
expenditure of this approp)riation. Articles of strict necessity omly should he issued. No expensive dress yoods, boots, or other articles are to be provided. The natives should be restricted to one pair of dress shoes each year and the women to one gond dress. Ginghans, calicoes, muslins, and similar inexpensive dress groods may be issued in reasonable quantities.

The supply of fuel for the use of the natives is jaid for from this appropriation, and the cust of stich fuel should not be overlooked in determining how much of the appropriation is available for other purposes.

In the distribution of these supplies no distinction is to be made between persons without means and those having small savings from previous years, but the earnings for the current year should be expended for necessaries, other than "food, fuel, and clothing," before any allowance is granted from the appropriation.

You will continue the plan, adopted under previous instruction, of issuing orders upon the company for such supplies as are required by the native inhabitants atter they have expended their current yearly earnings. At the end of the season, as heretofore, you will submit to the department the stubs of the orders given for use in verifying the accounts of the company.

Coul supply.- In a letter to the department, dated April 16, 1904, the North American Commercial ('o. has agreed to furnish during the coming season 175 tons of coal for use on the islands at \$20 per ton, including delivery on the beach, 90 tons to be delivered on St. Paul Island and 55 tons on St. George Island. This coal, with the So tons additional the company is required to furnish under the terms of its contract, will make available for all purposes a supply of 255 tons, and in its distribution the midows and orphans and aged and infirm inhabitants of the islands of St. Paul and St. George are to be included.

Of the 175 tons purchased from the company, you may make the following distribution:

St. Paul Island:

Tons.

For the Government house. ................................. 10

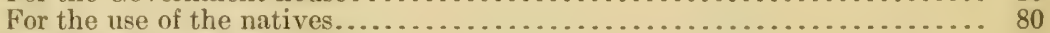

St. George Island:

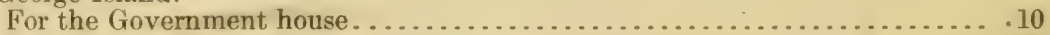

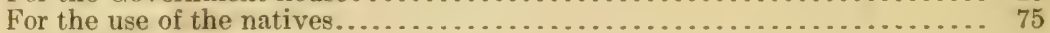

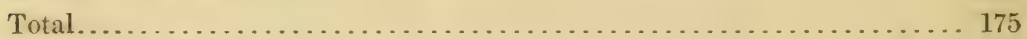

Of the 80 tons furnished by the company without charge under its contract, 50 tons mav be distributed to the natives of St. Paul and 30 tons to the natives of St. George.

Duellings for natives.- The agreement of the company in its contract to furnish the native inhabitants of the islands a sufficient number of comfortable dwellings and to keep such dwellings in proper repair should be strictly enforced. You are instructed to obtain from the representatives of the company, as soon after the close of the current fiscal year as practicable, a statement of the amount expended during the year in carrying out this requirement of the contract.

Schools for the natives. - You will require the schools for the native children to be maintained from September 1 to May 1 and to be opened five days in each week, the school hours to be from 9 o'clock a. m. to 3 o'clock p. m., with 1 hour recess at noon and 15 minutes' recess in the forenoon.

It will be your duty to see that the teachers appointed by the company are competent to teach the English languare and that they faithfully perform this duty. None but the English language shall be taught in these schools.

If the parents of the children on the islands desire to send them to the Jessie Lee Schonl at Inalaska, the department has no objection, provided no expenditure of public money is involved in their transportation to Unalaska or their maintenance and scholiny while there. This course will also be permitted, under the same conditions, in the case of orphan children for whom provision is now made by the company under its contract.

The amount expended by the company during the fiscal year for the maintenance of schools, in accordance with the requirements of its contract, should be ascertained and reported to the department. 
IIouse of worship and medicul affendenec.-You will also aseertain the company's expenditures during the year in mantaining a suitable house for roligious worship and in providing competent physictans and necestary medirines and medical supplies.

Widows, orphans, aged, and infirm.-The company is required by its contract to provide the necesaries of life for the widows and orphans and ared and infirm inhabitants of the islands who are mable to provide for themselves, and yon will see that this obligation is fully dischared. Is som as practicable after the closes of the current fiscal year rou will procure from the representatives of the company al statement showing the number of such inhabitants provided for during the year, and also the amount expended in making such provision.

Widows and orphans having small sums of money to their redit should not bo compelled to spend them and become wholly dependent hefore they are allowed to draw supplies under this provision in the company's contract. Surh sums, as well as similar aceounts held by other natives. may be drawn upon from time to time, howerer, with the ronsent and under the direction of the Government agent, for such reasonable articles as will contribute to the comfort of the persons supplying the funds.

Vutios to remer service. In consideration of the support eratuitously alforded the natives by the Government, you are directed to utilize their services, when not required by the company, in repairing roaks, cruarling their rookeries, and performing such other duties as seen desirable. This instruetion is not to he regarded, however, as relieving the company from its obligation to employ the natives, at a fair and just compensation, for all such work as they are fitted to perform.

Election of native chiff.-No interference should be permitted in the selection of their chiefs by the native inhabitants of the islands. If it should transpire, however, that persons manifestly unsuitable for the positim are chosen, jt will be your duty to interpose in the interest of arod government, and require the selection of proper persons, but such action should be taken only in extreme cases.

Sule of intoxicants probitrited. - The company agrees in its contract that it will not permit any of jts agents to keep, sell, give, or dispose of any distilled spirits or spirituous liguors or opium on either of the islands or the waters adjacent thereto to any of the native inhabitants, such person not being a physician and furnishing the same for use as a medicine. This obligation is to be rigidly enforced.

Ifunufacture of intoximats prohitited. - The brewing or distilling of intoxicating beverages on the island is prohibited. In the enforcement of this provision you are authorized to discontinue the sale, from the company's stores, of sugar, or of other articles entering into the manufarture of intoxicants, to any person who violates this order, or who is found to be intoxicated. Should intoxication become so general among the people ats to interfere with goxl government and jeoparlize the peace, you are authorized to discontinue altogether the sale of sugar, and of other articles entering into the manufacture of intoxicants, for such length of time as may appear wise.

licmoral for causc. - Should natives or other persons hecome so unruly or immoral in conduct as to endanger the peace and good government of the people, they should be removed from the islands, and the Pevenue-('utter Service will be instructed to render such assistance as may be necessary for that purpose.

Landing on the istruds restricted.-No persons other than (rovernment officers, representatives and employees of the North American 'ommercial ('o., and duly accredited representatives of the Russian ('hurch shall be allowed to land on the islands except by written authority from the dejartment. The permission granted representatives of the Russian ('hurch to visit the islands may be suspended, however, where its exercise is attempted by an improper person. Visitors to the iskands should not be permitted to inspect the rookeries; except under your supervision.

Information regarding affuirs on the islands. - No intornation regarding the seals or as to any other matter pertaining to the seal islands is to be given out by you or by any of the assistant agents. In applications for such information should be referrd to the department.

Conelusion. - Should questions arise involving matters not covered by these instructions, it will be your dut y to report the facts to the department and to a wa it instructions except in cases requuiring inmediate decision. when you will take such action as sound judgment directs.

I (opy of these instructions should be fumished by you to each of the assistant agents on the seal islands for their information and guidance.

$$
\text { Respectfully, }
$$

Geo. B. Contelyou,

MIr. W. I. LEMBKEY,

Secretary.

Agent in Charge of Seal Islands, Department of Commerce and Labor. 
Departuent of Commerce and Labor,

Office of the Chief Clerk, Washington, May 12, 1904.

I) E.An Sin: With reference to the provision in your instructions prohibiting the lessees from killing any seals during the coming season that are under 2 years of age, you are directed in the enforcement of this recpuirement to fix upon 5! pounds as a minimum limit of weight for the skins to be taken.

It will be your duty to see that every possible precaution is exercised to prevent the killing of seals that yield skins under the weight mentioned.

Very truly, yours,

Mr. IV. I. LEMBKEY, Agent in charge of Seal Islands,

Department of Commerce and Labor.

\section{F. H. Hrтснсоск, Chief Clerk.}

\section{Departuent of Commerce and Labor,}

Office of the Chief Clerk, Wrashington, May 14, 1904.

DEAR SiR: I desire to remind you of the wish of the department to have a record kept for the coming season of the number of sealskins taken on the islands, as distinct from the number of skins shipped. You may please have separate records made for each island of the number of skins taken from seals killed by the lessees during the season and also of the skins taken from seals killed in food dives.

The importance of securing fuller statistics regarding the seals on the island of St. George has been already impressed upon you. The assistant agents on that island should be required to exert every possible effort during the coming season to make their counts of the seals as accurate and complete as the conditions will permit. The number of idle bulls on the islands should be counted, as well as the bulls having harems, and as accurate returns as possible should be made as to the number of breeding cows, and also as to the number of immature seals, including half-bulls, bachelors, and virgin cows.

For the proper enforcement of the regulation prohibiting the killing of seals during the coming season that are under 2 years of age it is desirable that the work of weighing skins called for by your instructions be done with great thoroughness and care, one of the objerts of such weighing being to see that no skins are taken that weigh less than 5. pounds, which is the minimum limit to be fixed upon in the enforcement of the regulations. Your assistants on St. George should be advised as to the importance of this work and directed to comply strictly with the instructions. You will please see that at least two of the six weighing instruments with which you have been provided are placed in the hands of your assistants on St. George.

Very truly, yours,

Mr. W. I. LEMBKEY, Agent in Charge of Seal Islands,

Department of Commerce and Labor.

\section{F. H. Нгтснсоск, Chief Clerk.}

\section{Departant of Commerce and Labor,}

Office of the Chief Clerk,

Washington, May 14, 1904.

DEAR SIR: Pending the arrival on the islands of the clipping apparatus that is to be provided for experiment in marking the 2-year-old and 3-year-old seals to be reserved from the killing, it is expected that you will employ the method agreed upon of singeing out a spot in the fur on the top of the seal's head with the branding irons. In marking the fur by this method care should be taken not to burn into the skin of the animal.

Upon the receipt of the clipping apparatus you will please give it a sufficient test to determine its practicalility, and if it proves to be successful it should be substituted for the branding irons.

Very truly, yours,

Mr. W. I. LEMBKEY,

Agent in Charge of Seal Islands, Department of Commerce and Labor.

F. Н. Нrтснсоск, Chief Clerk. 
Office of Agent in Charge Seal Fisheries, St. Paul Island, Alaska, August 12, 1904.

DEAR SrR: I have to make the following summarized report of the condition of affairs on the seal islands of Alaska during the sealing season ended July 31, 1904:

The following number of seals was killed during the season by the lessee on its quota:

St. Paul............................................... 8,732

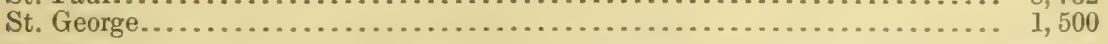

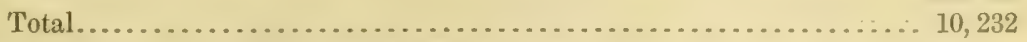

The following number of seals was killed for food before and after the regular sealing season or left on hand from previous seasons:

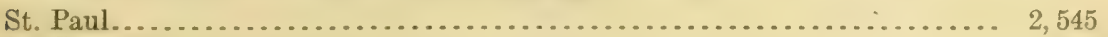

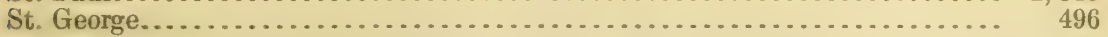

Total.............................................. 3, 041

The figures for St. Paul include 140 skins taken for food on August 9, 1901.

The following shipment of skins will be made by the company this fall:

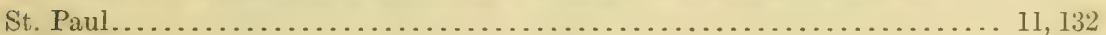

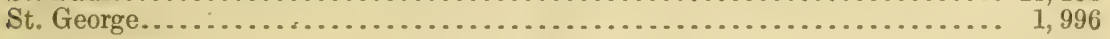

Total............................................ 13, 128

The lessee's quota of 15,000 skins was not filled for the reason that a sufficient number of seals of proper size was not present.

The following number of bachelors was branded this spring:

\begin{tabular}{|c|c|c|c|c|}
\hline & Islands. & $\begin{array}{l}\text { 2-year } \\
\text { olds. }\end{array}$ & $\begin{array}{l}\text { 3-year } \\
\text { olds. }\end{array}$ & $\begin{array}{l}\text { 4-year } \\
\text { olds. }\end{array}$ \\
\hline \multirow{2}{*}{\multicolumn{2}{|c|}{$\begin{array}{r}\text { St. Paul.... } \\
\text { St. George. } \\
\text { Total. }\end{array}$}} & $\begin{array}{l}800 \\
200\end{array}$ & $\begin{array}{l}800 \\
200\end{array}$ & $\begin{array}{l}50 \\
\cdots\end{array}$ \\
\hline & & 1,000 & 1,000 & 50 \\
\hline
\end{tabular}

Branding was completed on St. Paul on June 25 , and on St. George July 2 .

The number of breeding bulls, with harems and idle bulls, found this summer on both islands was as follows:

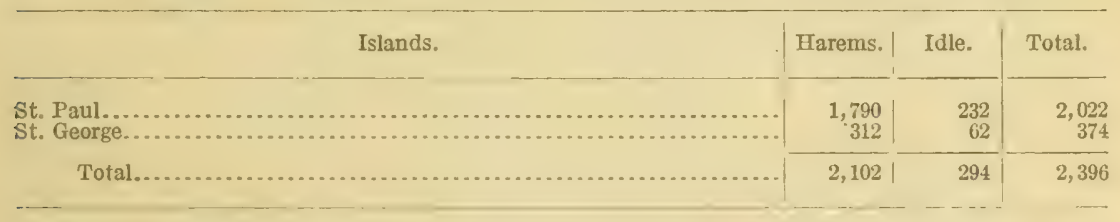

The counts of pups on both islands at the end of the season of 1901, with a comparison of the counts for the season of 1903, follow:

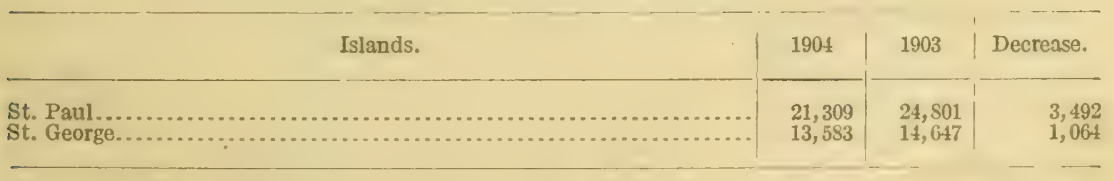


The consus oi breding eows and of bulls breeding and idle on the two islands for the seasons of 1903 and 190t, follows:

\begin{tabular}{|c|c|c|c|c|c|c|}
\hline \multirow{2}{*}{ Islands. } & \multicolumn{3}{|c|}{ Bulls. } & \multicolumn{3}{|c|}{ - Cows. } \\
\hline & 1903 & 1904 & Decrease. & 1903 & 1904 & Decrease. \\
\hline $\begin{array}{l}\text { St. Paul.... } \\
\text { St. George. }\end{array}$ & $\begin{array}{r}2,402 \\
1415\end{array}$ & $\begin{array}{r}2,022 \\
374\end{array}$ & $\begin{array}{r}382 \\
41\end{array}$ & $\begin{array}{l}82,649 \\
14,647\end{array}$ & $\begin{array}{l}74,002 \\
13,583\end{array}$ & $\begin{array}{l}8,647 \\
1,064\end{array}$ \\
\hline Total.. & .......... & 2,396 & 423 & 97,296 & 87,585 & 9,711 \\
\hline
\end{tabular}

Estimated.

The arenge harem during the past season (1904) was 39.83, as conpared with 40.29 during the seasum of $190 ; 3$. The lessening of the arerage harem is caused by the fact that the decrease in breeding cows during the interval between the seasons of 190:3 and 1!)0-t was greater than the decrease in bulls. On the area on which pups were comnted on st. Paul Island the decrease in harems was found to be 13.99 per cent, while the decrease in pups or breeding cows was 14.90 per cent.

During the season of 1904 there occurred in the various drives of the season, and including the food drive on the 9 th of August, 641 large rejections. 4.794 small rejections. and 1.888 rejections of branded seals. During the same period in 1903 the rejections were as follows: 912 large and 1,185 small. The increase in rejections from drives in 1904 was the result of the regulations restricting the killing to a minimum of $5 \frac{1}{2}$ pounds.

All skins taken on St. George during the sealing season, as reported by Agent Clark, were weighed. On St. Paul all but 145 skins taken during the sealing season were weighed. the latter number heing overlooked by the natives who gathered up the skins on the field for weighing. The bulk of the company's catch is skins of 2-yearolds, but a fair number of 3 -year-olds also were taken. No yearlings were included in the catch, and but few were seen in the drives.

One yearling was killed by me during the summer to determine the weight of that class of skins. The entire animal-a female-weighed 33 pounds, and its pelt weighed $3 \frac{1}{8}$ pounds.

A detailed report of the season's work will be made as soon as practicable after the departure of the company's vessel.

Very truly, yours,

Mr. F. H. Нıтснсоск,

W. I. LEMBKEY, Agent in Charge Seal Fisheries.

Chief Clerk Department of Commerce and Labor. 


\section{EXHIBIT B.}

Being the official tables fixing the record weights of skins of fur-seals as they are taken from the bodies of $1,2,3,4$, and 5 year olit fur seals on the seal lskands of Alaskia, officially prepared and alopted and published by the United states Gurermment in $1881-82$

These official tables have never been disputed by any competent officialism since they were published by order of the Secretary of the Treasury, in 1881-8\%, up to clate.

ANNUAL GROWTH OF AN AVERAGE FUR SEAL (CALLORHINUS URSINTS) SKIN-AS BORN AND BRED ON THE SEAL ISLANDS OF ALASKA.

The "pups" are all born annually, between Jume 6 and July 25; an immeneo majority of them being born between July 10 and 20.

Newborn and still "womb moist" pups weigh $7 \frac{1}{2}$ to 9 pounds then. When they are weaned, in November, and about to leave the islands for their winter migration in the North Pacific, and are $4 \frac{1}{t}$ to 5 months old, they weigh from 39 to 40 pounds each.

Between the 20th and 26th November, 1872, 10,550 pups were driven and "handled" for "natives" food" on the village killing grounds at St. Paul's Island. Out of this number so "handled" for sex selection, 5,976 were males, and were killed.

Five hundred carcasses, taken "as they ran," were weighed on this slaughter field, and declared an average of 39 to 40 pounils per carcass; some "runt " pups ran as low as 32 pounds; some well-grown ones went $u 1$ to 46 pounds. One hundred pups" skins taken from this killing, "as they ran," piled on a platform scale weighed 316 pounds, "clean skinned," thus showing an average weight of little more than 3 pounds; with the usual amount of blubber adherents left on them for salt curing they would weigh one-half to three-fourths of a pound each more per skin.

The following table of skin weights was the agreement made in 1874 by the Government agents and the lessees' agents as their standard for official and bisiness reports. It was officially published by the United States Fish Commission as Special Bulletin No. 176, and by the Tenth Census, United States of America, in 1881, under the direction of Prof. S. F. Baird, United States Commissioner of Fish and Fisheries, and on page 81 it appears as follows:

"Gradation of the Fur of (allorhinus ursinus.-The gradation of the fur of Callorhinus may, perhaps, be best presented in the following manner:

"One year old $\hat{\sigma}$, well grown, at July 1 of every season: Fur fully developed as to uniform length and thickness and evenness of distribution; it is lighter in color and softer in texture than hereafter during the life of the animal; average weight of skin as removed by the sealers from the carcass, $4 \frac{1}{2}$ pounds.

"Two year old $\hat{\sigma}$, well grown, at June 1 of every season: Fur fully developed as to even length and thickness and uniformity of distribution; it has now attained the darker buff and farn color, sometimes almost brown, which it retains throughout the rest of the life of the animal; it is slightly and perceptibly firmer and stiffer than it was last year, not being at all 'fluffy' as in the yearling dress now; average weight of skin as taken from the body, $5 \frac{1}{2}$ pounds.

"Three year old $\delta$, well gromn, at June 1 of every seas:on: Fur fully developed as to even length, but a shade longer over the shoulder, where the incipient 'wig' is forming; otherwise perfectly uniform in thickness and even distribution; this is the very best grade of pelt which the seal affords during its life; average weight of skin as taken from the body, 7 pounds.

"Four year old $\delta$, well grown, at June 1 of every season: Fur fully developed as to even length, except a decided advance in length and perceptible stiffness over the shoulder, in the 'wig;' otherwise perfectly uniform in thickness and even distribution; this grade is almost as safe to take and as good as is the 3-year-old; average weight of skin as removed, 12 pounds.

"Five year old $\delta$, well grown, at May to June 1 of every season: Fur fully developed, but much longer and decidedly coarser in the 'wig' region; otherwise uniform in thickness and distribution; the coarseness of the fur over the shoulders and clisproportionate length thereon destroys that uniformity necessary for rating Al in the market; in fact, it does not pay to take this skin; average weight, 16 pounds. 
"Six-year-old $\delta$, well grown, from May to June 1 of every season: Fur fully developed, still longer and stiffer in the "wig' region, with a slightly thinner distribution over the post-clursal region, and shorter; this skin is never taken-it is profitless; average weight, 25 pounds.

"Seven-year-old and upward $\delta$, from May to June 1 of every season: Fur fully developed, but very unevenly distributed, being relatively scant and short over the posterior dorsal recion, while it is twice as long and very coarse in the covering to the shoulders experially and the neck and chest. Skins are valueless to the fur trade; weights, 45 to 60 pounds.

"The' analysis, as above, is a brief epitomé of the entire subject; only, at should be added that the female skins are as finely furred as are the best grades of the males; and also, that age does not cause the quality of their pelage to deteriorate, which it does to o marked an extent in the males. But, taking them into consideration is entirely out of the question, and ought to be so forever.

"The fortal coat of the pup is composed of coarse black hair alone, the underwool not at all developed, when this is shed and the new coat put on in September and October, it is furred and haired as a yearling, which I diagnose above; this pelage has, however, no commercial value.

"All the skins taken by the company for the last eight years have been prime skins, in the fair sense of the term; but all the sealskin sacques made therefrom have not been of the first quality, by any means.

"In order that the rules and regulations and the law governing and protecting the interests of the Government on these islands may be fully understood, I embody them in the appendix." 


\section{EXHIBIT C.}

\section{[See recapitulation on p. 51.]}

C. M. Lampson \& Co. exposed to sale by auction at the College IIill public sale room on Friday, December 16, 1904, at 10 o'clock precisely, the following goods, viz, 20,000 skins salted fur seal, "Alaska," 86 skins salted fur seal, "Alaska." (Prompt, December 30, 1904.) The purchasers are particularly requested to have some one in attendance to superintend the counting, as no claim for deficiencies can bo allowed after the goods have been counted and delivered from the warehonse.

\section{CONDITIONS OF SALE.}

First. The highest bidder to be the purchaser.

Second. The purchasers shall have an allowance of $£ 210$ s. per cent for discount, and shall pay $2 \mathrm{~s} .6 \mathrm{~d}$. for each lot, together with a brokerage of oue-half per cent to the selling brokers and a deposit of 25 per cent on the amount of their purchase, if required to do so at the time of purchase.

The deposit must in any rase be paid in full on or hefore the prompt day, and in case of default (C. II. Lampson \& Co. are to be at liberty to resell any such lot or lots without further notice, and the buyer is to make good to them the deficiency (if any) of such resale, togrether with all expenses, in addition to forfeiting any pairt of the deposit which may have been pairl; and should the gonds sell for more on such resale than at the present sale the surplus shall belong to C. M. Lampson \& Co.

Third. From the day of sale interest at the rate of 5 per cent per annum will be allowed on all payments made in anticipation of the prompt.

Fourth. All payments (except the charge for cold storage) to be made to the selling brokers, who will give orders for the delivery of the goods so paid for.

Fifth. The goods to be taken with all faults and to be paid for on or before the prompt day; but should any of the purchasers wish to delay clearing any of their goods they shall have the option of doing so on the following terms:

The amount of the purchase shall be ascertained and a deposit of not less than 25 per cent therenn paid to the selling brokers on or before the prompt day.

Interest at the rate of 5 per cent per annum will be charged on the amount unpaid from the prompt day to the day of payment.

Payment shall be made in full, with intrest, nine months from the day of sale, say, the 16th day of September, 1905, when the goods shall be cleared and taken away.

C. M. Lampson \& Co. are to be at liberty, as soon as they may think proper, to resell, without further notice, any goods which have not been cleared by the buyer on or before the 16th day of September, 1905, and the said buyer is to make good to them the deficiency (if any) of such resale, together with all expenses, in addition to forfeiting the deposit of 25 per cent, and should the goods sell for more on such resale than at the present sale the surplus shall belong to C. M. Lampson \& Co.

Sixth. The selling brokers will not recognize or act upon any notice from a purchaser of the transfer of any gnods (purchased by him) to another party, unless they are satisfied as to the responsibility of such other party, and then only on the understanding that such other party accepts the goods subject to the sale conditions.

Seventh. That such of the purchasers as shall leave their goods in C. M. Lampson \& Co.'s warehouse (whether wholly or partially paid for after the prompt day), shall pay them on delivery of the goods, for cold storage, 1s. and $6 \mathrm{~d}$. per $₫ 100$ on the amount of purchase for each week or part of a week from the prompt day until the goods are taken away from the cold store.

Eighth. That C. M. Lampson \& C'o, being partners in the firm of C. M. Martin of Sons, agree to consider any goods placed in the hands of that firm for manufacturing purposes as being still in their own custody on condition, however, that the skins shall not be drawn away from the cold store to the Alaska factory until Messrs. C. IV. Martin \& Sons are ready to commence manufacturing them.

Ninth. All goods, whether paid for or not, shall be at the risk of the purchasers from the day of sale, but they will be insured against fire free of charge until delivered under the conditions of C. M. Lampson \& C'o.'s policies with fire insurance companies. 
Tenth. Should any dispute arise respecting the sale of any lot, the same shall be put up again and resold; and should any difference arise between any two or more buyers, the same shall be left to the decision of the selling broker.

Eleventh. No claims for deficiencies will be allowed by ('. M. Iampson \& Co. after the groods have been delivered from their warehouse, nor do the sellers hold themselves responsible for the descriptions in this catalogue.

The selling brokers will deliver to the buyers on the morning following the sale a contract for the goods purchased, and the selling brokers will consider such contracts as accepted by the buyers, unless exception is taken to them within 24 hours of delivery of same.

\section{In cold storage at Southeastern Wharf (snmples at 6.4 Qucen Street, E. C.), 20,000 stins} salted fur seal, Alaska.

[At per skin, to advance 1s.]

[Buyers are requested to note that all skins are stamped $\mathrm{L}$ A on the right cheek.]

1903 catch................ Lot 1

$2 \quad 190$

3192

$4 \quad 192$

5193

$6204 /$

1904 catch................. Lot 7

$$
8
$$$$
9
$$

1903 catch................. Lot 10

11

12

13

14

15

16

17

18

19

20

21

1904 catch................. Lot 22

23
24
25
26
27
28
29
30

$189 /$

13 Middlings, 4-year-olds, 11 to 12 pound skins.

65 Middlings and smalls, short 4-year-olds and long 3year-olds, 9 to 10 pound skins.

70 Smalls, 3-year-olds, 7 to 8 pound skins.

70

70

76

70 Unhaired and dressed (A).

(3 Middlings and smalls, "short" 4 -year-olds and "long" 3-year-olds.

70 Smalls; 3-year-olds.

199/ $\left\{\begin{array}{r}3 \\ 70\end{array}\right.$

199/ $\left\{\begin{array}{r}2 \\ 40\end{array}\right.$

179/ 80 Large pups, 2-year-olds, 6pound skins.

$1851 \quad 80$

186/ 80

188180

189) 80

189/ 80

189/ 80

189/ 80

189/ 80

189/ 80

189) 61

200/ 80 Unhaired and dressed (B).

194) 80 Large pups, 2-year-olds, 6pound skins.

194/ 80

194/ 80

194/ 80

194! 80

194/ 80

194/ 80

194/ 80

194/ 53 
In cold storage at Southeastern ITharf (samples at 64 Qucen Street, E. C.), 20,000 stins salted fur seal, Alaska-Continued.

1903 catch................. Lot 31

61

1904 catch Lot 67

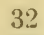

33

34

35

36

37

38

39

40

41

42

43

44

45

46

47

48

49

50

51

52

53

54

55

56

57

58

59

60

62

63

64

65

66

$148 /$

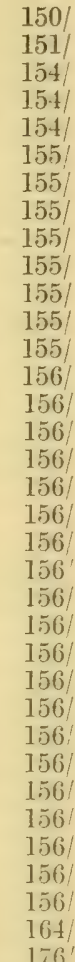

156

68

69

70

71

7.

73

74

i.)

76

7

is

$7 ?$

s0

S1

S.

83

84
90 Middling pups are the "short" 2 -year-olds and "long" yearlings, 5-pound skins.

90

90

90

90

90

90

90

90

90

90

90

90

90

90

90

90

90

90

90

90

90

90

90

90

90

90

90

90

90

90

90

90

it

90 Unhaired and dressed (D).

90 Dressed, dyed, and machined (C).

90 Middling pups are the "short" 2-year-olds, and "long" yearlings,

$\begin{array}{ll}156 & 90 \\ 156 & 90 \\ 156 / & 90 \\ 156 / & 90 \\ 156 & 90 \\ 1.56 & 90 \\ 1.55 & 90 \\ 1.55 & 90 \\ 1.55 & 90 \\ 1.54 & 90 \\ 1.55 & 90 \\ 15.5 & 90 \\ 1.55 & 90 \\ 15.5 & 90 \\ 1.55 & 90 \\ 1.55 & 90 \\ 15.5 & 6.3\end{array}$

90

90)

90

90

90

90

90

90

90

90

90

90

90 
In cold storage at Southeastern Wharf (samples at 6.4 Queen Strect, E. C.), 20,000 stins salted fur seals, Alaska-Continued.

1903 catch................ Lot $85 \quad 119 / 100$ "Small pups," "yearlings,"

$\begin{array}{lll}86 & 119 / \quad 100\end{array}$

$87 \quad 119 / \quad 100$

$88 \quad 119 / \quad 100$

$89 \quad 119 / \quad 100$

$90 \quad 119 / \quad 100$

$91-119 / \quad 100$

$92 \quad 119 / 100$

$93 \quad 119 / \quad 100$

$94 \quad 119 / \quad 100$

$95 \quad 119 / \quad 100$

$\begin{array}{lll}96 & 119 / \quad 100\end{array}$

$\begin{array}{lll}97 & 119 / \quad 100\end{array}$

$98 \quad 119 / \quad 100$

$99 \quad 119 / \quad 100$

$100 \quad 119 / \quad 100$

$101 \quad 119 / 100$

$102119 / 100$

$\begin{array}{lll}103 & 119 / \quad 100\end{array}$

$104 \quad 119 / \quad 100$

$105118 / 100$

$106 \quad 117 / \quad 100$

$107 \quad 116 / \quad 100$

$108 \quad 116 / 100$

$109 \quad 116 / 100$

$110 \quad 116 / \quad 100$

$111 \quad 116 / 100$

$112 \quad 116 / 100$

$113 \quad 116 / 100$

$114116 / 100$

$115116 / 100$

$116 \quad 116 / 100$

$117 \quad 118 / 100$

118 117/ 100

$119117 / 100$

$120117 / 100$

$\begin{array}{lll}121 & 119 / \quad 100\end{array}$

$122119 / 100$

$\begin{array}{lll}123 & 119 / & 100\end{array}$

124 118/ 100

125 118/ 100

$126119 / 100$

$127119 / 100$

$128 \quad 119 / \quad 100$

$129119 / 100$

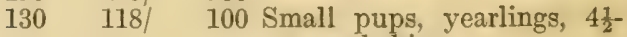

$131 \quad 119 / 100$

$132119 / 118$

133 124/ 100 Unhaired and dressed $(G)$.

134 134/ 100 Dressed, dyed, and machined $(\mathbf{E})$.

1904 catch................ Lot $135 \quad 120 / 100$ Small pups, yearlings, $4 \frac{1}{2}-$

$\begin{array}{lll}136 & 120 / & 100 \\ 137 & 120 / & 100 \\ 138 & 119 / & 100 \\ 139 & 119 / & 100 \\ 140 & 119 / & 100 \\ 141 & 119 / & 100 \\ 142 & 119 / & 100 \\ 143 & 119 / & 100 \\ 144 & 119 / & 100 \\ 145 & 119 / & 100\end{array}$


In cold storage at Southerastern Wharf (samples at 64 Qucen Strect, E. C.), 20,000 slins salted fur seal, Alaska-Continued.

1904 catch................. Lot $146 \quad 119$

$\begin{array}{lll}147 & 119 / & 100 \\ 148 & 120 / & 100 \\ 149 & 120 / & 122\end{array}$

1903 catch................. Lot 150

\section{1}

152

153

154

155

156

157

158

159

160

161

162

163

164

165

166

$\mathrm{I} 67$

168

169

170

171

172

173

174

175

1904 catch................. Lot 176

177

1903 catch................ Lot 178

1904 catch . . . . . . . . . . . . . . Lot 181

1903 catch................. Lot 182

183

1904 catch................ Lot 184

1903 catch................. Lot 185

186

187

188

189

1904 catch.................. Lot 190

191

1903 catch

Lot 192

193

191

1904 catch

Lot 195

1903 catch.
$106 /$

106/ 110

106/ 110

109/ $\quad 110$

109/ $\quad 110$

109/ 110

$109 / \quad 110$

$108 / 110$

107/ 110

106/ $\quad 110$

$105 / 110$

104/ 110

105/ 110

105.110

106/ 110

105/ 110

106/ $\quad 110$

$105 / 110$

106/ $\quad 110$

105 110

$105 / 110$

$105 / 110$

$105 /$

$105 /$

$110 /$

1.181

$106 /$

$105 /$

$86 /$

$115 /$

$119 !$

1181

$118 /$

$118 /$

121/

115

$115 /$

115

$115 /$

115

115

115 !

95 !

95

95 !

95 ।

79 ।

108

113

$\left\{\begin{array}{r}8 \\ 54\end{array}\right.$

96

96

96

95

96

128

127
Small pups, yearlings, $4 \frac{1}{2}$ pound skins.

Extra small pups, "short" yearlings, 4-pound skins.

110 Ex. small pups.

110 Unhaired and dressed (I).

110 Dressed, dyed, and machined (H).

110 Ex. small pups, "short" yearlings, 4-pound skins.

102 Ex. ex. small pups, "runts," yearlings, 3-pound skins.

f Middlings and smalls, low, etc.

54 Smallis, low, etc.

( 8 Middlings and smálls, low, etc.

29 Smalls, low, etc.

75 Large pups, low, etc.

75

87 Large pups, low, etc., 2-yearolds, 6-pound skins.

96 Middling pups, low, etc.

96 Middling pups, low, etc.

128 Small pups, low, etc.

150 Small pups, low, etc.

188 Ex. small pups, low, etc.

$$
95100-\text { No. 1-11-4 }
$$


In cold storage at Southeastern Wharf (sumples at 6.t Qucen Street, E. C.), 20,000 stins salted fur seal, Alaska-Continued.

1904 catch ............... Lot 197

1903 catch................. Lot 198

1904 catch................. Lot 199

1903 catch

Lot 200

201

202

203

1904 catch.................. Lot 204

1903 catch ................. Lot 205

206

207

208

1904 catch

Lot 209

1903 catch

Lot 210

211

212

22 Ex. small pups, low, etc., "short" yearlings.

1 Ex. ex. small pup, low, etc., short "yearling." The "runt" taken by United States Goyernment agent.

9 Middlings and smalls, cut, etc.

31 Smalls, cut, etc.

2 Middlings and smalls, cut, etc.

17 Smalls, cut, etc.

58 Large pups, cut, etc.

179/ 86 Large pups, cut, etc.

143/ 91 Middling pups, cut, etc.

$143 / 91$

143/ 91

143/ 88 Middling pups, cut, etc.

107/ 110 Small pups, cut, etc.

107/ 110

107/ 109

107/ 109

107 107 Small pups, cut, etc.

$\{12$ Extra small pups, cut, etc.

(114 Extra small pups, cut, etc.

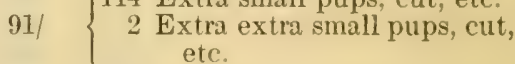
91) $\quad\left\{\begin{array}{r}113 \\ 2\end{array}\right.$

66/ 42 Faulty.

Eighty-six skins, salted fur seal, Alaska.

$$
\text { Lot } 213 \quad 106 /
$$

S6. Skins, 12 smalls, 18 large pups, 29 middling pups, 23 small pups, 4 extra small pups.

\section{SUMMARY AND ANALYSIS OF THIS SALE.}

Fifteen thousand of this sale brought over from catch of 1903 , and 5,000 from the catch of 1904, leaving 8,000 skins of the catch of 1904 to go over to the sale of December, 1905 . The prices have advanced in this sale 23 per cent over the prices of December, 1903.

Note.-Since only 5,000 of the catch of $190 t$ is offered in association with 15,000 of the catch of 1903 , the proportions of the catch of 1904 , as contrasted with the sizes of 1903 , can only be reached by multiplying the sizes of 1904 three times, so as to make the total 15,000 , or equal to that of 1903 . This makes the following contrast:

\begin{tabular}{|c|c|c|c|}
\hline & 1904 & 1903 & Remarks. \\
\hline 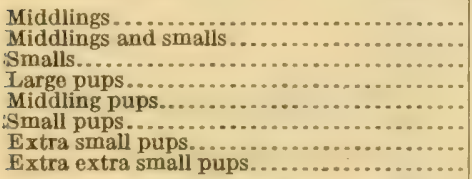 & $\begin{array}{r}0 \\
594 \\
144 \\
2,514 \\
5,109 \\
5,337 \\
771 \\
3\end{array}$ & $\begin{array}{r}13 \\
90 \\
495 \\
1,177 \\
3,969 \\
5,439 \\
3,273 \\
106\end{array}$ & $\begin{array}{l}\text { A loss in } 1904 \text { of } 13 \text { skins. } \\
\text { A gain in } 1904 \text { of } 504 \text { skins. } \\
\text { A loss in } 1904 \text { of } 351 \text { skins. } \\
\text { A gain in } 1904 \text { of } 1,337 \text { skins. } \\
\text { A gain in } 1904 \text { of } 1,140 \text { skins. } \\
\text { A loss in } 1904 \text { of } 102 \text { skins. } \\
\text { A loss in } 1904 \text { of } 2,502 \text { skins. } \\
\text { A loss in } 1904 \text { of } 103 \text { skins. }\end{array}$ \\
\hline
\end{tabular}

Or, in other words, this contrast shows that the restrictions imposed upon the killing and taking of skins in 1904 prevented the lessees from getting some 2.700 small skins which they would have taken under the regulations of 190:3; but at the same time they have increased their killing of the large skins about 2,500 over their proportion of such skins in 1903 . 
It may be that the balance of the catch of 1904 , some 8,000 skins, which is held over for the sales in December, 1905 , will not show up in the proportion assumed above; it may be that the run of small skins will be very much greater in it than appears in the run of the 5,000 classified and sold December 16, 1904.

JANUARY 5, 1905.

A. W. E.

Analysis of this Sale of Pribilof Fur-Seal Skins, December 16, 1904, in LONDON.

Sizes and ages:

Catch of 1904 (5,000 offered).

Number of skins.

4-year-old skins, or "middlings," 12 to 14 pound skins

"Short" 4-year-olds and "long" 3-year-olds, or "middlings and smalls,"

9 to 11 pound skins

3 -year-olds, or "smalls," 7 to 8 pound skins.

2-year-olds, or "large pups" "6-pound skins .........................

"Long" yearlings and "short" 2-year-olds, or "middling pups," $5 \frac{1}{2}$

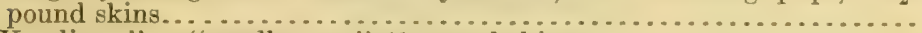

"Yearlings," or "small pups," 41 -pound skins...........................

"Short" yearlings, or "ex. small pups," $3 \frac{1}{3}$-pound skins .............

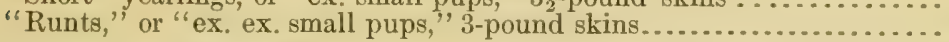

Total catch of 1904 .

Of which 2,037 are yearlings.

Sizes and ages:

Catch of 1903 (15,000 offered).

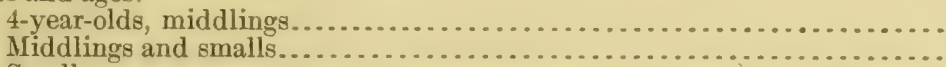

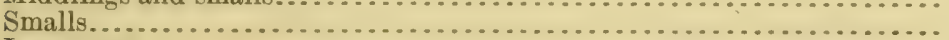

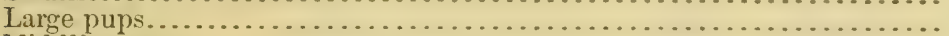

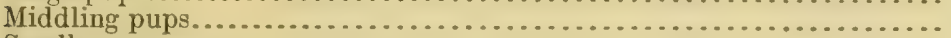

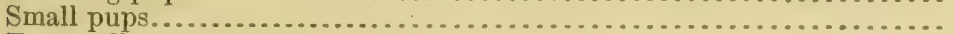

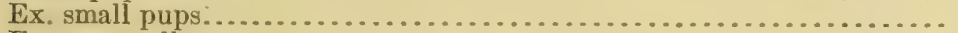

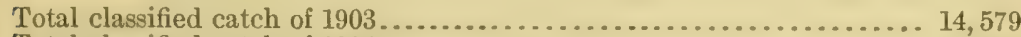

Total classified catch of 1904

The balance, 539 skins, not covered definitely in the catalogue as to size and season. 


\title{
EXHIBIT D.
}

\author{
[See recapitulation on p. 58.]
}

C. II. Lampion \& ('o. expored to sale by auction, at the c'ollege Hill public saleroom, on Friday, Decomber 15, 1905, at 10 o'clock precisely, the following goods, viz: 222.310 skins salted fur seal, Alaska; 100 skins salted fur seal, Alaska. (Prompt, Dec. 29, 1905.) The purchavers are particularly requested to have some one in attendanee to superintend the counting, as no clain for deficiencies can be allowed after the goods have been counted and delivered from the warehouse.

CONDITIONS OF SALE.

First. The highest bidder to be the purchaser.

Second. The purchasers shall have an allowance of $£ 210 \%$ per cent for discount, and shall pay $2 \div$. 6d. for earh lot, together with a brokerage of $\frac{1}{2}$ per cent to the selling brokers, and a deposit of 25 per cent on the amount of their purchase, if required to do so, at the time of purchase.

The deposit must in any case be paid in full on or before the prompt day, and, in case of default, C. M. Lampson \& ' 'o. are to be at liberty to resell any such lot or lots without further notice, and the buyer is to make good to them the deficiency (if any) of such resale, together with all expenses, in addition to forfeiting any part of the deposit which may have been pairl; and should the goods sell for more on such resale than at the present sale the surplus shall belong to C. M. Lampson \& C.

Third. From the day of sale, interest at the rate of 5 per cent per annum will be allowed on all payments made in anticipation of the prompt.

Fourth. All payments (except the charge for cold storage) to be made to the selling brokers, who will give orders for the delivery of the goods so paid for.

Fifth. The goods to be taken with all faults, and to be paid for on or before the prompt day; but should any of the purchasers wish to delay clearing any of their goods, they shall have the option of doing so on the following terms:

The amount of the purchase shall be ascertained and a deposit of not less than 25 per cent thereon paid to the selling brokers on or before the prompt day.

Interest at the rate of 5 per cent per annum will be charged on the amount unpaid from the prompt day to the day of payment.

Payment shall be made in full, with interest, nine months from the day of sale, say, the 15th day of September, 1906, when the goods shall be cleared and taken away.

C. M. Lampson \& ('o. are to be at liberty, as soon as they may think proper, to resell, without further notice, any goods which have not been cleared by the buyer on or before the 15th day of September, 1906, and the said buyer is to make good to them the deficiency (if any) of such resale, together with all expenses, in addition to forfeiting the deposit of 25 per cent, and should the goods sell for more on such resale than at the present sale, the surplus shall belong to ( $\div$. M. Lampson \& ('o.

Sixth. The selling brokers will not recognize or act upon any notice from a purchaser of the transfer of any goods (purchased by him) to another party, unless they are satisfied as to the responsibility of such other party, and then only on the understanding that such other party accepts the goods subject to the sale conditions.

Seventh. That such of the purchasers as shall leave their goods in C. M. Lampson \& ('o.'s warehouse (whether wholly or partially paid for) after the prompt day shall pay them on delivery of the gonds, for cold storage, Is. $6 \mathrm{~d}$. per $£ 100$ on the amount of purchase for each week or part of a week from the prompt day until the goods are taken away from the cold store.

Eighth. That ('. M. Lampson \& ('o., being partners in the firm of C. W. Martin d Sons, agree to consider any goods placed in the hands of that firm for manufacturing purposes as being still in their own custody, on condition, however, that the skins shall not be drawn away from the cold store to the Alaska factory until Messrs. (?. WV. Martin \& Sons are ready to commence manufacturing them. 
Ninth. All goods, whether paid for or not, shall be at the risk of the purchasers from the day of sale, but they will be insured against fire, free of charge, until delivered, under the conditions of C. M. Lampson \& ('o.'s policies with fire insurance companies.

Tenth. Should any dispute arise respecting the sale of any lot, the same shall be put up again and resold; and should any difference arise between any two or more buyers the same shall be left to the decision of the selling broker.

Eleventh. No claims for deficiencies will be allowed by C. II. Lampson \& (o. after the goods have been delivered from their warehouse, nor do the sellers hold themselves responsible for the descriptions in this catalogue.

The selling brokers will deliver to the buyers on the morning following the sale a contract for the goods purchased, and the selling brokers will consider such contracts as accepted by the buyers unless exception is taken to them within 24 hours of delivery of same.

\section{In cold storage at Southeastern Wharf (samples at 64 Queen Street, E. C.), 22,310 skins salted fur seal, Alaska.}

[At per skin, to advance 1s.]

[Buyers are requested to note that all skins are stamped L A on the right cheek.]

1904 catch................. Lot 1 1905 catch................. Lot 5

1904 catch................. Lot 8

190
2201

4 Short 4-year-olds, long 3-yearolds, 11-pound.skins, middlings and smalls.

70 3-year-olds, $8 \frac{1}{2}$ to 9 pound skins, "loaded " with $1_{2}^{\frac{1}{2}}$ to 2 pound blubber, smalls.

$233 / \quad\left\{\begin{array}{r}4 \\ 70\end{array}\right.$

$233 /\left\{\begin{array}{r}4 \\ 81\end{array}\right.$

235) 70 Unhaired and dressed (A).

( 2 Long 3-year-olds, short 4-yearolds, middlings and smalls, 11-pound skins.

70 3-year-olds, $8 \frac{1}{2}$ to 9 pound skins, smalls.

$\left\{\begin{array}{r}2 \\ 70\end{array}\right.$

$236 /$

$\left\{\begin{array}{l}70 \\ 6\end{array}\right.$

193/

80 Long 2-year-olds, short 3-yearolds, large pups, $6 \frac{1}{2}$ to 7 pound 14-ounce skins, "loaded" with 1 to $1 \frac{1}{2}$ pound blubber, cut. 
In cold storage at Southeastern Wharf (samples at 64 Qucen Street, E. C.), 22,310 skins salted fur seal, Alaska-Continued.

1905 catch.................. Lot $22 \quad$ 197/

23
24
25
20
27
28
29
30
31
32
33
3
35
36
37

$\begin{array}{ll}197 / & 80 \\ 197 / & 80 \\ 198 / & 80 \\ 198 / & 80 \\ 198 / & 80 \\ 198 / & 80 \\ 198 / & 80 \\ 198 / & 80 \\ 198 / & 80 \\ 198 / & 80 \\ 198 / & 80 \\ 198 / & 80 \\ 198 / & 80 \\ 198 / & 33\end{array}$

1904 catch................ Lot 37
1521

$\begin{array}{ll}38 & 152 / \\ 39 & 152 / \\ 40 & 152 / \\ 41 & 152 / \\ 42 & 152 / \\ 43 & 152 / \\ 44 & 152 / \\ 45 & 152 / \\ 46 & 152 / \\ 47 & 152 / \\ 48 & 152 / \\ 49 & 153 / \\ 50 & 152 / \\ 51 & 152 / \\ 52 & 152 / \\ 53 & 152 / \\ 54 & 153 / \\ 55 & 153 / \\ 56 & 153 / \\ 57 & 153 / \\ 58 & 153 / \\ 59 & 153 / \\ 60 & 153 / \\ 61 & 153 / \\ 62 & 153 / \\ 63 & 153 / \\ 64 & 161 / \\ 65 & 167 /\end{array}$

80 Large pups, long 2-year-olds, short 3-year-olds, $6 \frac{1}{2}$ to 7 pound 14 ounce skins average, "loaded" with 1 to $1 \frac{1}{2}$ pound blubber.

\section{0}

80

80

80 Middling pups, average for
2 -year-olds, 6 to $6 \frac{1}{2}$-pound skins, loaded with $\frac{1}{2}$ to 1 pound blubber cut.

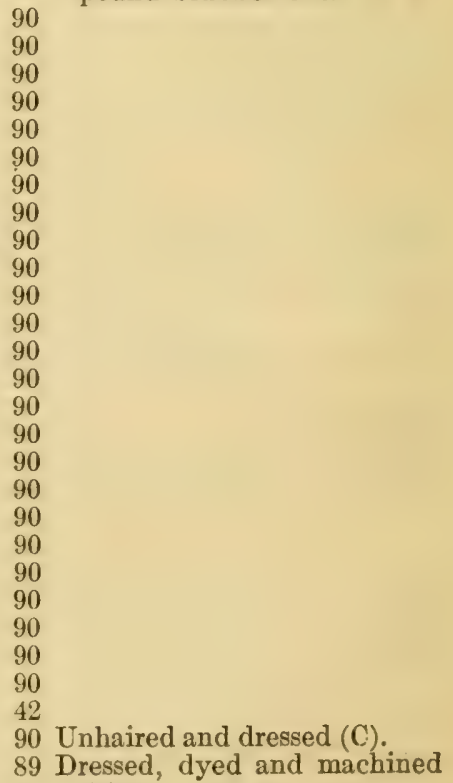
(4). 
In cold storage at Southeastern Wharf (samples at 64 Queen Strect, E. C.), 22,310 skins salted fuir seal, Alaska-Continued.

1905 catch................ Lot 66

147|

$\begin{array}{lll}67 & 147 ! & 90 \\ 68 & 147 ! & 90 \\ 69 & 147 ! & 90 \\ 70 & 147 ! & 90 \\ 71 & 147 ! & 90 \\ 72 & 147 ! & 90 \\ 73 & 147 ! & 90 \\ 74 & 147 ! & 9 \\ 75 & 147 ! & 9 \\ 76 & 147 ! & 9 \\ 77 & 147 ! & 90 \\ 78 & 147 ! & 9 \\ 79 & 147 ! & 9 \\ 80 & 147 ! & 9 \\ 81 & 147 ! & 90 \\ 82 & 147 ! & 90 \\ 83 & 147 ! & 90\end{array}$

$84 \quad 147 / 90$

$85-147 / 90$

$86 \quad 147 / \quad 90$

$\begin{array}{llll}87 & 147 / & 90\end{array}$

$88 \quad 147 / \quad 90$

$89 \quad 147 / 90$

$\begin{array}{lll}90 & 147 / & 90\end{array}$

$91 \quad 147 / \quad 90$

$92 \quad 147 / 90$

$\begin{array}{llll}93 & 147 / & 90\end{array}$

$94 \quad 147 / 90$

$95 \quad 148 / \quad 90$

$96 \quad 147 / \quad 90$

$97 \quad 147 / \quad 90$

$\begin{array}{llll}98 & 148 / & 90\end{array}$

$\begin{array}{lll}99 & 148 & 90\end{array}$

$100 \quad 147 / 90$

$101 \quad 147 / 90$

$102 \quad 147 / 90$

$103 \quad 147 / 90$

$104 \quad 147 / 90$

$105147 / 90$

106 147/ 90

$107 \quad 147 / 90$

108 147/ 90

109 147/. 90

$110 \quad 147 / 90$

111 147/ 90

112 147/ 90

$113 \quad 147 \mid \quad 86$
Tiddling pups, average 2-year-
olds, loaded with to 1 pound blubber cut, 6 to $6 \frac{1}{2}$-pound skins. 
In cold storage at Southenstern Wharj (samples at 6.4 Qucen Strect, E. C.), 22,S10 stins salted for seal, Alaska-Continued.

1904 catch................ Lot 114 117/ 100 Small pups, "short" 2-yearolds, "long" yearlings, "loaded" with $\frac{1}{2}$ to 1 pound blubber "cut," 5 to $5 \frac{1}{2}$ pound skins.

$\begin{array}{llll}115 & 117 & 100 \\ 116 & 117 & 100 \\ 117 & 117 & 100 \\ 118 & 117 & 100 \\ 119 & 117 & 100 \\ 120 & 116 & 100 \\ 121 & 116 / & 100 \\ 122 & 116 / & 100 \\ 123 & 116 / & 100 \\ 124 & 116 / & 100 \\ 125 & 116 / & 100 \\ 126 & 116 / & 100 \\ 127 & 116 / & 100 \\ 128 & 116 / & 100 \\ 129 & 116 / & 100 \\ 130 & 116 / & 100 \\ 131 & 116 / & 100 \\ 132 & 116 / & 100 \\ 133 & 117 / & 100 \\ 134 & 117 / & 100 \\ 134 & 117 / & 100 \\ 135 & 117 / & 47 \\ 136 & 123 / & 100 \text { Unhaired and dressed (D). } \\ 137 & 130 / & 100 \text { Dressed, dyed, and ma- }\end{array}$
chined (3).

1905 catch

Lot 138

$117 /$

$\begin{array}{lll}139 & 117 / & 100 \\ 140 & 117 / & 100 \\ 141 & 117 / & 100 \\ 142 & 117 & 100 \\ 143 & 117 / & 100 \\ 144 & 117 / & 100 \\ 145 & 117 / & 100 \\ 146 & 117 / & 100 \\ 147 & 117 / & 100 \\ 148 & 117 / & 100 \\ 149 & 117 / & 100 \\ 150 & 117 / & 100 \\ 151 & 117 / & 100 \\ 152 & 118 / & 100 \\ 153 & 118 / & 100 \\ 154 & 117 / & 100 \\ 155 & 117 / & 100 \\ 156 & 117 / & 100 \\ 157 & 117 / & 100 \\ 158 & 117 / & 100 \\ 159 & 117 / & 100 \\ 160 & 117 / & 100 \\ 161 & 117 / & 100 \\ 162 & 118 / & 100 \\ 163 & 118 / & 100 \\ 164 & 118 / & 100 \\ 165 & 118 & 100 \\ 166 & 118 / & 100 \\ 167 & 118 / & 100 \\ 168 & 119 / & 100 \\ 169 & 118 & 100 \\ 170 & 118 / & 100 \\ 171 & 118 / & 100\end{array}$
olds "c, "sort" to $5 \frac{1}{2}$ pound skins. 
In cold storage at Southeastern Wharf (samples at 64 Queen Strect, E. C. 1, 23,310 shins salted for seal, Alaska-Continued.

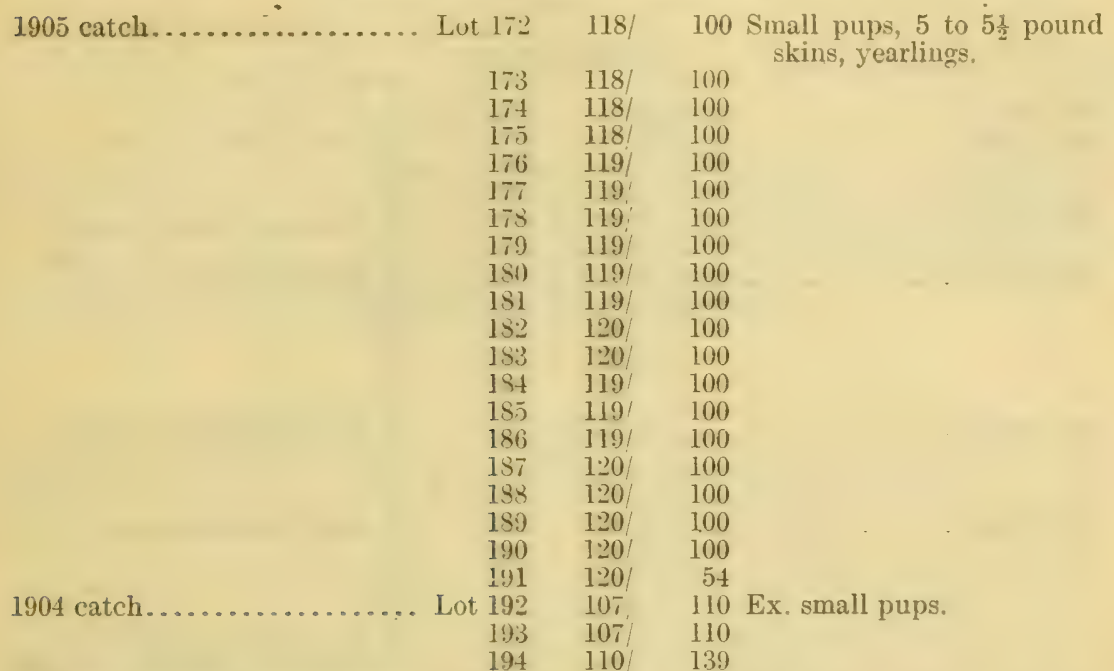

1905 catch............... Lot 19.5 $111 / 110 \mathrm{Ex}$. small pups, yearlings, $4 \frac{1}{2}$ to 5 pound 8 ounce skins.

$\begin{array}{rrr}196 & 111 & 110 \\ 197 & 111 & 110 \\ 198 & 112 / & 110 \\ 199 & 112 / & 110 \\ 200 & 112 / & 110 \\ 201 & 112 & 70\end{array}$

1904 catch.............. Lot 20

1905 catch............... L ot 203

1904 catch............... Lot 204

205

1905 catch.............. Lot 200

207

208

209

1904 catch................ I.ot 210

211

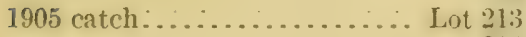

214

215

216

1904 catch

Lot 217

$21 \mathrm{~s}$

1905 ratch

L.ot 219

$2: 0$

221

1904 catch

Lot 222

1905 catch

Lot 223

1904 catch
$128 /$

130 :

125

125

125

126

127

127

122

$122 /$

$121 /$

1233

$123 /$

$123 /$

$123 /$

$100 /$

100

1021

103 :

103

85)

SE!

190 f1 Middlings and smalls, low, etc.

47 Smalls, low, etc.

$\int$ Middlings and smalls, low, etc.

71 Smalls, low, etc.

71 Large pups, low, etc.

70

81 Large pups, low, etc.

81

80

80

103 Middling pups, low, etc.

103

102

97 Middling pups, low, etc.

97

97

96

121 Small pups, low, etc.

120

89 Small pups, low, etc.

89

88

$\int 34$ Ex. small pups, low, ete.

1 Ex. ex. small pup, low, etc.

47 Ex. small pups, low, etc.

4 Middlings and smalls, cut, etc.

28 Smalls, cut, etc. 
In cold storage at Southeastern Wharf isamples at 64 Queen Strect, E. C.1, 22,310 skins salted fur seal, Alaska-Continued.

1905 catch................ Lot 225

1904 catch. . . . . . . . . . . . Lot 226

1905 catch................. Lot 227

228

229

1904 catch................ . Lot 230

231

1905 catch................. Lot 232

233

234

235

236

1904 catch................ Lot 237

238

1905 catch ................ Lot 239

240

241

242

243

244
$192 /$

$183 /$

187/

$186 /$

$186 /$

$144 /$

$144 /$

$144 /$

144/

145 /

$145 /$

$145 /$

$110 /$

111/

111/

$111 /$

$112 /$

$111 /$

99/

$83 /$

6 Middlings and smalis, cut, etc.

\section{Smalls, cut, etc.}

94 Large pups, cut, etc.

87 Large pups, cut, etc.

87

86

70 Middling pups, cut, ete.

70

99 Middling pups, cut, etc.

99

99

98

98

$\{87$ Small pups, cut, etc.

$\{9 \mathrm{Ex}$. small pups, cut, etc.

$\left\{\begin{array}{r}86 \\ 9\end{array}\right.$

115 Small pups, cut, etc.

115

115

115

60 Ex. small pups, cut, etc.

79 Faulty; 5 smalls, 16 large pups, 36 middling pups, 20 small pups, 2 ex. small pups.

One hundred skins, salted fur seal, Alaska.

Lot 245, 100 skins, 112/:

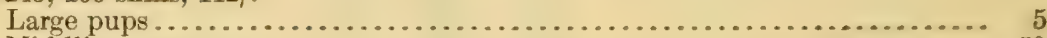

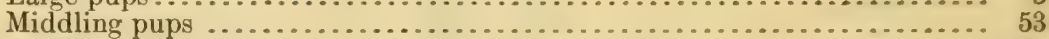

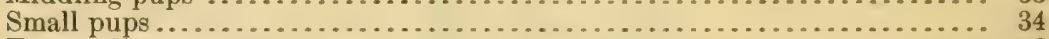

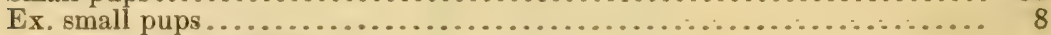

Recapitulation-1905 catch, Pribilof Islands, tally of catch as annotated.

9 to $10 \mathrm{lb}$. skins, middlings and smalls, "short" 4-year-olds, "long" 3-year-olds. .

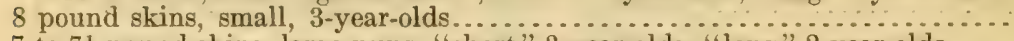

7 to $7 \frac{1}{2}$ pound skins, large pups, "short" 3 -year-olds, "long" 2 -year-olds.....

6 to $6 \frac{1}{2}$ pound skins, middling pups, 2 -year-olds, or "short" 2 -year-olds or

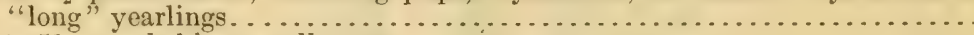

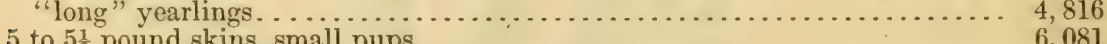

$4 \frac{1}{2}$ to 5 pound skins, extra small pups, "short" yearlings................... ${ }_{837}$

Total.............................................. 14,674

Yearlings................................................ 6,918

The above shows some 400 skins shipped in from 1904.

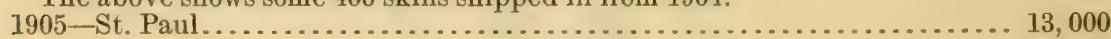

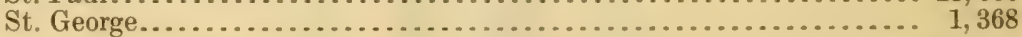

14,368

Note.-As to the "short 2-year-olds" of 1905 catch above cited, a "short" 2-year-old skin must be either from a well-grown yearling's body or from a small seal's body not of two years' growth, i. e., from a seal born late in July, 1904, and killed in June, 1905, or early in July, 1905, so putting it "under 2 years of age;" and so, contrary to the Hitcheock rules, it is taken. The benefit of the doubt which belongs to it is improperly denied.

This analysis shows that out of this season's eatch of 14,674 skins 6,918 of them were taken in violation of the Hitchcock rules. 


\section{EXHIBIT E.}

\section{[See recapitulation on p. 63.]}

C. M. Lampson \& Co. exposed for sale by auction at the College Hill Public Sale Room on Friday, December 14, 1906, at 10 o'clock, the following goods, viz, 14,392 skins, salted fur seal, Alaska; 86 skins, salted fur seal, Alaska. (Promjt, December 28, 1906.) The purchasers are particularly requested to have some one in attendance to superintend the counting, as no claim for deficiencies can be allowed after the goods have been counted and delivered from the warehouse.

\section{CONDITIONS OF SALE.}

First. The highest bidder to be the purchaser.

Second. The purchasers shall have an allowance of $£ 210$ s. per cent for discount and shall pay $2 \mathrm{~s}$. 6d. for each lot, together with a brokerage of one-half per cent to the selling brokers and a deposit of 25 per cent on the amount of their purchase, if required to do so, at the time of purchase.

The deposit must in any case be paid in full on or before the prompt day, and in case of default C. M. Lampson \& Co. are to be at liberty to resell any such lot or lots without further notice, and the buyer is to make good to them the deficiency (if any) of such resale, together with all expenses, in addition to forfeiting any part of the deposit which may have been paid, and should the goods sell for more on such resale than at the present sale the surplus shall belong to C. M. Lampson \& Co.

Third. From the day of sale, interest at the rate of 5 per cent per annum will be allowed on all payments made in anticipation of the prompt.

Fourth. All payments (except the charge for cold storage) to be made to the selling brokers, who will give orders for the delivery of the goods so paid for.

Fifth. The goods to be taken with all faults and to be paid for on or before the prompt day, but should any of the purchasers wish to delay clearing any of their goods they shall have the option of doing so on the following terms:

The amount of the purchase shall be ascertained and a deposit of not less than 25 per cent thereon paid to the selling brokers on or before the prompt day.

Interest at the rate of 5 per cent per annum will be charged on the amount unpaid from the prompt day to the day of payment.

Payment shall be made in full, with interest, nine months from the day of sale, say the 14th day of September, 1907, when the goods shall be cleared and taken away.

C. M. Lampson \& C 'o. are to be at liberty, as soon as they may think proper, to resell, without further notice, any goods which have not been cleared by the buyer on or before the 14th day of September, 1907, and the said buyer is to make good to them the deficiency (if any) of such resale, together with all expenses, in addition to forfeiting the deposit of 25 per cent, and should the goods sell for more on such resale than at the present sale the surplus shall belong to C. MI. Lampson \& Co.

Sixth. The selling brokers will not recoguize or act upon any notice from a purchaser of the transfer of any goods (purchased by him) to another party, unless they are satisfied as to the responsibility of such other party, and then only on the understanding that such other party accepts the goods subject to the sale conditions.

Seventh. That such of the purchasers as shall leave their goods in C. M. Lampson \& Co. 's warehouse (whether wholly or partially paid for) after the prompt day shall pay them on delivery of the goods for cold storage 1s. 6 d. per $£ 100$ on the amount of purchase for each week or part of a week from the prompt day until the goods are taken away from the cold store.

Fighth. That C. M. Lampson \& Co., being partners in the firm of C. W. Martin \& Sons, agree to consider any goods placed in the hands of that firm fur manufacturing purposes as being still in their own custody, on condition, however, that the skins shall not be drawn away from the cold store to the Alaska factory until Messrs. C. WV. Martin \& Sons are ready to commence manufacturing them.

Ninth. All goods, whether paid for or not. shall be at the risk of the purchasers from the day of sale, but they will be insured against fire. free of charge, until delivered under the conditions of C. MI. Lampson \& Co.'s policies with fire insurance companies.

Tenth. Should any dispute arise respecting the sale of any lot, the same shall be put up again and resold, and should any difference arise between any two or more buyers the same shall be left to the decision of the selling broker. 
Elerenth. Xo chams for dreferencies will be allowed by ('. M. Lamusun of ('o. atter the goods have been delivered from their warehotwe, nor do the sellers hold themselves responsible for the descriptions in this catalogue.

The selling brokers will deliver to the huyers on the morning following the sale a contract for the goods purchased, and the selling brokers will consider surhe contracts as accepted by the buyers, unless exception is taken to them within 24 hours of delivery of same.

In cold storage at Southeastern Wharf (samples at 6.4 (Qucen Street, E. C.), 14,992 stins, salted fur seal, Alaska.

[At per skin, to advance 1s.]

[Bujers are requested to note that all skins are stamped $\mathrm{L} \mathbf{A}$ on the right cheek.]

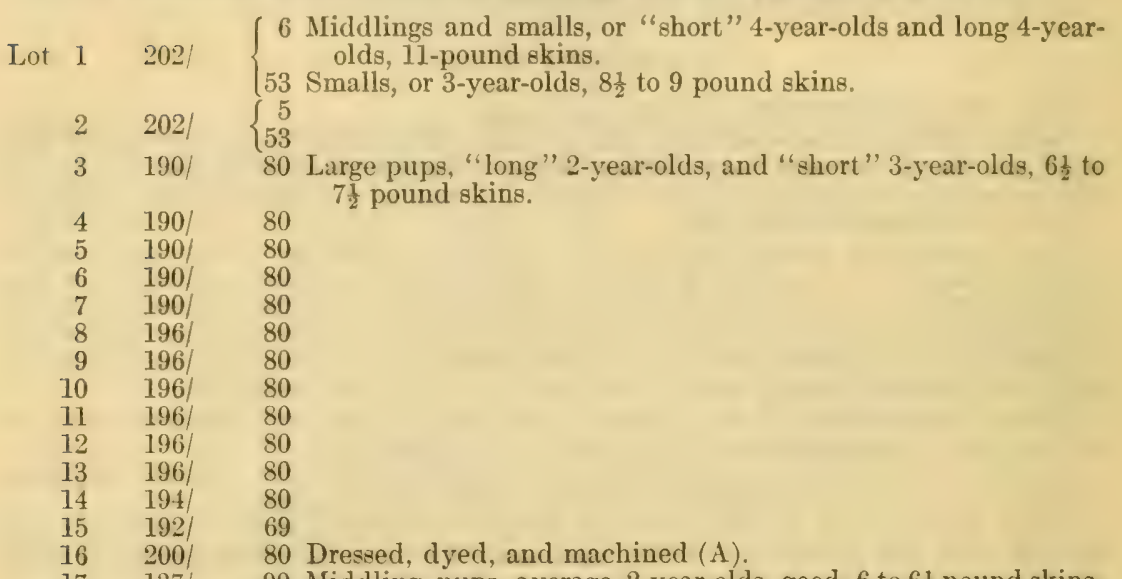

137| 90 Mirddling pups, average 2-year-olds, good, 6 to $6 \frac{1}{2}$ pound skins.

137/ 90

137/ 90

137) 90

137! 90

137) 90

137/ 90

137/ 90

137/ 90

136/ 90

136/ 90

$135 / 90$

135/ 90

135/ 90

135/ 90

135/ 90

135/ 90

135/ 90

135/ 90

135 \% 90

134/ 90

134/ 90

133/ 90

133/ 90

133/ 90

133/ 90

133/ 90

133/ 90

133/ 90

133/ 90

133/ 90

133/ 90

$49-1331 \quad 90$ 
In cold slorage at Southastern Wharf (samples at 6+ Qucen Street, E. r.), 14.392 stins, salted fur seal, Alaska-Continued.

Lot $50 \quad 133 / 90$ Middling pups, average 2 -year-olds, good, 6 to $6 \frac{1}{2}$ pound skins. $51133 / \quad 90$

$52 \quad 133 / \quad 90$

53 133/ 90

$54 \quad 133 / 90$

$55 \quad 133 / \quad 90$

$56 \quad 133 / \quad 90$

$\begin{array}{lll}57 & 133 / \quad 90\end{array}$

$\begin{array}{lll}58 & 133 / \quad 90\end{array}$

$59 \quad 133 / \quad 90$

$60 \quad 133 / \quad 90$

(i1 $133 / \quad 90$

$62 \quad 133 / \quad 90$

$63133 / 90$ Middling pups, 2-year-olds, 6 to $6 \frac{1}{2}$ pound skins.

$\begin{array}{lll}64 & 133 / & 90\end{array}$

$65 \quad 133 / \quad 90$

$66 \quad 133 / \quad 53$

$\begin{array}{lll}67 & 141 / & 90 / 413 \text { Dressed B. } \\ 68 & 112 / & 100 \text { Small pups, "short" 2-year-olds and "long" yearlings, } 5 \text { to } 5 \frac{1}{2}\end{array}$

$69 \quad 112 / 100$ pound skins.

$70 \quad 112 / \quad 100$

$\begin{array}{lll}71 & 112 / & 100\end{array}$

$\begin{array}{lll}72 & 112 / 100\end{array}$

$73112 / 100$

$74 \quad 112 / 100$

$\begin{array}{lll}75 & 112 / 100\end{array}$

$\begin{array}{lll}76 & 112 / 100\end{array}$

$\begin{array}{lll}77 & 112 / & 100\end{array}$

$\begin{array}{lll}78 & 113 / & 100\end{array}$

$\begin{array}{lll}79 & 112 / \quad 100\end{array}$

$80 \quad 112 / 100$

$\begin{array}{lll}81 & 112 / \quad 100\end{array}$

$82 \quad 112 / \quad 100$

$83112 / 100$

$84112 / \quad 100$

$85112 / 100$

$86113 / 100$

$87 \quad 112 / \quad 100$

$88 \quad 113 / \quad 100$

$\begin{array}{lll}89 & 113 / \quad 100\end{array}$

$90 \quad 113 / 100$

$11 \quad 113 / 100$

$92 \quad 113 / 100$

$93 \quad 113 / 100$

$94 \quad 113 / 100$

9.) $113 / 100$

$96 \quad 113 / 100$

$97 \quad 114 / \quad 100$

$98 \quad 114 / 100$

99 114/ 100

$100114 / 100$

$101 \quad 114 / 100$

102 114/ 100

$103114 / 100$

$104 \quad 114 / 100$

105 114/ 100

$106 \quad 114 / 100$

$107 \quad 114 / \quad 100$

108 114/ 100

109 114/ 100

110 114/ 100

111 114/ 100 
In cold storage at Southeastern Wharf (samples at 64 Queen Street, E. C.), 14,392 stins, salted fur seal, Alaska-Continued.

Lot 112 114/ 100 Small pups, "short" 2-year-olds and "long" yearlings, 5

$\begin{array}{llll}113 & 114 / & 100 & \text { to } 5 \frac{1}{2} \text { pound skins. } \\ 114 & 114 / & 100 \\ 115 & 114 / & 100 \\ 116 & 114 / & 100 \\ 117 & 114 / & 100 \\ 118 & 113 / & 100 \\ 119 & 113 / & 100 \\ 120 & 113 / & 100 \\ 121 & 113 / & 71 \\ 122 & 128 / & 100 \text { Dressed, dyed, and machined (C). }\end{array}$

123 101/ 110 Extra small pups, "short" yearlings, 4 to $4 \frac{1}{2}$ pound skins.

124 101/ 110

$125101 / 110$

$126 \quad 102 / \quad 110$

$127 \quad 102 / \quad 46$

128 108/ 44 Smalls, low, etc.

129 113/ 89 Large pups, etc.

$\begin{array}{lll}130 & 112 / & 89\end{array}$

$131 \quad 113 / \quad 89$

$132112 / 87$ middling pups, low, etc.

$\begin{array}{lll}133 & 112 / \quad 87\end{array}$

$134 \quad 112 / \quad 87$

$135113 / \quad 87$

$136 \quad 113 / \quad 87$

$137 \quad 113 / \quad 86$

$138 \quad 113 / \quad 86 ;$

$139 \quad 97 / \quad 116$ small pups, low, etc.

$140 \quad 99 / \quad 116$

$141 \quad 99 / \quad 115$

$142 \quad 88 / 28$ extra small pups, low, etc.

$143 \quad 182 / 50$ smalls, cut, etc.

$144166 / 71$ large pups, cut, etc.

$145166 / \quad 71$

$146 \quad 166 / \quad 72$

$147 \quad 125 / \quad 97$ middling pups, cut, etc.

$\begin{array}{lll}148 & 125 / \quad 97\end{array}$

$149125 / 97$

$150125 / \quad 97$

$151125 / 96$

$152125 / 96$

$153105 / 114$ small pups, cut, etc.

$154105 / 114$

$155 \quad 106 / 113$

$156105 / 113$

$157 \quad 95 / \quad 32$ extra small pups, cut, etc.

$15872 / 33$ faulty (12 large pups, 16 middling pups, 5 small pups).

86 skins, salted fur seal, Alaska.

Lot $159 \quad 92 / \quad 86$ skins ( 3 smalls, 12 large pups, 45 middling pups, 22 small pups; 2 extra small pups, 2 faulty).

London catch.

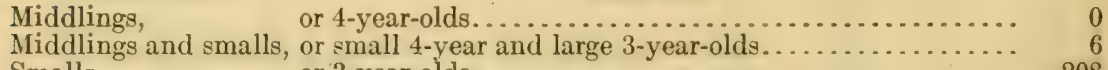

Island class.

Smalls,

Large pups,

Middling pups,

Small pups,

Extra small pups,

or 3 -year-olds.................................. 208

or small 3 -year-olds and large 2 -year-olds............. 1, 614 or average 2-year-olds or "long" and "short" 2-yearolds.................................. 5, 801 or 1-year-olds........................... 6, 289 or small 1 -year-olds (or "short") .................. ${ }_{548}$ 
Recapitulation, 1906 catch.

9-10-pound skins: Middlings and smalls ("smalls," 3-year-olds, large; "middlings," 4-year-olds, small)

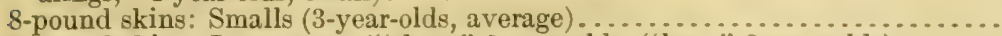
7-pound skins: Large pups ("short" 3 -year-olds, "long" 2-year-olds)........ 6-6 $\frac{1}{2}$-pound skins: Middling pups (2-year-olds, average, or "long" yearlings

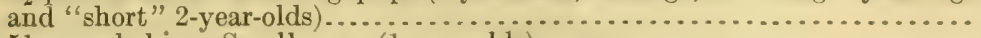

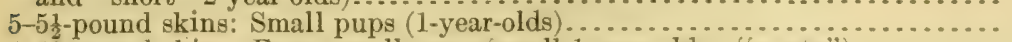

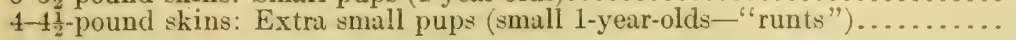

Yearlings

1906:

St. Paul.

10,942

St. George

Total by Secretary Metcalf's report, 1906, page 33, $14,643-12,627=2,016$; so these skins came over from the 1905 "food" skin deal.

This analysis and Secretary Metcalf's version of it on page 33 of his report for 1906 declares that the lessees took everything that herded out, save some 800 to 1,000 small yearlings, luring the season of 1906 . Nothing has been spared.

Note.-This analysis shows that out of this season's catch of 14,466 skins, 6,837 were taken in violation of the Hitchcock rules. 


\section{EXHIBIT F.}

Lee pp. til, ne of the Fur Trade lieview, New York, isue of Fet., 19t1; received at the Congressonal Library Feb. 7, 1911.]

Here is the official return made to the Secretary of commerce and Labor December 17, 1910, of the sale of 12,920 fur-seal skins taken on the Pribilof Islands during June and July, 1910, out of which 8,000 skins are the skins of yearling fur seals, all deliberately and knowingly taken in gross violation of the IIitcheock rules of May 1, 1904, and all of which skins are again falsely certified to the department as legally taken and "not under 2 years of age"; this done by United States Fish ('ommissioner Bowers and his subordinate agents on the seal islands of Alaska.

[Memorandum.]

FLAYS UNITED STATES SEAL POLICY-ZOOLOGIST TELLS SENATE COMMTTEE METHODS IN VOGUE PRODUCE ONLY WEAKLINGS.

Washington, February 4, 1910).-An attack upon the Government's policy in caring for fur seals upon the Pribilof Islands in Alaska was made to-day by Dr. William $T$. Hornaday, of the New York Zoological Gardens, and Prof. II. IW. Elliott. They spoke for the ('ampfire Club of America before the Senate C'ommittee on Conservation of National Resources.

The speakers declared that under the act of last year, which canceled the lease theretofore held by the North American Commercial Co. and gave control of the killing of fur seals to the Secretary of Commerce and Labor, there had been no cessation of wanton killing.

Dr. Hornaday condemned the policy of weeding out the males when they are babies, leaving only such number as was needed for breeding purposes. He declared that the system left weaklings. (Cleveland (Ohio) Plain Dealer, Feb. 5, 1911.)

[A memorandum for Senator Heylurn in re illegal and injurious killing of fur seals on the Pribilof Islands, and falsely certified to the Government as proper and legal hy its own sworn agents thereon.]

Saturday, February 4, before the Committee on Conservation of National Resources, Secretary Nagel appeared, and his agent in charge of the seal islands, W. I. Lembkey, made a statement to justify the killing of seals on those islands, as ordered by the Secretary last season and prior to that.

Mr. Lembkey's statement, stripped of verbiage, was in effect that-

I. He killed no seals under 2 years of age.

II. He killed no females.

III. He saved 5 per cent of the male 2 and 3 year olds; killed 95 per cent.

Each and every one of those statements is absolutely untrue, for-

I. IIe did kill more than 10,000 seals (out of the 12,920 which he took) which were under 2 years of age, and the London records of the sale, December 16 last, if produced, will declare it.

II. He did kill females, therefore, since at least one-third, if not quite one-half of the 10,000 "long yearlings" and "short 2-year-olds," which he killed last season, were females - since the yearlings haul out in equal numbers, males and females together, and are absolutely alike to all outward form, size, and color. (Lembkey admitted that. Ile also admitted that he could not tell the skins apart when removed from the bodies as to sex. He also admitted that there was no penalty ever inflicted for killing female seals.)

Mr. Lembkey was confronted with the proof that he did not even spare the 5 per cent "saved" 2 and 3 year old male seals, hut so managed this job that after "sparing" them in June and July he killed them in October and Novenber following, for "the natives' food!" He did not attempt to deny this proof; he could not; it was officially made.

Henry W. Elliott. 
THE ILLEGAL AND INJURIOUS KILLING OF FUR SEALS ON THE SEAL ISLANDS OF ALASKA. $1900-1910$.

[A memorandum of fact concerning the same for Senator Heyburn from HI. W. Elliott, Feb. 7, 1911.]

January, 1911, sales (ape IIom "salted" fur seals, only 3.50 skins; South Sea, only 22 skins; total, 372 skins. Sold for $£ 83,2272$ s. 3 d.

London, December 16, 1910, 12,920 Pribilof catch of 1910.

Analysis of the eatch on seal islands season of 1910, sold in London December 16, 1910:

Pound skins.

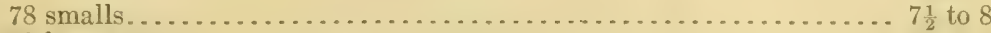

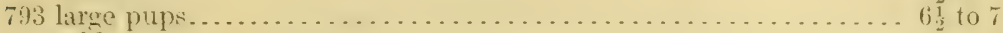

3,775 mid. pups........................................ $5 \frac{1}{2}$ to 6

6,195 small pups........................................... $4 \frac{1}{2}$ to 5

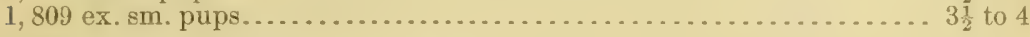

12,650 , or 8,004 under 2 years of age.

270 not well classified.

\section{2,920}

Average price, $\$ 34.38$ per skin; $£ \$ 3,2272$ s. $3 \mathrm{~d}$.

Smalls $(2,405)$ are 3 -year-old males.

Large pups $(2,18.5)$ are short 3 -year-cild males and long $(2,190) 2$-year-(1) males.

Middling pups (1, (6t5) äe short 2-vear-s)ld males and long yearlings males.

Small pups $(1,265)$ are yearling males and females.

Ex. sm. pups $(1,225)$ áre runty yearling males and females.

(Fur Trade Review, New York, Feb. 1, 1911, pp.61, 62.)

\section{Еввітт House,}

Thashington, D. C., February \%, 1911.

Hon. IT. B. HeYburN,

United States Senate.

MY DEAR SHe: I inclose, for your information and use, a memorandum based upon the oflicial returns from the sale of that killing made last summer on the seal islands by Secretary Nagel's direction.

That thit killing wat in violation of the statement male to your committee on ('onservation last saturday hy Mr. Nagel's agent is self-confesed by those indisputable figures of this London classification.

This is a seritus matter for Mr. Nigel. He has been wamed repeatedly that his agents were violating the law and rexulations of May 1, 1904; he has ignored these waming*; sn did Secretaries Shaw, Cortelyou, and fage ignore the warning; given them in regular order as to sngar weight fraluds. The men who warned these high officials were called "bores," "cranks," and "tiresome fellorss," etc., but at last they prevailed, and the fratuis were ended. This false entry of sealsibias taken in ojen flegrant vinlation of law will end when IIr. Nagel faces the same before the Judiriary ('mmittee of the sixty-second ('ongress. He will be obliged to admit his error in not hewing close to the line.

The official table of sealskin weights as the seal grows up from birth is published by the Government in Bulletin 176, Inited States Fish Commision, Washington, J. ('., 1852. No man has even hinter that its ficures were not correct until an erroneous table was put out by thic man Lembkey, in 1906-1908, in which he makes the yearling skins take the place of the pup skins 5 months old and just before they leave the islands for their first rea journey and life. These "gray pups" are seldom taken to the Iondon sales but when givoted run as follows ip) to the old bulls, or "wigs." The London terms and equivalents are-

Gray pups, or 5 months old

Pound skins.

Ex ex small pups, or 8 months old.............................. $3 \frac{1}{2}$

Ex small pups, or 10 months old............................... 4

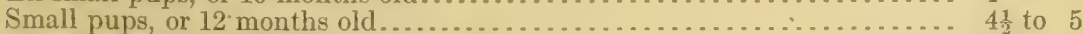

Middling pups, or 18 to 24 months old......................... $5 \frac{1}{2}$ to 6

Large pups, or 24 to 36 months old ....................................... 6 to 7

Smalls, or 36 to 40 months old.......................................... $7 \frac{1}{2}$ to 8

Middlings and smalls, or 40 to 48 months old................... $8 \frac{1}{2}$ to 10

Middlings, or 4 -year-olds................................. $10 \frac{1}{2}$ to 12

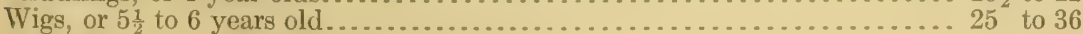

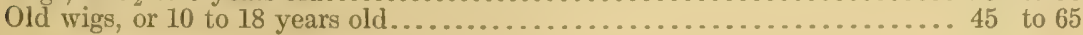

$95100-$ No. $1-11-5$ 
This slatement as above, of the London rlassifieation, and its interpretation to the age of the seal irom birth up to old age, was carefully studied out in $1872-1876$ on the seal istands by four l'nited states agents, seven agente of the lessees, and myself, and agreed upon then as the guide to all oflicial record of the work done on the islands. It is absolutely correct to-day; and it has been the standard used in all selection of skins since then by the lessees until very lately, when nothing has been left alive up there that could be lawfully killed.

Very truly, yours,

IfEnry W. Elliott, Care of Smithsonian Institution.

[Statement for Hon. W. B. Heyburn, Inited states Senator, regarding the illegal killing of seals on the seal islands of Alaska.]

Saturday, February 4, 1911, IV. I. Lembkey, agent of (harles Nagel, Secretary of commere and Labur, declared fo Senate (ommitfee on conservation of Tiatural Resoures, that he had killed 12,920 fur seals for their skins on the Pribiloi Islands durirg June and July, 1910. He denied the fact that he had killed ang seals "under 2 years of age" and in violation of that pledge given by the department March 10 , 1904, that it would not permit any killing under that age henceforth.

Tuesday, February 7, 1911. On pages 61 - f5: of the New York Fur Trade Review, February 1, 1911, and just received at the ('ongressional Library to-day, is the folIowing official claswifeation of the sale made Derember 16 last of those shins above cited in London, viz:

78 smalls, or 3 -year-olds

Pound skins.

793 large pups, or short 3 -year-olds or long 2 -year-olds.............. $6 \frac{1}{2}$ to 7

3,775 middling pups, or short 2 -year-olds and long yearlings $\ldots \ldots \ldots \ldots \ldots \ldots 5 \frac{1}{2}$ to 6

6,195 small pups, or yearlings....................................... 4 to 5

1,809 extra small pups, or "runty" yearlings...................... $3 \frac{1}{2}$ to 4

270 not well classified.

12,920 total, ont of which 8,000 skins are indisputably classified December 16 last as "under 2 years of age" and taken in violation of the rules of the department.

Henry IV. Elliott. 


\section{EXHIBIT G.}

17 Grace Avenue, Lakewood, Ohio,

December 19, 1906.

\section{Hon. Oscar Straus,}

Secretary Department Commerce and Labor, Washington, D. C.

DEAR SIR: In the report of the Secretary of commerce and Labor recently transmitted by the President to Congress, a discussion of the condition of the fur-seal herd of Alaska appears, and reference is made to the report of E. IV. Sims, who made an investigation into the status of this herd last summer.

The Secretary repeats the words of Mr. Sims, and says that the fur-seal herd is mapidly disappearing as the result of pelagie sealing; he also adds that in his judgment the "destructive eflect of this method of taking seals has not been fully realized"i. e., by any one until this season).

The secretary is right in saying that this herd is "mpidly disappearing," but is entirely wrong in saying that the destructive effert of pelagie sealing has not been fully realized; he does not seem to know that on the strength of my thowing of the full effect of pelagic sealing under existing law and regulations which I gave to the Ways and Means (Committee of the Hemse, December $21,18 \%$, that that committee and the Ionse tonk action February 2.2, 1895, to suppress and put the pelagic humer out of bu-iness; but this wise, sensible, and mer.iful action of the Honse was defeated in the senate by sworn agents of the foremnent, who denied this danger and injury incident to pelatgic sealing, raiming that the rules of the liering sea tribunal were suflicient to avert it.

Again I brought this danger of pelagir sealing forward in 1898, after the JordanThompen agreement of November 16 , 1s!3, had utterly denied it. Again my charges of this real danger were ofilially denied by sworn agents of the United states Government in the service of the Treasury Department and indored by the fecretary of that department in a letter dated February 7 , 1902, addressed to the chairman of the Ways and Means Committee of the House.

I answered this erroneons official statement of Secretary Shat by making an exhibit for the committee whirh clectared that by the end of the season of 1907 the male breeding life on the Pribind Istands would be extinet. (See Rept. Ways and Means Com., 2303; 57th Cong., 1st sess., pp. 4, 5.)

The eommitee overruled the cecretary of the Treasury and agreed with me; it reperted and pased a House bill, February 2, 1903, which would have put an end to the inhuman and indecent husiness of the pelagic hunter had it not been again defeated in the sonate by a false statement made to the Senate Foreign Relations ('ommittee * by senator Fairbanks, February 17, 1903, who assured his colleagues that an agreement to a satisfactory settlement had been reached in the Anglo-American Joint II igh Commission, and that that commission would publish it soon after it reconvened; that that reconvention would take place sonn after the th of March, 1903, henee, the House bill was not necessary.

I knew that this statement of Senator Fairbanks was without warrant and said so to his colleagues in the senate the time, hut the sine die arljormment on March 4 prevented action, and so this second attempt to suppress the pelagie hunter failed. And it haled not fom any want of molerstanding of the destructive effert of pelagic sealing, as the sercetary of cummere end labur says existed until the sims report of 1906 had been made. Mr. Metcali was himseli a member of the Ways and Means Committe in 1902 , when I gave that body the full understanding of this work of pelaric sealing, and he was also a member when I again reinforced my argument of 1902 with figures and facts, Narch 9-10, 1904.

Ile also heard my indictment of the excessive land killing by the lessees bedore this commitee in 1904 ; he heard it deried by the lessees, and only partly agreed to by the Iheiartment of (ommerce and labur, solely on the strength of my showing March (2-10). 1904, dicl the department pledge to the committee the amnual reservation of 2,000 choice voung male seals irom slatughier by the lessees on the Pribilof Islands.

(In the 261 in of (ictober, 1905, the agent of the department in charge of the seal islands of Alaska, in an official report admits that my rharge of injury through excessive land killing by the lessees is correct. (See p. Si, S. Doc. No. 98, 59th Cong., 1st sess.) 


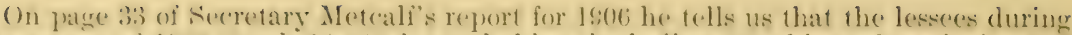

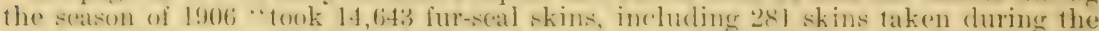
previons season." 'Then, in this same paragraph, and infuediately following, he says

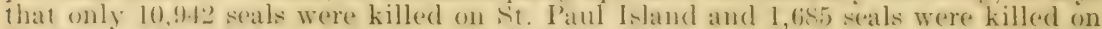
sit. Cieore Istand during the season of lsol;. 'This analysis which he makes of his own fienres derlares the fact that 2,016 skins, and not "issl skins," ('anse over into the catch of 1906 from 1905.

The sienifieance of this you will at ence ohserere when you understand that these.2,016

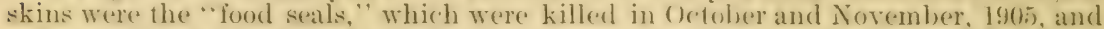
still more, they were the 2,00(0) choice young male seals ordered spared and sheared (not hranded) in Jume and rarly July, ls0), this sheared mark having entirely disappeared by the middle or end of sejutember, since every fir seal by the end of sep)tember anumally completely renews its own hair-sheds and grows it anew in August and September.

That this is not even faintly nuderstood by the sereretary is plain, for in the next paragraph he proceeds to tell" us that "in addition to the branded seals reserved for breeding purposes, 4,724 small and 1,944 large seals were dismissed from the drives as being ineligible for killing under the department's regulations."

Iore misinfomation with regard to the subject can not be put into fewer words. Witness the following:

I. These seals were not branded; they were shrared instead, in June and early July. Then by the end of September they completely lose this mark of reservation, and each and every one of them that hauls out on the Pribilof Islands during ()etoler"November is killed as a "food" seal, and the lessees get the skins, which are carried over into the catch for the next season. (See the official proof of this on 1). $8,64,65$, and 86 of S. Doc. No. 98, 59th Cong., 1st sess.)

II. These "4,774 small" scals do not represent in fact more than 800 or 1,000 such seals. Most of these seals have been recounted over and over again as they were redriven and then dismissed during the season. Some of them have reappeared in this fictitious total six or seven times.

III. These "1,944 large seals" were the sheared and spared seals of 1906 so marked in Jume and early July. Last October and November they were killed as they hauled out, as "food" scals, and their skins will appear in the quota or catch of the lexsees for" 1907 , if these men are permitted to kill next scason.

With regard to the report of Mr. Sims, I shall not dwell upon the many obvious and plain errors of statement and conclusion which ajpear in it. I do not do so because he admits that his experience in the premises is limited to a short week on the Seal Islands during the summer of 1906. No man, it matters not how great his inherent ability, can master this question and intelligently discuss it with so little experience.

With the single exception of correctly speaking of this immediate danger of complete extinction of the fur-seal herd of Alaska, under existing conditions, Mr. Sims is completely at sea and in profound error over everything that he brings into conclusion and recommends in his report of August 31, 1906.

Very sincerely, your friend and servant,

Henry IV. Elliott.

Department of Commerce and Labor, OfFice of the Secretary, Washington, January 2, $190 \%$.

Mr. H. W. Elisotт,

No. 17 Grace Avenue, Lakewood, Ohio.

Sir: I have to acknowledge the receipt of your letter of the 19 th ultimo, commenting upon that portion of the Secretary's last annual report which refers to the Alaskan fur-seal service, and to thank you for the information therein contained. Respectfully,

LaWRENCE O. MURRAY, Assistant Secretary.

No. 17 Grace Avenue, Lakewood, Ohio, May $18,1908$.

Hon. Oscar Straus,

Sccretary Commerce and Labor, Washington, D.C.

DEAR Sin: On the 19th of December, 1906, I addressed to you a letter in which I pointed ont to you certain pronounced errors of statement made in an official report to you by one E. W. Sims on the condition of the fur-seal herd of Alaska. That I did 
so was fairly imperative on my part, since these errors of statement and recommendation, which this inexperienced and wholly untrained aqent made, were entirely subversive of the truth, and most injurious for those public interests at stake, if acted favorably upon by you.

On the 2d of Jauuary, 1907, I received an official acknowledgment of the receipt of that letter aforesaid, with the simple "thank you for the information contained." That acknowledgment was enough; it made no suggestion of an error in any statement on my part. There was none, and I knew it when I addressed you.

My chief protest in that letter was against the grave mistatement by Mr. Sims, who said that all of those seals ordered spared by the Hitchcock rules were rluly "branded," and so exempted from slaughter ever afterward: by the lescee; that this "branding" was faithfully done, and those spared seals thus permitted to live, grow up into breeding bulli for the rookeries; all this officially and explicitly reported to you, when in fact, it was not true.

Therefore I described to you the manner in which these seals were not branded-not one of them-and how they were sheared instead. How this sheared mark was entirely lost a few weeks later when this seal went into its natural annual molt and renewed ail of its body hair. So that these sheared seals thus "branded" in Jume and July and spared then, when they hauled out again in October and November following were without any mark of exemption and were killed then by the lessees as "food " seals; that in this manner those land butehers were actually mullifying the regulations of the department, which MIr. Sims erroneously declared the faithful observance of to yol1.

What has been the result of this truthful and clear statement on my part to you made December 19,1906 ? What has been done with regard to the conduct of affiairs on the islands during the season following?

I have the official answer of the agents-your agents-now in my hands. It is printed as Senate Document. No. 376, Sixtieth Congress, first session. Since I have myseli officially reported to $\mathrm{my}$ Government on this life, and as I have so reported uj) to date that no man or official following me or prior to my work has thus far been able to successfully imnerch the entire truth and sense of $\mathrm{ny}$ published official records in 1881 and in 1890 (Monograph Seal Islands of Alaska, Government Printing Office, 1851), and (House Document No. 175, Fifty-fourth ('ongress, second sescion), I am constrained to review these reports of your agents for the seasons of 1906-7, inclusive. That review is herewith inclosed for your information and use. If I have made an error in it and it is publicly presented to me, I will be most happy to acknowledge it; but I desire to say that I do not believe it can be questioned seriously by any authority. I challenge the correction confidently.

Your agent, Mr. Lembkey, has no warrant or even the shadow of authority to ignore or dispute that table of skin weights which I officially published on page S1, IIonograph Seal Islands of Alaska in 1881. He can not and will not be permitted to set aside in this idle manner, as he does on page 84, Senate Document. No. 376, that long-estahlished and standard agreement of all the United States Treasury agents, the arents of the lessees, and myself, upon these skin weights, from 1872 up to 1881; and, still more, his attempt to deny that record so officially published is in turn flatly denied by the life and growth of the fur seal itself to-day. That life and growth has not changed one hair'sbreadth from its order when I, first of all men, accurately recorded it in my published work-officially recorded it in 1872-90 inclusive.

I desire to say that it is with great reluctance that I take up this matter; but I can not let any officialism of to-day reflect ever so little upon my own of yesterdav and which I shall defend against all ignorant or venal criticism, now and in the future, just as sucressfully as I have done so in the past. I refer especially to the "scientific" vagaries of Merriam and Jordan in 1891 and $1896-7$ and the venal and calumnious work of John W. Foster before the Bering Sea Tribunal in 1893.

In the light of this letter, herewith inclosed, and which can not be truthfully clouded by any man, it must he clear to you that the lessees can not be permitted by you to safely kill a seal next summer on the Pribiln Islands; but your agents can be directed to permit the natives to kill some 2,500 or 3,000 small male seals for fond without any risk to mention of doing injury to the public interests concerned.

I am, very respectfully, your most obedient servant,

Henry W. Elliott.

On page 84, Senate Document No. 376, Sixtieth Congress, first session, Lembkey publishes a table of skin weights under date of December 1, 1907. The positive errors of this tabulation are as follows:

Elliott, 1881: 45 to 60 pound green skins are 7-year-olds and upward. Elliott, 1881: 25 to 30 pound green skins are 6-year-olds. Elliott, 1881: 16 to 20 pound green skins 
are 5-year-olds. Elliott, 18S1: 11 to 14 pound green skins are 4-year-olds (are not 6-year-olds.-Lembkey). Elliott, 1881: 7 to 9 pound green skins are 3-year-olds (are not 4 or 5 year olds.-Lembkey). Elliott, 1881: 51 to $6 \frac{1}{2}$ pound green skins are 2-yearolds (are not 3-year-olds.-Lembkey). Elliott, 1881: 1 to 5 pound green skins are 1-year-olds (are not 2-year-olds.-Lembkey). Ellintt, 18S1: 3 to $3 \frac{1}{2}$ pound green skins are 5 months old (are not 1-year-olds:-Lembkey).

The Elliott table above cited was prepared in $1872-1876$ by United States Treasury agents, Bryant, Lessen, Falconer, and Elliott, with the following agreement in it by lessee argents, H. W. and H. II. McIntyre, Daniel Webster, T. F. Iforgan, Dr. Kramer, $\Pi \mathrm{m}$. Kapus and Geo. R. Adams, and is officially published on page 81 . (Monograph Seal Islands of Alaska, 1882. Tenth Census, United States America, Government Printing Office.)

[From the Cleveland Plain Dealer May 17, 1908.]

DECLARES SEAL REPORTS UNTRUE-PROF. ELLIOTT POINTS OUT INACCURACIES IN IN STATEMENTS ON PELAGIC INDUSTRY-SCORES OFFICIALISM WHICH PERMITS CONDITIONS NOW EXISTING.

Prof. H. W. Elliott, of Lakewood, who is an authority on the pelagic industry, made the following statement yesterday in regard to certain phases of recent reports on the conditions of the fur seal herd and the sealing industry. Prof. Elliott says:

"Editor Platn Dealer.

"Sir: On the 28th of last January you published a letter from me on the "loot and ruin of the fur seal herd of Alaska." In that letter I called attention to the fact that the official report of its custodian (Secretary of Commerce and Labor) did not give a hint to the President or to Congress of the total collapse of the legitimate business of killing fur seals by the lessees, which took place on the seal islands of Alaska last summer. I mentioned the fact that this had taken place, and yet it had been concealed from the public by its official keepers.

"I now write to say that the United States Senate on March 2, last, directed that the Secretary of (ommerce and Labor send to it copies of all reports of the agents of the Government who are stationed on the seal islands for the seasons of 1906-7, inclusive; that request has been complied with, and I have a printed copy of them now in my hands, as Senate Document, No. 376, Sixtieth Congress, first session.

'I find in this document the full and complete proof of the statements made to you in my letter of January last (cited above); so complete and so indisputable is this proof that I desired to submit a brief résumé of it for the readers of the Plain Dealer.

"In the first place, as to the whole number of fur seals surviving when this report of the agent in charge was made, at the close of the season, August 1, 1907, the following remarkable statements are made by him:

" On page 9 (S. Doc. No. 376) Chief Special Agent Lembkey says that after a careful count and estimate had been made by him and his three official assistants, there were not more than 185,000 seals of all classes alive on the Pribilof rookeries, August 1, 1906.",

After giving us this census he proceeds to describe the destructive work of the pelagic sealing fleet, which began its operations immediately after August 1, 1906, around the seal islands in Bering Sea. He describes the slaughter of this fleet at length on pages 30-31 and sums it up finally under date of 1906 as follows:

"In view of the facts just mentioned it may fairly be believed that the catch of 27,216 skins by the pelagic fleet in 1906 represents a loss to the herd of upward of 75,000 animals."

Here were we officially told that this herd of 185,000 seals has sustained a loss (since August 1, 1906, up to December 14, 1906) of upward of 75,000 animals; thus he informs us that it can not number more than 110,000 seals at the opening of the season of 1907 ; there is no ambiguity in this statement by him.

But this same agent, with strange disregard for his own words and figures, as above quoted, in his official report for 1907 , dated December 1 last, declares on page 87 that

"172,512" seals of all classes are in existence on the Pribilof rookeries August 1, 1907.

Does this agent understand the meaning of words and the significance of figures? If so, how does he subtract 75,000 seals from 185,000 seals in 1906 so as to leave the sum total of 172,512 seals alive August 1,1907 ?

The self-evident nonsense of this enumeration-its self-evident untruth-is too apparent for further comment.

In the Ways and Means Committee, House of Representatives, at a hearing held on this subject January 14, 1907, I specifically charged these lessees with the violation 
of their obligation to the Gorernment: I charged them with the nullification of the "Hitchcock rules" on the islands: I charged them with killing in Octol)er and November those seals which were spared and ordered exempt from their lilling in June and July preceding: I gave the committee the complete details of that illegal killing (for certain reasons the chairman of that committee has not made that testimony public up to date - why?), and now I find this official admissiom on page 13 (S. Doc. No. 376), by ('hief Special Agent Lembkey, that I was right then, but that now (December 14, 190()$_{1}$ "measures have been taken by the agents to avoid including in the fall killings for food the bachelors reserved in the spring as breeders. ****

"Furthermore. the 3-year-olds, having passed the age of puberty, are not found on the hauling grounds during the fall, but are hauled among the cows on the rookeries when they can not be driven. This is an additional safeguard against their killing, and of itself would disprove any allegation that these marked seals are subsequently killed."

How unfortunate it is for (hief Special Agent Lembkey to have on page 10:, following an emphatic and positive denial of the above quoted statement made to him by his own official assistant on St. George Island, dated June 3, 1907, to wit:

Seals. - Four hundred and fifty-eight seals of the quota of 500 allowed the natives of this island for food were obtained. The first drive was made on Oetober 19, from Staraya Artel, and 220 seals were killed; 209 small, sixty-five 3-year-olds, five 4 -year-olds, six 5-year-olds, two 6-year-olds, and 4 branded were turned away. Three other drives were made as follows: October 31, Staraya Artel rookery, 148 seals were killed, twelve 3-year-olds released; November 9, Staraya Artel and north, 44 seals killed; November 16, North rookery, 25 seals killed; October 20 to November 10 , Zapadni Guards, 21 seals killed.

The last three drives were made up entirely of seals pulled out from among the cows by the natives, and as very careful selection had taken place on the rookery very few were turned away from the killing field.

Of the 511 seals which composed the drive of October 19 only 4 bore any signs of having been branded, and these signs were extremely indistinct. No branded seals were seen after this date. It is quite evident that in the majority of cases the brands put on in June are by a rapid growth of new fur during the interval from August 1 to October 19 so entirely obliterated that they can not be depended upon to protect the seals during the food killings in the fall. To meet this condition I confined the killing as near as possible to those animals haring skins weighing from 5 to $6 \frac{1}{2}$ pounds, but despite the most careful and painstaking effort 45 skins weighing over $6 \frac{1}{2}$ pounds were taken. (For detailed statement of weights of skins see Exhibit B.)

This St. George official is telling the truth; his superior officer is not telling the truth-the whole truth to the Secretary of commerce and Labor; and this official evidence of that fact is now before the Senate and the American people. It bears me out to the letter. I know that this Sr. George agent is telling the truth. I myself saw this same "fulling out" of young male seals from the protection of the cows on $\mathrm{St}$. Paul Island in 1890 . It was done then and there, just as it is done now, by order of the lessees. I stopped it July 20, 1890, and it would be stopped to-day if the Government's agents did their duty. "Will it be, now that this public exposure of their illegal killing is made? We shall see.

The lessees have been killing fur seals on the Pribilof Islands in open violation of the law and their lease ever since 1895; they have so prevailed upon the Department of Commerce and Labor as to get that minimum $5 \frac{1}{2}$-pound skin allowed them by the "Hitcheock rules" of 1904 lowered in 1906 to 5 pounds. (See p. 14, S. Doc. 376.) Why?

Because it enables them to "load " "rery yearling's skin with blubber when skinning it off from the carcass, so as to "officially" weigh it in as a "5-pound skin," and have an entry (falsely) made against it as a "2-year-old skin."

This evidence of guilt is carried in the catalogues of those Iondon sales ever since 1894. Their catches of 1896 were the begiming of this improper killing to any extent. It became sa bad in 1900 that I then protested it to the Treasury Departnent. It was furtively denied. It caused me to bring this abuse to the attention of (ongress in 1904, and I did so with such abundant proof of my charge that the secretary of Commerce and Labor, on March 9-10, 1904, nrdered this check upon the work now known as the "Ilitehenck rules" of May 1, 1904. That these rules are being violated in turn is officially self-confessed, as above cited. (In S. Doc. 376, p. 105.)

I called attention in my letter to you last January to this fict, that the lessees did not dare to expose their catch of $190-7$ to Jublic sale (as advertised) in London Derember 17 last. They dirl not dare to expose the record of their work last summer to the telltale exhibit of a sales catalogue of the shins. Why? Recause it was made up of suçh a wholesale killing of small yearling "runt" and "eyeplaster" skins that even 


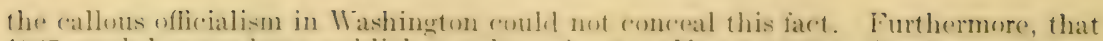

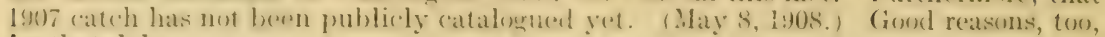
for that delay.

There is another feature about this killine wi rearlines on the islands: it is rlue to the fact that after the loth of July anmually the fomale vetarlings hatul out in even erreater numbers than do the males, and they all haul together; no man living can tell them apart as tosex unless he handles thim first. They are never handled first; they are always clubbed first.

These small skins (all taken in violation of the "Witcheork rules") last summer (5-pound skins), when exposed last Inecember in London, aroused the buyers to openly declare that the very dregs at last had been frawn upon and the end was certainly in sight; that comment was enough; this sale was then suddenly postponed of that Pribilof catch, herauge this talk and that catalogue of those skins would embarrass the butchers and their friends in Washington; it might prevent them from getting into the islands again in 1908 to skin up what was left, perhaps.

To shield this illegal killing of yearling seals by the lessees on the islands, the chief special agent in charge of that work had been unhappily led into publishing a table of skin weights, which is entirely erroneous.

That warrant has the author for this oftirial blunder, to say the least? Ile has none whatever. Those skin weights which he has attempted to classify improperly have all been determined and oflicially published in 1881. (see p). 81, Monograph Seal Islands of Alaska, Government Printing Office, 1881:)

That official tabulation of 1881 has never been questioned by any authority up to date; it can not be; it was the consensus of four white United States Treasury agents. six white agents of the lessees, and myself upon this subject during the seasons of 1572, 1873, 1874, and 1S76, upon the killing grounds of St. Paul and St. George Islands; we weighed thousands of skins and made no mistake in getting the right weights as to ages of those skins. 'This attempt to shield the real character of the improper killing by the lessees since 1895 by ofticialism of such error will not succeed.

17 Grace Avenue, Lakewood, OHio, May 9, 1908.

HENRY W. Elimoto

\section{Fourteenth Street, NW., Washington, D. C.,} December \%, 1908.

\section{Hon. Oscar Straus, \\ Secretary Commerce and Labor.}

DEAR SiR: On the 18th of May last I addressed a letter to you, in which I called your attention to the salient errors of statement made to you in the 1906-7 reports of your seal island agent, as printed by order of the Secretary. (S. Doc. No. 376, 60th Cong., 1st sess.)

In this letter aforesaid I inclosed a published review of that work of your agent. (Plain Dealer, Cleveland, Ohic, May 17, 1908.) I charged the lessees in this article (as inclosed) with the violation of their contract, since in taking their catch for 1907 they had killed yearling seals, and had done so because they were obliged to kill them or fail to get the 15,000 skins you allowed them to get under the terms of the Hitchcock rules. To get them they have openly violated those regulations of the department, and the inclosed evidence of their own sales agent in London convicts them of that chargeindisputably convicts them.

Even if we were to admit for sake of argument on this score that Special Agent Lembkey's classification of skin weights is correct, as published on page 84, Senate Document No. 376, above cited, even then this London classification declares that at least 6,000 yearlings were killed in the total catch of last season (1908). They must take these yearlings or have nothing-there is nothing left. That is the fact, and these men are draining the very dregs of that life up there to get the quota you allow them to have.

Very sincerely, yours,

HenRy W. ElliotT. 
[From the Evening Star, Washington, Friday, Dec. 4, 1908.]

[Inclosed in letter to Secretary Straus, Dee. 8, 1908.]

WHAT DELAYS THE SEAL SETTLEMENT?

\section{To the EDitor of The Star:}

The secretary of commeres and Labor in his amunal report. just submetted to the President, has the following significant references to the desperate comblition of onir Alaskan fur-seal herd. He says:

"Thirty-seven Japanese sealing vessels were reported as cruising around in the waters adjacent to the Seal Islands during the season. * * * Eight vessels only were sent out as the British Columbian fleet."

In other works, the Secretary tells this that some 45 huming schomers, carrying at least 1.500 hunters, eager, grecely, hardy seal hunters, have been busy all during the season just ended in shanghtering seals at sen around the bresding roukdites on the Pribiloi Islands. VIr. Stratis dues not tell us how many seals these seal catherers have taken, but he does tell us how few seals there were in existence up there when his agents made their reports to him, July 31, 1908. He says:

"From more than 1,000,000) breeding females estimated betore pelagic sealing became of "onsiderable extent this number has berome reduced to fewer than in), (000)."

Naturally Serretary Straus closes his report to the President, above cited. with the following self-evident proposition. to wit:

"It is evident that the time is at hand when the negotiations s.) long pending for an intermational arrangement for the settlement of the fitr-seal quest ion should be brought to a conclusion.'"

Certainly they should. But why are they held up? Who is to blame? The Canadian secretary of state. Rt. Hon. Mr. Scott, in an open session of the Dominion Senate, February 21, 1908, said:

"These sealers are now acting like a band of pirates. * * Canada is quite ready to enter into negutiations with the Linited States with a view to the adontion of mutually protective regulations. ${ }_{i}^{*} *$ She is ready to take it up whenever there is a proposition to do so from the United States. * * * There has been no such propusition nip to the present. * * * My remarks are inspired by the existing condition of the sealeries, which does not reflect favorably on the intelligence of the nations interested."

Few people stop to think of this fact-that in its present condition of complete ruin the fur-seal herd of Alaska represents a loss to us of more than $\$ 50,000,000 \mathrm{in}$ public property since 1890 . It is also a loss made still worse since it has been attended with the most shameiul and cruel license to butcher to that destruction this valuable and harmless wild animal life.

The Secretary says truly that the number of breeding females up to July 31, 1908, "has become reduced to less than 50,000 ." But he does not tell us how much more reduced since July 31, 1908, that number is; he does not tell us that this flect of 45 British and Japanese sealing whooners has been busy killing these female seals around the islands in Bering Sea ever since his report closed, as above cited, up to the end of this season in those waters, i. e., ()ctober 10-20 last. He does not tell us, becalise there is no authentic record of this pelagic eatch extant at this hour; it will not be known until the end of this month; but we can safely assume that this fleet will have taken at least 15,000 of those breeding females which were alive when this estimate of "fewer than 50,000 " was made by the agents of the department July 31 last. It is more likely that full 20,000 of that pitiful remant were taken by those hunters up to November 1 last.

Therefore it is an easy matter for one to figure out what a faint margin of fur-seal life is left on those islands to withstand the attack again upon it next season which this horde of greedy hunters intend to make, fully realizing as they do that it is their last chance to kill, since when they finish nothing will be left to kill.

What arouses me most in this connection is the fact that unless this fur-seal life now at stake is preserved from extermination on those islands of its birth it can not be preserved elsewhere. You can not take fur seals, as you can sea lions and hair seals, into captivity of any kind and keep them alive. Fou can not put them in zoological tanks and prevent them from dying of self-imposed starvation. The attempt to do so has been made over and over again, only to result in complete failure.

The fur seal born and bred in Bering Sea is the wildest of all wild animals, and unless we prevent its destruction on the Pribilof Islands we can not even preserve the species itself elsewhere. That is the reason why it is fairly wicked on our part if we do not now step in and stop) our own butchers of that life; if we do, then we have the official 
assurance of the (anadian ministry that they will submerge their butchers; otherwise, they will not. They are right; there is so difference in the rank and smell of those human wolves.

What delays the fur-seal settlement?

Henty W. Elliott.

This classification of the lessees' skins is given below in this order by the sales agent of the lessees, to wit-

[From Fur Trade Review.]

Dec. 1, 1908, New York (p. 908).

Probable offerings Dec. 17, 1908 (London sales).

Middlings and smalls, 4-year-olds.

Smalls (in lots of 70 skins), 3-year-olds.

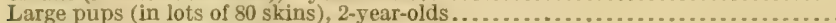

1-year-olds, long and short:

Middling pups (in lots of 90 skins).

Small pups (in lots of 100 skins).

Extra small pups (in lots of 110 skins), runts, 1 year old acom

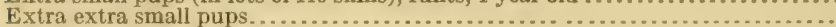

Middling and small, low, etc......................................................

Small, low, etc.

Iarge pups, low, etc:-

Middling pups, low, ete.

Small pups, low, etc

Extra small pups, low, etc.

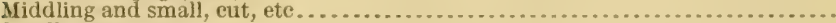

Small, cut, etc.

Large pups, cut, etc.

(1)

Mridding pups, cut, etc.

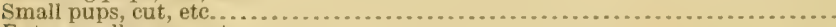

Exira small pups, eut.

Faulty pups.

Total. \begin{tabular}{|c|c}
$\begin{array}{c}\text { Total } 1908 \\
\text { catch. }\end{array}$ & $\begin{array}{c}\text { Remainder } \\
\text { of } 1907 \\
\text { catch. }\end{array}$
\end{tabular}

LAKEWOOD, Оніо, April 26, 1909.

Hon. Chas. R. NAgeL,

Secretary Commerce and Labor, Washington, D. C.

DeAr Sir: On the Sth of May, 1908, I addressed a letter to your immediate predecessor, inclosing a copy of a recent publication of facts over my own signature. In this letter I urged him to shut down that work of the lessees on the seal islands of Alaska, since it was being done in open and self-confessed violation of the regulations of the Government. The published statements, which I took the trouble to arrange and present in this responsible manner to him, demanded that action from him. But he took none. And still more, he did not even acknowledge the receipt of my letter aforesaid, which gave him this information, lacking on his part in the premises.

However, I know that such silence is the common refuge of that particular officialism which is both unable and unwilling to dispute a statement of fact rumning counter to its order. But I simply did my duty in the premises, as a good citizen should do.

Now, it is both my duty and my pleasure to renew this request and address it to you, and to inclose copies of the publications as sent to Mr. Straus last May, Also, in this connection, I desire to add that on I)ecember 7, 1908, I again submitted additional figures and facts to Mr. Straus, in a letter of that date, which declared that the lessees har again violated the specific terms of their contract during the season of 1908 by killing thousands of seals specifically prohibited from such killing by the express order of the Hitcheock rules. To this letter and its indisputable serious rharge no arknowledgment has been made; no attempt to deny its statements has been even hinted at. The reason for that silence is gond. The truth of my charge has been self-confessed by the lessees in London.

I therefore, on the strength of those figures and facts which I have submitted to the demartment, as above cited (May 18 and December 7,1908 ), respectfully renew my request that this work of the lessees be wholly suspended, and at once. I do so in the clear light of the inclosed statements of fact. I also recommend that the law which bonds and binds this corporation leasing the seal islands of Alaska be enforced 
before it shall be too late to reach the lessees with those fines and penalties ordered by it for the public good.

I am, very respectfully, your friend and servant,

Hentry IV. Elliots.

DepartMent OF COMMERCE AND JABBOR,

Bureau of Fisheries,

Washington, A pril 29, 1909.

\section{Mr. Henry W. Elliott,}

\section{Lakewood, Ohio.}

SIR: This bureau has received, by reference from the department, your letter of the 26th instant, in which you invite attention to the condition of the seal herd on the Pribilof Islands, and inclosed clippings on the same subject from the ('leveland Plain Dealer, together with your comments thereon. Your communication, with its inclosures, has been placed on file.

Very respectfully,

GEo. M. Bowers, Commissioner.

\section{Hon. Charles Nagen,}

LAKEWOOD, OHIO, June 25, 1909.

Secretary Commerce and Labor, Washington, D. C.

DEAR Sir: I want to put on record in the Department of Commerce and Labor this letter of respectful but firm protest. I do so because I have learned that in the face of the facts and figures which I have given to it in my letter of April 26, 1909, it has decided to send one George $A$. (lark as an expert up to the seal islands to make another report upon the condition of the fur-seal herd of Alaska.

This is the same (lark who united with Dr. D. I. Jordan in a letter to Senator Dillingham on January 30(?), 1904. In this letter he declared that there was no need of any interference with the order and rules established on the islands in so far as the killing by the lessees was concemed; that the lessees were doing no harm; that there was i great surplus of male seals on the islands, inacressible places, so hunted that the lessees could not reach to kill them even if they tried to.

This confession of his own unfitness to judge or advise the department in his own handwriting is in Senator Dillingham's possession, and appended to it is a review of its errors. Undoubtedly the Senator will give you a copy.

I had to combat this nonsense and injurious influence of Jordan and ("lark in the department during the winter of 1904 . Finally Mr. F. H. Hitchcock sided with me. The result was the ordering up of the "Hitchcock rules" May 1, 1904, over the protest of the lessees and their "scientific" allies, Jordan and clark. I therefore protest against any more of this "blind leading the blind" in so far as the public business on the seal islands of Alaska is concerned.

Very respectfully, yours,

HenRy W. Elliott.

Hon. Chas. Nagel,

LAKewood, OMIo, May 9, 1910.

Secretary Commerce and Labor.

DEAR SIR: The reason why a new and competent audit of the seal island books must be made in your department, and why it is demanded imperatively for the public good, is as follows, briefly stated:

I. The law has been openly violated on the killing grounds of the islands, and the terms of the lease ignored by the lessees thereof at frequent intervals, and repeatedly, from July 17,1890 , up) to the ('lose of the season of 1909 . This vinaltion of the law and the contract has been chiefly by the act of killing female and yearling male seals; said killings have not been in negligible numbers, but have run up into the tens of thousands of female and yearling male seals.

II. This illegal and improper killing has been ordered by the lessees, and falsely certified into vour department, as the taking of male seals according to law and the rules of your department.

III. The full and complete proof of this illegal killing as specified above exists on the islands and in the records of the sales of those skins. Any competent and honest auditor of those records will lay them open and so disclose the truth of those charges as made in Items I and II.

Very truly, yours, 
Hon. Chas. NageL,

LAKEWOOD, OHO, May 24, 1910.

Secretary Commerce and Labor, Washington, D.C.

I) En SIr As a good ritizen and being posesserl of abundant knowledere based upon indisputable fact, I addressed a letter dated December 18,1906 , to your immediate predecessur. IIon. ()scar Straus. In this letter to him I specified certain grave and inexcusable crors of official reports made to him by his subordinates and certain specific acts of official malfeasance by the same, in re conduct of the public business on the seal islands of Alaska.

On the $2 d$ of January, 1907, I received a single acknowledgment of the receipt of this letter, above citeil, with "thanks for the information contained;" but taking notice of the fact that in spite of the indisputable truth of my charges and propriety of prompt reform to be made by him in the premises, Mr. Straus had made no move to do su, again I addressed a cautious letter $M a y$ 1s, 1907, to him, in which I renewed those charges and recuest for reform. To this letter I have never received even that periunctory acknowledgment which was the entire return for my first one.

Of course I know why it was not answered-that subordinate officialism was guilty as indicted. It pigeonholed my letters; yet I had charity for Mr. Straus. I knew how hard it is for one in his position to get at the truth, so I quietly gathered an additional statement of fact bearing on this guilty officialism aforesaid, and again on December 7, 1903, I addressed a letter, courteously but firmly renewing my charges and request that he put an end to this malfeasance specified.

Did I receive an answer? No. Why? Because that guilty officialism again silently pigeonholed my letter, since it convicted and dismissed certain officers if acted upon.

Mr. Straus went out of office March 4, 1909. You succeeded. Knowing that you could not have any definite knowledge of this fur-seal business under your direction, except as you gathered it from this same guilty officialism aforesaid, I addressed you in turn a letter dated A pril 26,1909 , exposing that malfeasance under your hand. On the 29 th following your perfunctory acknowledgment of its receipt came to me.

But to this day no attempt has been made since by you to answer its grave, explicit, and indisputable charges of official malfeasance on the part of your subordinates. Of course there is good reason for this silence on the part of that officialism thus indicted. It is guilty. But yet what are you sworn to do in the premises?

On the 9 th instant I have addressed to you a final brief of this malfeasance on the part of your seal island subordinates. Will continued silence on your part vindicate them?

Very truly, yours,

HeNRy W. ELLIOTT. 


\section{EXHIBIT H.}

President informed December 9, 1906, of fraudulent killing by lessees on seal islands of Alaska-C'overed in the Sins report-Unmasking the Sims-Bowers deceit of their report sent to ('ongress by him in re condition of the herd-This has been suppressed by George M. Bowers and kept from the knowledge of Secretary Nagel-The guilt of Bowers; he was on the islands this July of 1906, just seven days, with Sims, then these "expert" ofticials left the islands, having "investigated," and "determined the truth" as to this fur-seal question; neither of them had ever been on the islands, and neither of them had ever seen a fur seal before, and neither of them had any training or knowledge as naturalists.

\section{Washincton, D. C., December 9, 1906.}

Dear Mr. Loeb: I am greatly pleased over the President's message with special regard for the preservation and protection of our fur-seal herd.

I saw the Sims report resterday for the first time, and I desire to quietly, yet pointedly, draw the attention of the President to al very remarkable and unwarranted error of statement macle in it by its author, to wit, oin page 28 Mr. Nims says that …, 000 choice 2 and 3 year old males were setected, branded, and dismissed from the herd for breeding purposes," i. e, saved then and thereafter from slanghter by the lessees. A gain, on pare 29, he says: "The experience of recent years in annually branding 2,000 young male seals," etc.

This deliberate statement of Mr. Sims is not true; these seals have not been "branded"-they have been "sheared"; these "sheared" marks have been put upon these seals in June and July, and they have entirely disappeared from these seals by the midrle or end of September following, since all fur seals completely shed and renew their over hair during August and September.

Please observe the simnificance of what follows. In ()ctober and November every one of these spared and sheared seals of June and July that hauls out on St. Paul and St. Geurge Islands is killed as a "food skin" seal, and its hide goes into the lessee's catch for the ensuing season.

The oficial proof of this serious charge you will find unwittingly furnished by the seal island agents themselves. On parges 8 , 64 , and 65 of Senate Document No. 98, Fifty-ninth Congress, first session, you will find it officially stated that the use of the branding irons was partly discontinued in 1904 and wholly discontinued in 1905 . On page 86 of this Senate document you will find the official declaration that these seals, "sheared" in June and July, are killed as "food seals" in October and Novemberthe "sheared" mark being entirely gone then. In this method of procedure, the President will observe that the lessees nullify the pledge given by the Department of Commerce and Labor to the Ways and Means Committee, the senatorial committee, and myself, March 9-10, 1904.

Mr. Sims has been imposed upon, perhaps; nevertheless, he does not understand the real status of this work done on the islands, and hence all of his labored conclusiong based upon this fictitious reservation of young male life, are utterly idle and unfounded.

When we have mercifully, humanely, and sensibly put the land and sea butchers of this fur-seal life out of business, by killing it down to the small nucleus sufficient alone to preserve the species, then we shall have no difficulty in getting a proper agreement with Camada for the full restoration and preservation of this fur-seal herd of Alaska. Faithfully, yours,

WM. LOEB, Jr.,

HENRY W. ElLIOTT. Secretary to the President, White House. 


\section{A Brief Review of tire Report of E. W. Sims on "The Alaskan Fur Seal Fisheries," Submitted to the President December 9, 1906.}

This report of E. IV. Sims is bas a upon no personal invest igation by him and study of this stattus of the fur-seal herd. 'The author tells us that he has had but one week's experience on the seal islands of Alaska, and that particular time was during July, 1906. Prior to that time and since then he had never seen a live fur seal, and has not seen one; he is not a naturalist and has never given it a serious thought.

II is understanding of this subject is based upon what he has read in official and unofficial publications. In so reading he has perused an inmense mass of misinformation, which has naturally influenced his untrained mind to conclusions so unfounded as to render all of them, except one, utterly idle and of no value.

At the outset he declares that the condition of the fur-seal herd was so bad when he saw it in July, 1906, that it can be declared to be in immediate danger of complete extermination under existing rules and regulations. Ife is right in making this statement. (Reprt on the Alaskan Fur-Seal Fishrries, by E. WV. Sims, Aug. 31, 1906, p. 3.) He asserts as an official of the Department of ('ommeree and Lahor this danger in 1906, when it was officially denied by the department in 1904, in continuation of that denial made Feloruary 7. 1902, by the Secretary of the Treasury, in reply to my charge of the existence of this danger in January, 1902, before the lifays and Means committee of the IInuse. (See hearing on fur seals, Ways and Means ('ommittee, February 18, 1902, 57 th Cong., 1st sess., pp. 7-8.)

I then furnished this committee with a detailed table of figures and facts which declared that unless the rules and regulations which governed the killing of this herd on the land and in the sea were amended the male breeding life on the fur-seal rookeries of the Pribilof Islands would be extinct by the end of the season of 1907 . (See Rept. No. 2303, Ways and Means Committee, 57th Cong., 1st sess., June 2, 1902, pp. 4, 5.)

Irr. Sims has been able in July, 1906, during his brief visit to the seal islands, to correctly grasp the truth of what I predicted in 1902, but this is the only feature of his report which will stand analysis and bear the strain successfully.

After making a brief introduction to the body of this report by a recapitulation of the physical features of the seal islands (publisherl in detail by myself, 34 years ago, in an ufficial report to the United States Treasury Department), Mr. Sims proceecls to give a résumé of the business of pelagic sealing and its license under the rules and regulations of the Bering Sea Tribunal ordered August 6, 1893 (p). 1-12). Ile then gives us a detailed account of the operations of the Japanese sealing fleet which raided the Pribilof Islands a few days before his arrival, July 20, 1906 (pp. $12-20)$.

He does not know that this raiding by Japanese hunters has been plamned and directed m these islands by (anadian and American managers ever since 1882-83. The significance of the fact that not one of these 30 or 40 Japanese hunters who landed on the island of St. Paul July 16 and 17, 1906-not one of them had a gun with him or attempted to return the fire opened on them by the United States Treasury agents, which resulted in the death of five of these hunters-the eignificance of this fact is wholly lost upon Mr. Sims. Yet he tells us incidentally that one of the Japanese (?) schooners opened a rifle fire upon the Treasury agents to cover the retreat of its hunters from the beach.

He does not know that many of these "Japanese" hunters have been raiding on these seal islands of Alaska before, and that they understood the lay of the different seal rookeries, and also the methods of the natives of the islands to guard these rookeries; that only on account of being greedy and careless were they detected this last time (July 16-17). Had they "laid off and on," as they have done since 1882-3, under the guidance of their ('anadian and American master', and kept under cover of the dene fogs so prevalent at this season (July-Sept.), annually, this raid of 1906 would have passed off as successfully as the long series of such prior raids have done, with no special ado on the part of the islander, beyond a feeble protest at the most.

He then proceeds to clescribe the need of reviaing existing law so as to cover the outlying islets of Otter, Walrus, and Sea-lion Rock, which are closely adjacent to St. Paul Island. This is, however, covered well enough by the statutes of 1868 . (Sec. 1956, Rev. Stat.)

II is recommendations as to reorganizing the Revenue-Marine-Cutter Service are idle, and of no earthly consequence, until we shall secure an agreement with Canada, which checks and prohibits pelagic sealing so as to really result in that end. This "Japanese" raid of 1906 was nothing more or less than an Anglo-American masquerade. If we secure the adhesion of Canada to a proper agreement then we will have no difficulty in getting the signatures of Japan and Russia to it; until we do get it from Canada we will never get if from Japan and Russia. 
I do not agree with Mr. Sims as to the need of enlarring the force of Government agents on the islands. One or two of the four men now provided for can always be in Washington every year from september to the following May. That is everything now required of this service. These agents are fully rlothed with all the police powers necessary, and I do not think it will amount to anything if they are enlareed as recommended; and, with regard to the work of the coast Inclians, they could get 116 information beyond the annual published reports of the London sales every December, even if they were to set about the task.

On page 27 Mr. Sims makes the recommendation that the killing of seals by Coast Inclians of Alaska should be regulated. He does not know that this regulation could not be enforced, except by such a police patrol that it would be utterly extravagant and unreasmable-indeed, nothing save the complete prohibition of pelagic sealing by white men, as well as by Indians, would compass such a regulation.

On page 27 Mr. Sims ienores without warrant the direct testimony of a trusted Russian agent of the old Russian company, who passed the entire season of 1819 (not. one week) on these Pribilof Islands, directly charged with the duty of ascertaining the cause of an anmually decreased catch on the islands. He reporterl that this derease was "rlue to the excessive killing of young male seals" by the company, and that if the same was not suspended the complete externination of the species would follow. The company took advice similar to Mr. Sims's view and ignored this intelligent warning. In 1834 that "complete extermination," predicted in 1819 by Tanovksy, touk such hold on the herd that less than 60,000 seals of all classes were left alive, and then the rompany was forced to suspend its work entirely in 18:35. There was no pelagic sealing industry even dreamed of in those days, and much less practiced; it was not a factor until 1886 .

Therefore, when Mr. Sims asserts so positively that "the decrease in sual life on the Pribilof Islands is due solely to pelagir sealing" and that this assertion of his "can not be soriously questioned," he simply comvicts himsell of being unable to understand the sense of official and authentir records of this case in hand, which deny him.

After making this unwitting confession of ignorance, he proceeds to quote the unecientific and errments uninion of the Jordan commission, which declares that nature had not wisely created the "greater part of the male life born;" that it "is superflunus ion breeding luiphses." "Ypon this unseientific and mistaken opinion Mr. Sims proceeds to reason to the end that only 1 male seal out of every 30 born, "only 1 bull in 30 is absolutely necessary under present conditions."

That $\mathrm{Mr}$. Sims, who is without training as a naturalist, and without experience of any rhasarer in handling and oluserving this fur-seal life, should accept this improper itleat the Jorlan commission is entirely natural under the rircumstances. The blunders, hoverer, of Dr. Jordan and his asoreiates have heed thomoughly exposed and

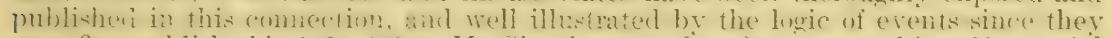

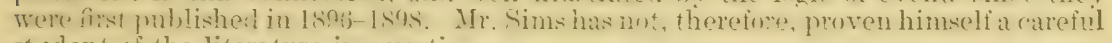
student of the literature in question.

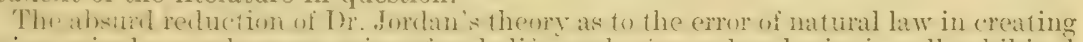

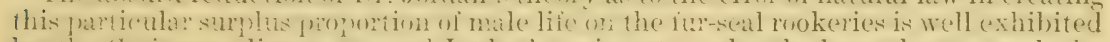

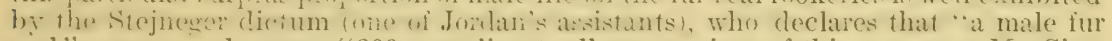
seal" can properly serve "200 cows," yet, all unconscious of this nonsense, Mr. Sims gravoly quotes Dr. stejneger, on page $2 \mathrm{~s}$, as one who spreaks authoritatively. That particular case cited by Stejneger was an example which he observed on Copper Island in 1896 ; but, by 1900, that woleery un that islated, where this immence preponderance of female life existed, was entirely extinct. Of course it was. There are abundant, full and excellent reasons for such an extinction. No real naturalist shomld harr made such a blunder as I). Stejneger has made in this vain altempt to help Dr. Jordan prove himself a law maker superior to natural cause and effect.

But. When Mr. Gims steps rlown from the riscussion of a biological question which secms to be quite beyond his understanding. like this matter of natural selection nrdered by nature to jmateres that life, and proveds to speak of the business details of "branding" and "rocerving ", 000 male seals annually" from slaughter by the Jeseces, he can not be excused from making a very grose error in statement on that point, which is fairly improper for him to make.

On page 29 he sars: "Three years ago, when it became apparent that there was a decreas in idle bulls, the department estahlished regulations wheres, : 2,000 choice 2 and 3 year old males were selered toranded, and dismised from the berd for breeding purposes before the company commeneed taking its quota for commercial purposes."

Mr. sims knows very well from the recorts, which he himself quotes, that the department did not recognize any nerd of saving these young male seals "three years ago;" he knows that this action by the department was forced on it by my showing of its necessity to the Ways and Means Committee of the House, March 9-10, 1904. 
It was denied hy the atents of the department, but Mr. F. H. IIteherek, then ehief clerk of the department, agreed with me, and then appeared hefore this committee atoresaid and inlly explained why he did so, in spite of the "scientifie" evidenee of

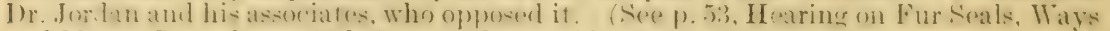
and Jeans Committee, 58th Cong., 2d sess., Mar. 9-10, 1904.)

Mr. Sins saly that 2,000 young maleseals have heen anmully "branded" in, since the season of 1904 and saved from slanghter by the lestess in compliance with this pledge given to the Ways and Means Commitiee March 9-10, 1904.

This deliberate statement of Mr. Sims is not true. These seals have not been "branded:" insteacl, they have been "sheared." The sheared marks have been put upon those seals in June and early July; they have entirely disappeared from the bodies of those seals by the middle or end of september following, since all fur seals completely shed and renew their overhair during August and September annually.

Then the significance of what follows appears to have entirely escaped Mr. Sims. It destroys completely the sense of his conclusion. The sheared seals of June and July haul out continually thereafter upon the islands during October and Norember. Each and every one of them that so appears has no longer the sheared mark upon its body. It is killed then as a "food seal," and its hide goes into the lesteres catch for the ensuing season.

Mr. Sims will find the official proof of this serious charge of inexcusable ignorance on his part, unwittingly furnished, by the very men with whom he assuciated oflicially on the e islands in 1906 . On pages 8,64 , and 65 , Senate Document No. 98, Fiftyninth congress, first session, it is officiatly stated that the use of branding irons was partly discontinued in 1904, and wholly discontinued on the seal islunds during 1905. Still more: On page 86 of this Senate Doctment No. 98 is the official declaration that these "spared" "aind sheared seals of June and July are killed on the islands as "food seals" during October and November, and so done because the sheared mark has entirely disappeared.

By this method of procedure (Mr. Sims being all unconsciois of it (?)) the leseees completely nullify the pledge given by the Department of commerce and Labor to the Ways and Means Committee, March 9-10, 1904.

Mr. Sims lats either been imposed upon by the selfish and greedy interests concerned, or else he is sadly deficient in those qualities which a ronepent investigator should possess.

With this evidence of Mr. Sims's inability to see and understand these details of the routine business as it is conducted on the seal islands, it is idle to proceed further in an extended analysis of his complete misunderstanding of it as he progresses with this report of his.

Following this erroneous statement, as above cited, made on page 2s. hy Mr. Sims, he pro: eeds to advance an irrational argument in faver of no further interference with the work of the land butchers. This improper plea for those factors of destruction is not to be serintis!y romsirlered, since it is based upon the improper aroment of Dr. D. S. Jordin, who exploited the untruth during lis96-97, that "no land killing ever injured the herd.'

The only "rational basis" upon which to kill fur seals hereatter upon the Pribilof Islands is to have it done without serving any private interest. Mr. Sims does not see anything : head but the interests of private gain, and he therefore supposes that these interests are to continue into the future as they have endured in the pest.

On paige 29. Mr. Sims says that it is not sensible or human to put the land and sea butchers out of husiness by killing off the surplus lemale and male life to a nucleus just sufficient to prescrve the species. He makes the pronounced blunder of assertion that the pelagic hunters will soon kill of this surplus female life themselves. and it is better that we continue to breed those mother seals for these butchers to kill indecently, than to decently kill them ourselves, and so mercifully end this cruel business at once.

Mr. Sims does not seem to know that when this business of the pelagie hunter is rendered impracticable by the act of killing off this surplus life at once. on the islands. at least ten years must elapse before that business can be profitably resumed. During that interval and while the pressure of these greedy private interests of land and sea butchery is thus wholly removed from the question, it will be both easy and practicable to have an agrement made with (ireat Britain, Japan, and Russia which will forever shut these hutchers out and so protect, preserve, and fully restore the fur-seal herd of Alaska.

The advice given by Mr. Sims, on page 29, that the fovernment "brand or tag all of the seals born on the islands in the same way that the great herds of cattle which roam the western prairies are branded," and that action of this kind would reduce these fur seals 10 its possession and justify it in protecting them on the high seas, is utterly impracticable and unfounded for the following good reasons, to wit [and this, too, coming from one who claims legal training]: 
First. The brand mark which might he put upun the nape, back or sicle of a fur seal would be instantly remored trom that animal s skin the the pelagic hunter in the process of skinning. the body, if its presence on that skin was conclusive evidence that it was illegally taken. In no way could such a mark be placed upon a fur seal's skin so as to prevent its perfect removal hy its "aptor as a "spear" or gumshot mark during the process of skinning.

second. The idea of attaching "metal tags" to the "young seals before they leare the islands," on which might he stamped the words. "Property of the United States"-this idea is entirely idle. The tags "an not be permanently attached to the hodies of the seals, and even if they could be so attached then this jorperty-right claim, which Mr. Sims seems to think can he made. has heen and is rendered null and void by that decision of the Bering sea tribunal. whirh on August i6, 1893, declared that no such property right could be vested in the ludies of these seals. There is no appeal from that decision, and that ends it. Yet Sims, the lawyer, does not even know it

With this puerile recommendation that the forermment proceed to lrand and tag the remmant of that fur seal herd now in existence as a means of conserving it, and making no other suggestion. Mr. Sims (loses this report hy reference to a series of statistical tables which he has compiled. There are five of these tables, duly itemized, to wit:

Table 1 is substantially correct (pp. 33-34).

Table 2 is also substantially accurate $(p .35)$

Table 3, with the discussion lhat precedes it on pages $36-37$ and following it on pages $38-11$, is. both erronems and misleading as to figures, facts, and deductions. It is wholly erroneous for the following reasons:

In attempting to get at a fair idea of the real size of the fur-seal herd in early days, and down to date, the author has assumed an arbitrary ratio of calculation based upon the annual records of seals killed. This is a ratio of " 1 to 15 , " and then he gravely" and laboriously carries it through his entire discussion as a sound and proper working hypothesis; in no sense whatever do the facts justify this ratio of " 1 to 15 , " it is utterly misleading and seli-contradicting, and it is strange that its author should soberly reduce its vagaries to cold type. Set he has done so, in spite of the fact that at frequent intervals during his discussion he admits that the " 1 to 15 ' 'ratio will not Satisfy the case and is misleading. Therefore, the appearance on page 38 of an elaborate "Table 3.-Take of skins and approximate size of seal herds, 1786-1906,' wholly hased on this ratio of " 1 to 15, " is, to $\mathrm{my}$ mind, an idle and worthless compilation with a baseless summary: indeed, it is self-confessed as such by its author.

Mr. Sims, in this table ahove cited, puts the entire number of seals on the Pribilof breeding and hauling crounds in 186 s a " "2, 000,000 ," on this arbitrary hasis of a ratio of "1 to 15 ," which governs his entire tabulation from 1786 to 1906 . The catch of fur seals made on these islands in 1868 mas 340,000 (250,000 on St. Paul and 60,000 on St. (ieorge). The sims ratio of "1 1015 " applied to this catch (precisely as he applies it to the catch of 12,886 made on both islands in 1906 ) would give $5,100,000$ seals instead of the " $2,000,000$ " which he credits the "average" of 1868 with.

1 early saw through the utter intility of makine estimates and "rough approximations" like this attempt of Mr. Siriss. 'I saw the folly of it after a few weeks' study of that life in there islands. in 1872; and, in lien of it, I made a stirvey of the herd then, which has passed into history as entirely accurate and well fominded on fact. These original charts of the precise area and location of the breeding fur-seal herd on the Pribilof Islands, as it existed there, during the seasons of $1872-1874$, are now in the posession of the State Iepartment, having been acquired by John Ifay, April 18, 1904. They declare the presence of owe 3.000 .000 of breeding seals and young, and some 1,500,000 nombreediner seals, on the Pribilof Islands, July 25, 18:2, with no increase or diminution in 1873 , and a very slight increase in 1874.

Every detail of this chiborate and carteful sirvey of the fur-seal herd has been reduced $i$ writing from my orierinal field notes and was placed in the hands of Secretary Hay, Jannary 26, 190. "There is ne "acreage extimates" in that work as Mr. Sims has eroneonsly ascertei [p. 3(i], and there is no step taken in my method of computation which his been, or r"in be criticiefel properly or schsibly, as "guesswork," even it the imaginative minc? (of Hr. Jurclan has so suggested it, and so nade it " unreliable " to Mr. Fims and kindred lightheads. He says that Jordan has "proven" it to be unreliable. (See pl). 36, 3i.) Dr. Jurdan has done nothing w the kind. Directly to the contrary. I have natede a full and complete answer to Jordan's criticisms, and that "anthority" has never been able to reply. (See p). 165s, 1679, of Congressimnal Record, February 2, l963; debate wor fur-seal bill, and passage of the same, 57 th Cong., 2d sess.)

$95100-$ No. $1-11-6$ 
The utter and soli-coniessed etror of the "complete rensuses" of the fur-seal herd made by Dr. Jordan in 1897 and by Agent Lembley in 1904 and 1905, and to which Mr. sims refors (1). 3ti), is plainly exhibited, as follows: But in justice (o) .Ir. Lembkey I want to sperify this fart, that he does not claim an "accurate count" for his figures. Ife arlmits that he is only "making an estimate," and that armission at once removes any good ground of complaint from these who hold opposite views.

The steady diminution of the herd since 1890, when my census of that seatson shower 950,000 breeding seals and young, and not to exceed 80,000 nonbreeding seals above 1 year old was such that by 1596 , when Dr. Jordan made his first appearanee on the islands, it was then not a very diflicult task to count nearly all of the breeding bulls as they planted themselves on their stations. Then, Jordan struck an average of 30 cows for each bull, and in this method of calculation he satisfied himself that some 450,000 to 480,000 breeding seals and young, exclusive of the nonbreeding seals, were then in existence. But to cover the nonbreeding seals it became necessary to fix upon some other ratio, and so the Jordan people assumed a ratio of "I to 20 ," or that for every seal taken cluring the season there were 20 seals (old and young) not taken. Thus, in 1896, the lessees by severe driving got 30,000 skins. This Jordan ratio of " 1 to 20 " would make some 600,000 seals in the herd during the season of 1896. But in 1897 the lessees took but 117,000 without exertion, and so this ratio of Jordan's assumption declared that the herd had shrivelled to 340,000 . He was suddenly aware of the gross absurdity of this great reduction, as he proceeded. to average anew that catch for $1896-97$ and apply this average to the multiple of his ratio. In this "scientific" manner did Jordan finish that portion of his "investigation," and his bad example of 1897 has set the pace for MIr. Sims in 1906, who acknowledges his indebtedness for the ill-fitting pattern of the Jordan census, and who, in turn, carries it soberly out to its idlle reduction all through the long list of killings on these Pribilof Islands since 1786 down to date. Just nonsense.

The failure of our case before the Paris tribunal was due wholly to the ignorance and the inexperience of the agents of our Government who made it up and managed it. Again, when it was reopened, in 1896-97, the ignorance and inexperience of Dr. Jordan and his associates who had charge of our case-again this deficiency on the part of our agents, resulted in making this bad matter worse, when the Jordan-Thompson "joint agreement as to matters of fact," was signed up in the Department of State, November 16, 1897.

Mr. Sims has followed this erroneous pattern of Dr. Jordan, to its absurd reduction in 1906 - "branding irons and metal tags!"

There never has been an hour since 1890 , when we first opened this question seriously with the Government of Great Britain, when we could not have settled that fur-seal question properly, had our own agents been qualified by education and experience to deal truthfully with the salient points in dispute, and honest enough to put the greedy demands of the land and sea butchers of this life down and out forever.

Lakewood, OHIO, December 9, 1906.

Henty W. Elliott.

"The President wants nothing but the facts-he will attend to nothing else, coming from anyone, no matter how close that person may be to him personally." (News item.)

BRIEF.

Analysis of the sworn official evidence which John Hay transmitted to Congress in 1902, which convicts the lessees of the Seal Islands of Alaskia of gaining their lease from the Government, on March 12, 1890, by fraud and perjury, and which is selfconfessed in this publication by those lessees aforesaid.

This proof is detailed in the testimony given to the Ways and Means Committee of the House of Representatives, by Henry W. Elliott, on January 14, 26, and 28, 1907. (Said testimony is found in the record of that fur-seal hearing given to Mr. Elliot by that committee on those dates, and duty preserved on the files.)

Respectfully submitted for the information and the use of the President by Henry W. Elliott, July 12, 1909. 


\section{EXHIBIT I.}

\section{MEMORANDUM FOR THE PRESIDENT IN RE FUR-SEAL FRAUDS.}

The evidence which has been sent in to Congress by John Hay that convicts the lessees of the seal islands of Alaska of fraud and perjury MIarch 12, 1890, in securing their lease from the Government, is found as follows:

In February, 1890, Secretary Windom invited bids for the renewal of the lease of the seal islands of Alaska, said lease to run from Mày 1, 1890, 20 years.

On February 20, in the presence of the agents and representatives of the bidders for this lease, he opened nine proposals. These bids were all carefully scheduled and referred by the Secretary to a board of survey composed of three chiefs of divisions in the Treasury Department. This board was directed to report to the Secretary the best bid offered as above stated for the Government to accept.

This board of survey found that the bid of the North American commercial Co., of San Francisco, Cal., was the best for the public, and so leported to Mr. Windom. This finding was unofficially made known to the bidders, and the Secretary informed the president of the North American ('ommercial ('o., Istar Liebses, that, on the 12th of March this loase aforesaid would be awarded to him then if he appeared at the Treasury Department at that time and complied with the stipulations and regulations demanded by law and the department.

Mr. Liebes appeared as desired and above cited. Mr. Windom then said to him that he had been credibly informed by good authority that Mr. Lieles and his associate bidders, in the name of the North American commercial Co., were owners of pelagic hunting schooners and interested in the buying and selling of fur-seal skins taken at sea. If that were true, then Mr. Windon said that he had a plain duty to perform, and would throw out the bid of the North American Commercial co.

Presiden Liebes replied that this charge that he and his associates then owned a pelagic hunting schooner or schoowers or were then interested in the buying and felling of pelagic skins was not true. He said that he and his associates had disposed of all their interests in pelagic sealing vessels and skins and came into this bidding entirely clean and free of any association with or interest in that business of pelagic sealing as charged.

Secretary Irindom then told him that he (Liebes) must make oath to that declaration; that if he did so the in this lease aforesaid would be duly awarded to the North American Commercial Co.

Mr. Liebes replied and said that he was then ready to do so: and he did so in the presence of the secretary and the several chiefs of division, who formed the Board of Surver, as above stated." This wath having been duly made and recorded, Mr. Windom then, on March 12. 1890, formally executed the lease and awarded it to the North American Commercial ('). aforesaicl. (See pl). 14')-143, H. Noc. No. 175, 54th Cong., 2d sess.)

When Mr. Isatar Liebes swore on the 1:2th day of March, 1590, that neither he nor any of his associates in the North American (oinmercial (o). orrned pelagic hunting vessels or were interested in the business of pelagic sealing. on that dar and date atoresaid he committed deliberate perjury, and $h y$ so doing he secured that lease from the Government, as above described, in a fraudulent manner.

The official sworn proof of this perjury aforesaid is found in the fulluwing: Report on the furcign relations of the United States, 1902. Appendix I, etr.. sent into Congress hy John IIay. This Appendix I is also published as House Incument No. 1, Fifty-seventh Congress, second session.

On page 203 of this liouse Incument Nu. 1 aforesaid is the sworn oflicial wath of sule ownership of the pelaure hunting schooner fumes Ifomilton L, wis, executed January 10, 1890, hy IIeman Liehes, the partner of Isaar Liebes and associate member and director of the North American Commercial Co. aforesaid.

This record of the ownership of the James Ilamitom Laris as above cited, in the name of Herman Liebes, associate incorporator, and director, of the said North American commercial co. (with Isaac Liebes, D. O. Mills, and Lloyd Tevis), stands without change on the hooks of the United States customhouse, office of the collector of the port, san Francisco, ('al., as quoted above, up to september 17,1890 . Then this 
sealing schomen, the Jumes flamilum Lemis, in mold by H. Liebes to H. Lieber de ('). (Ine.). Sis that, then, this aid vesed stants on the collector's books as the property of Herman and Isaac Liebes. (See p. 120, "Exhibit A," H. Doc. No. 1, aforesaid.)

Then and thereafter, up to July 29 . Is:31, this swom prof of the ownership of that vesesel, as above eiterl, stands without rhange; hut on this date a bill of sale is marle of that vesed by H. Liebes of (o. (Inc.) to Max ITaizman, etr. (Hee p. 120, Exhibit 1, H. Doc. No. 1, 57 th Cong., 2d sess.)

Thus the State Department, in this form and time, sends the proof clear and undisputable to ('ongress that I aac Licbe: president of the North American fommerrial ('o, of san Franciceo, Cal., did, on the 12th day of March, 1890, utter fraud and perjury in the presence of the secretary of the Treasury, Wm. Windom; that by said utterance he fraudulently secured the leate of the seal islands of Alaska, as above stated, from the Government.

\section{JULY 12, 1909.}

\section{Henry IV. Elliott.}

All of which is respectfully submitted on this 12th day of July, 1909, for the information and the use of the President of the United States.

\section{Henry IV. Elilott.}

Note. - On July 29, 1909, the President ordered this brief referred to the Department of Commerce and Labor for its information. On the 6th of August the Secretary of the Department of commeice and Labor notifies me that he has received the above and will give it consideration.

August 15, 1909.

H. W. E.

[Mailed to him, same day, 9 a. m.]

\section{To the President:}

LAKEWOOD, ОHIO, June 18, 1909.

The appended press dispatch from the Plain Dealer' this morning prompts me to ask that you call upon the chairman of the llays and Means ('ommittee of the House of Representatives for a complete copy of that testimony which I gave to his committee on January 14, 26, and 28,1907 , in re fur-seal frauds and the conduct of the lessees of the seal islands of Alaska. It has been printed, for I read all of my testimony in page revise. It has been withheld from publication-why?

This testimony aforesaid calls for the Attoney General to perform a plain duty which he is sworn to execute in the premises.

With great respect,

\section{HenRy W. ElLiott.}

\section{Hon. J. A. TAwneY,}

Washington, D. C., February 14, 1907.

House of Representatives.

On January 14 last. before the Committee on Wiays and Means, I made the distinet and specific charge of perjury and fraud against the president of the North American Commercial ('o., of Sin Francisen, and lossee of the seal islands of Alaska; sairl perjury and fraud being uttered on the 12th day of Mareh, 1890, by said president of the North American (ommercial (")., and on the "sith day of January last I submitted the sworn and official evidence which proved my charge aforesaid.

Also, on the 1.th of January last, before that committee above cited, I made the distinct and specific charge of malfeasance in office against H. H. D. Peirce, Third Assistant Secretary of State, and on the 2Sth day of January last I submitted the sworn and official evidence which proved my charge against Peirce. It is in that record of my hearing before that committee aforesaid.

If the rhairman of the Ways and Means 'ommittee does not make this testinony of mine above mentioned public, then he is vainly trying to shield those men above named, and merely deferring the date of their punishment.

Henry W. Elliott. 
Washington, D. C., February 14, $190 \%$.

DeAr Mr. Loeb: I have just been credibly informed that the chaiman of the Ways and Means Committee is not going to make public that testimony which I have placed upon the recurd of that fur-seal hearing, held in the aforesaid committec over the pending House Joint Resolution 205. The only reatson which he can assign for this unusual secrecy over such a matter which I will entertain for a moment as valid is that I have proven certain serious charges of fraud and perjury which I have made against the lessees of the seal islands of Alaska, in re securing their lase from the Government and of certain malfeasance in office against H. II. D. Peirce, Third Assistant Secretary of State, duly suborned by those agents of those lessees above cited.

While it may be best for the public interests concerned to withhold my testimony from publication at the present hour and immediate future, yet I am positive in $\mathrm{ny}^{r}$ belief that a copy of the record of this hearing above mentioned should be in the hands of the President. This fur-seal question can not be settled right without all of these facts which have been developed in committee during the progress of that hearing being known to the President.

Very sincerely, yours,

Henry W. Elliott.

WM. LoEB, Jr.,

Secretary to the President,

White House.

\section{Departaent of Commerce and Labor, \\ OfFice of the Secretary,}

Washington, August 6, 1909.

SrR: The receipt is acknowledged, by reference from the President, of your communication of 9 th ultimo, in which you make certain charges against the North A merican Commercial Co. in connection with its lease of the seal islands.

In reply you are advised that your letter and the statements contained therein will receive proper consideration.

Respectfully,

Mr. Henry W. Elliotr,

Ormsiy McHarg,

Assistant Secretary.

17 Grace Avenue, Lakewood, Ohio.

WHO ARE THESE "OFFICIALS"?-KARGER MUST TELL US.

Office of Editor Cleveland News, August 30, 1909-Monday, 9 a.m.

George 1I. Bowers shows me letter from Gus Karger to Bowers and typewritten article on yellow paper for publication, entitled "Elliottiana." In this article appeared the following ****:

"I. Secretary Nagel has instructed them (the officials of the UTnited States Fish Commission) to pay no attention to his (Elliott's) charges. * * *

"II. Elliott has made charges against James G. Blaine, John Hay, and ('harles Foster. * * * He has also made charges against Hon. John W. Foster. * * *

"III. He (Elliott) was thrown almost bodily out of the Ways and Means ('ommittee on account of getting into a controversy there with the Hon. Sereno Payne, the chair$\operatorname{man}$. * *

"IV. He used to be an authority 20 years ago, * * * but he is now getting somewhat confused. ***

"The officials of the Bureau of Fisheries have a most intense dislike for this $\operatorname{man} * * * \cdots$

This letter from Karger written in obedience to request from Bowers that Farger call on the department for some advice as to what the department was going to do in the matter of taking artion on the proof of the guilt of the lessees submitted to it by the President on July 29, 1909; said pronf given to the President on July 12, 190!), by H. W. Elliott.

Henry W. ElitotT. 
August 12, 1909

Hon. Ormsiy Mrllarg,

issistant Secretary Commerce and Labor,

Washington, $D . C$.

DE.1n Sir: Your artrice of the 6th instant that my brief of that proof which convicts the lesseres of the Seal Islands of Alaska of securing their lease by fraud and

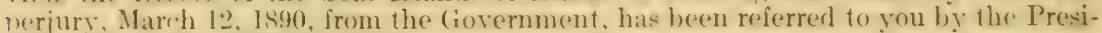
dent, has been duly received.

The best lawyers here, to whom I have submitled that proof aforesaid, all unite in saying that they fail to understand how the department (an do otherwise than promptly rancel that lease thus procured by fraud and perjury, since the evidence which corders that cancellation is so indisputably published by the United States Department of State.

Very truly, yours,

Henty W. Elliott. 


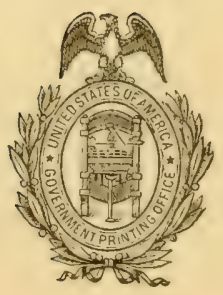







LIBRARY OF CONGRESS

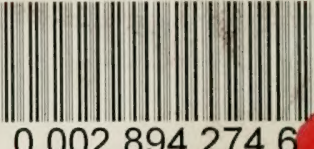

00028942746 